\title{
Current Water-Resources Activities in Ohio, 1993-94
}

Compiled by S.M. Hindall and R.P. Frehs

United States Geological Survey

Open-File Report 93-458

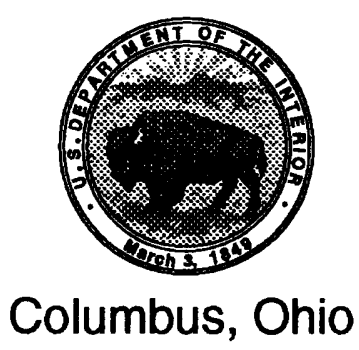

1993 


\section{U.S. DEPARTMENT OF THE INTERIOR BRUCE BABBITT, Secretary}

\section{U.S. GEOLOGICAL SURVEY}

ROBERT M. HIRSCH, Acting, Director

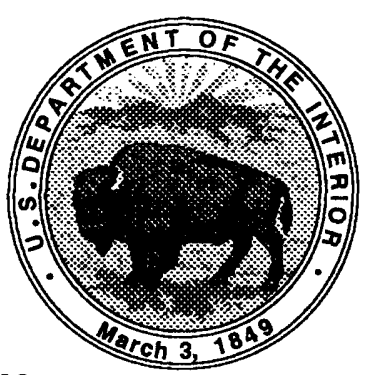

Any use of trade names in this publication is for descriptive purposes only and does not imply endorsement by the U.S. Geological Survey.

UNITED STATES GOVERNMENT PRINTING OFFICE: 1993

Copies of this report may be purchased from:

U.S. Geological Survey Earth Science Information Center

Open-File Reports Section

Box 25286, MS 517

Denver Federal Center

Denver, CO 80225

Library of Congress Cataloging in Publication Data 


\section{FOREWORD}

The U.S. Geological Survey, Water Resources Division, has been active in waterresources investigations in Ohio for more than 70 years. During that time, volumes of data have been collected, numerous investigations have been completed, and more than 150 reports have been published on various aspects of Ohio's water resources. Many changes have taken place in the Geological Survey and the Water Resources Division since its formation in 1879 , but our mission remains firm-"to provide the hydrologic information and understanding needed for the optimum utilization and management of the Nation's water resources for the overall benefit of the people of the United States." As the water resources of Ohio become increasingly important to its economy and quality of life, the Ohio District's role as an unbiased water-resources investigation and data-collection agency also becomes increasingly important.

Over the years, the District's programs have reflected the needs of the people and the priority issues of the times. We have evolved from the early days of hydrologic data collection and ground-water and surface-water reconnaissance studies into flood and low-flow studies, projects associated with energy production, and, finally, into studies relating to hazardous-waste disposal and ground-water contamination. The District continues to move into new areas of water resources previously not studied by our scientists. Those areas are: (1) agricultural contamination of ground water and surface water, (2) bridge scour, and (3) microbiological and bacterial research and assessments. Through all of this, the District has continued to expend a considerable amount of its resources in collecting and disseminating basic data on surface water, ground water, and sediment.

Our present program centers on five areas: basic hydrologic data collection and geohydrological, environmental, hydrological, water-quality, and ecological studies. Of the five, the basic hydrologic data-collection effort is the largest in terms of employees involved, whereas the environmental studies is the largest in terms of funds expended. In all of the above areas, chemical quality of the resources is an important factor. This is evidenced by the rapid growth of new projects in the area of water quality and aquatic biology and microbiology as it relates to ground-water and surface-water systems. In fact, water quality will most likely become the overriding concern in all water-resources investigations well into the 1990's and beyond. The use of computers and digital modeling will continue to be an integral part of all investigations.

The Ohio District has become involved with the U.S. Department of Defense at Wright-Patterson Air Force Base in water-resources data-collection assessments and applied research. We are also in the process of expanding our programs with the U.S. Environmental Protection Agency with regard to their Superfund site activities. We look forward to the U.S. Geological Survey's active role in these activities and to a continuing relationship with state, county, local, and other Federal agencies in studying and addressing water-resources concerns and issues in Ohio. 
Nationally, the Water Resources Division has recently embarked on a far-reaching activity - the implementation of a full-scale National Water-Quality Assessment program (NAWQA). The goals of the NAWQA program are to provide a nationally consistent description of current water-quality conditions for a large part of the Nation's water resources; to define long-term trends (or lack of trends) in water quality; and to identify, describe, and explain the major factors that affect observed water-quality conditions and trends. Of the 60 proposed study units, 20 began in Federal fiscal year 1991, and an additional 20 will follow in fiscal year 1994. In Ohio the Lake St. Clair drainage has been selected to begin in 1994 and the Great Miami/Little Miami drainage for 1997.

The Water Resources Division completed a divisionwide reorganization designed to increase Districts' abilities to meet the needs of cooperating agencies and respond to changing water-resources issues. A major component of the reorganization was the formation of 19 program areas within the four existing regions. The Ohio District was joined by the Kentucky and Indiana Districts to form the Ohio Program Area. Slight modifications of the boundaries of the existing four regions were made. The Northeastern Region (Ohio's region) was divided into five areas. The individual district structure or the way in which the districts deal with cooperating agencies has not and will not change. It is hoped that the subregional reorganization will result in increased efficiency of operation and improvement of the quality of technical programs.

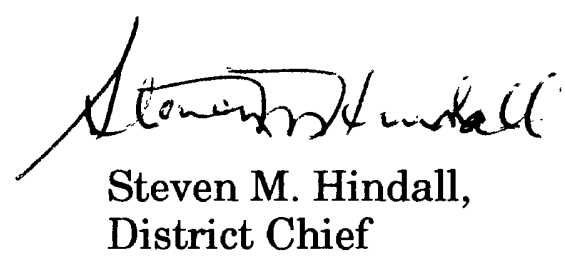




\section{CONTENT}

Page

Foreword iii

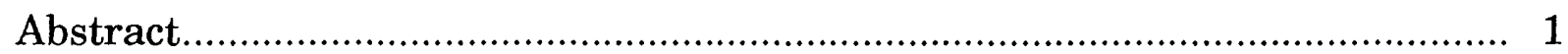

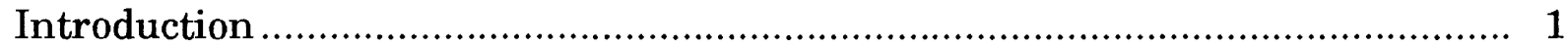

Basic mission and program of the Water Resources Division .................... 3

Operation of the Ohio District ............................................................... 4

Summary of water conditions in Ohio ................................................ 7

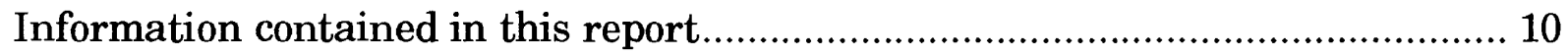

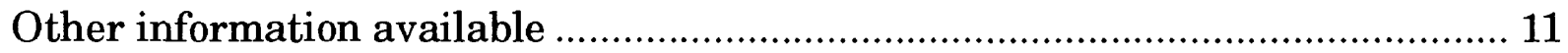

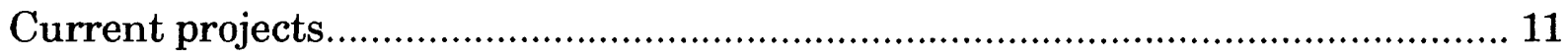

Surface-water stations for which records are published .................................... 40

Ground-water stations for which records are published .................................. 49

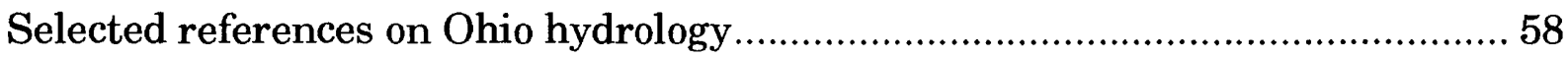

\section{ILLUSTRATIONS}

Figure 1. Map showing average discharge of principle streams in Ohio

2. Map showing the geographic distribution of principal aquifers in Ohio 


\title{
CURRENT WATER-RESOURCES ACTIVITIES IN OHIO, 1993-94
}

\author{
Compiled by S. M. Hindall and R. P. Frehs
}

\section{ABSTRACT}

The mission of the U.S. Geological Survey's Water Resources Division is to provide the hydrologic information and understanding needed for the optimum utilization and management of the Nation's water resources for the overall benefit of the United States. This report summarizes the Division's program in Ohio in 1993-94.

The work of the Ohio District is carried out through the district office in Columbus and a field office in New Philadelphia. Collection of the basic data needed for continuing determination and evaluation of the quantity, quality, and use of Ohio's water resources is the responsibility of the district's Hydrologic Surveillance and Information Management Section. The Hydrologic Investigation and Program Development Section conducts analytical and interpretive water-resources appraisals describing the occurrence, availability, physical, chemical, and biological characteristics of surface water and precipitation. The Geohydrologic and Environmental Investigation Section conducts similar appraisals associated with ground water. In addition, the U.S. Department Of Defense and U.S. Environmental Protection Agency programs are the responsibility of this section.

In addition to introductory material describing the structure of the Ohio District, information is presented on current projects, sites at which basic surface-water and ground-water data are collected, and reports on Ohio's water resources published by the U.S. Geological Survey and cooperating agencies.

\section{INTRODUCTION}

The U.S. Geological Survey was established by an act of Congress on March 3, 1879 , to provide a permanent Federal agency to conduct the systematic and scientific "classification of the public lands, and examination of the geological structure, mineral resources, and products of national domain." An integral part of that original mission includes publishing and disseminating the earth-science information needed to understand, to plan the use of, and to manage the Nation's energy, land, mineral, and water resources.

Since 1879, the research and fact-finding role of the Survey has evolved to meet the changing needs of the Nation it serves. As part of that evolution, the Survey has become the Federal government's largest earth-science research agency, the Nation's largest civilian map-making agency, the primary source of data on the Nation's surfacewater and ground-water resources, and the employer of the largest number of professional earth scientists. 
Today's programs serve a diversity of needs and users. Programs include:

- Conducting detailed assessments of energy and mineral potential of the Nation's land and offshore areas.

- Investigating and issuing warnings of earthquakes, volcanic eruptions, landslides, and other geologic and hydrologic hazards.

- Conducting research on the geologic structure of the Nation.

- Studying the geologic features, structure, processes, and history of the other planets of our solar system.

- Conducting topographic surveys of the Nation and preparing topographic and thematic maps and related cartographic products.

- Developing and producing digital cartographic data bases and products.

- Collecting data on a routine basis to determine the quantity, quality, and use of surface water and ground water.

- Conducting water-resources appraisals to describe the consequences of alternative plans for developing land and water resources.

- Conducting research in hydraulics and hydrology, and coordinating all Federal water-data acquisition.

- Using remotely sensed data to develop new cartographic, geologic, and hydrologic research techniques for natural-resources planning and management.

- Providing earth-science information through an extensive publications program and a network of public-access points.

Along with its continuing commitment to meet the growing and changing earthscience needs of the Nation, the Survey remains dedicated to its original mission to collect, analyze, interpret, publish, and disseminate information about the natural resources of the Nation-providing "Earth Science in the Public Service." 
Basic Mission and Program of the Water Resources Division

The mission of the Water Resources Division is to provide the hydrologic information and understanding needed for the optimum utilization and management of the Nation's water resources for the overall benefit of the people of the United States.

This is accomplished, in large part, through cooperation with other Federal and non-Federal agencies by:

- Collecting on a systematic basis data needed for the continuing determination and evaluation of the quantity, quality, and use of the Nation's water resources.

- Conducting analytical and interpretive water-resources appraisals describing the occurrence, availability, and the physical, chemical, and biological characteristics of surface water and ground water.

- Conducting supportive basic and problem-oriented research in hydraulics, hydrology, and related fields of science to improve the scientific basis for investigations and measurement techniques and to understand hydrologic systems sufficiently well to quantitatively predict their response to stress, either natural or man made.

- Disseminating the water data and the results of these investigations and research through reports, maps, computerized information services, and other forms of public releases.

- Coordinating the activities of Federal agencies in the acquisition of water data for streams, lakes, reservoirs, estuaries, and ground waters.

- Providing scientific and technical assistance in hydrologic fields to other Federal, State, and local agencies, to licensees of the Federal Power Commission, and to international agencies on behalf of the Department of State.

- Acquiring, developing, and disseminating information on water-related natural hazards such as droughts, floods, landslides, land subsidence, mudflows, and volcanoes.

- Administering the provisions of the Water Resources Research Act of 1984, which include the State Water Resources Research Institutes and the Research Grants and Contracts Programs.

- Supporting the provisions of the National Environmental Policy Act of 1969 and managing the Geological Survey conduct of natural-resources surveys in response to the Comprehensive Environmental Response, Compensation, and Liability Act (Superfund Act) of 1980. 


\section{Operation of the Ohio District}

The Ohio District is part of the U.S. Department of the Interior, Geological Survey, Water Resources Division. There are a total of 47 districts: each State is a district except for four States (Delaware, Rhode Island, New Hampshire, and Vermont), which are parts of other districts. Recent Water Resources Division reorganization further grouped the 47 districts into 13 areas within 4 major regions. Ohio, Indiana, and Kentucky constitute the Ohio Valley Program Area.

The Ohio District consists of the district office in Columbus and a field office in New Philadelphia. There are three major sections in the district office-Hydrologic Investigation and Program Development, Hydrologic Surveillance and Information Management, and Geohydrologic and Environmental Investigation Sections. The New Philadelphia field office is part of the Hydrologic Surveillance and Information Management Section.

Steven M. Hindall, District Chief, is responsible for the overall operation and management of the district and is assisted by the Assistant District Chief, Richard V. Swisshelm, Jr., and Section Chiefs, Harold L. Shindel and Jeffrey T. de Roche. To carry out the diversity of tasks in support of its varied program, the Ohio District's 66-member staff consists of administrative, clerical, and support personnel.

The chart on the following page depicts the organization of the Ohio District and explains the functions of the individual sections and units within those sections.

Funds to support the work performed by the Ohio District, Water Resources Division, are derived from three principal sources:

- Federal Program-Funds for the Federal Program are appropriated by Congress, and are. specifically identified in the annual Geological Survey budget. These funds are used to support research, data collection, high-priority topical programs including Regional Aquifer Systems Analysis (RASA), National Water Quality Assessment program (NAWQA), climate research, coordination of all Federal programs related to collection of water data, and internal support services.

- Federal-State Cooperative Program-Federal funds are appropriated by Congress and used to match those furnished by State and other tax-supported agencies. These funds are used for a variety of hydrologic data-collection activities and water-resources investigations in which the Water Resources Division represents the national responsibilities and the cooperating agencies represent State and local interests.

- Other Federal Agencies (OFA) Program-In this program, the funds are transferred to the Geological Survey as reimbursement for work performed at the request of another Federal agency. 


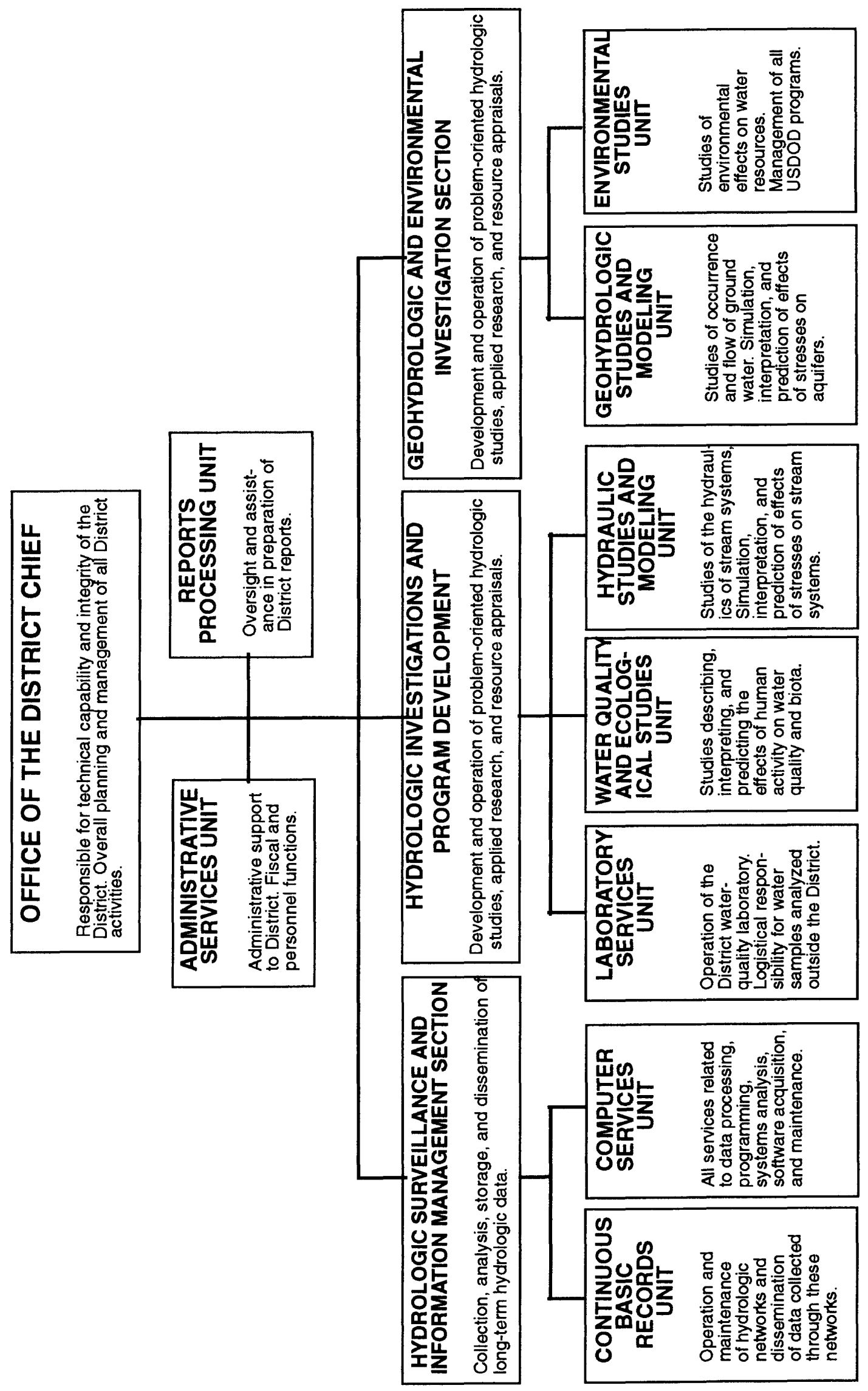


The diagram below shows the percentage of the district's projects for fiscal 1993 in each of the broad program categories of hydrologic data collection, water quality and ecological studies, hydraulic and modeling studies, geohydrologic studies, and environmental studies.

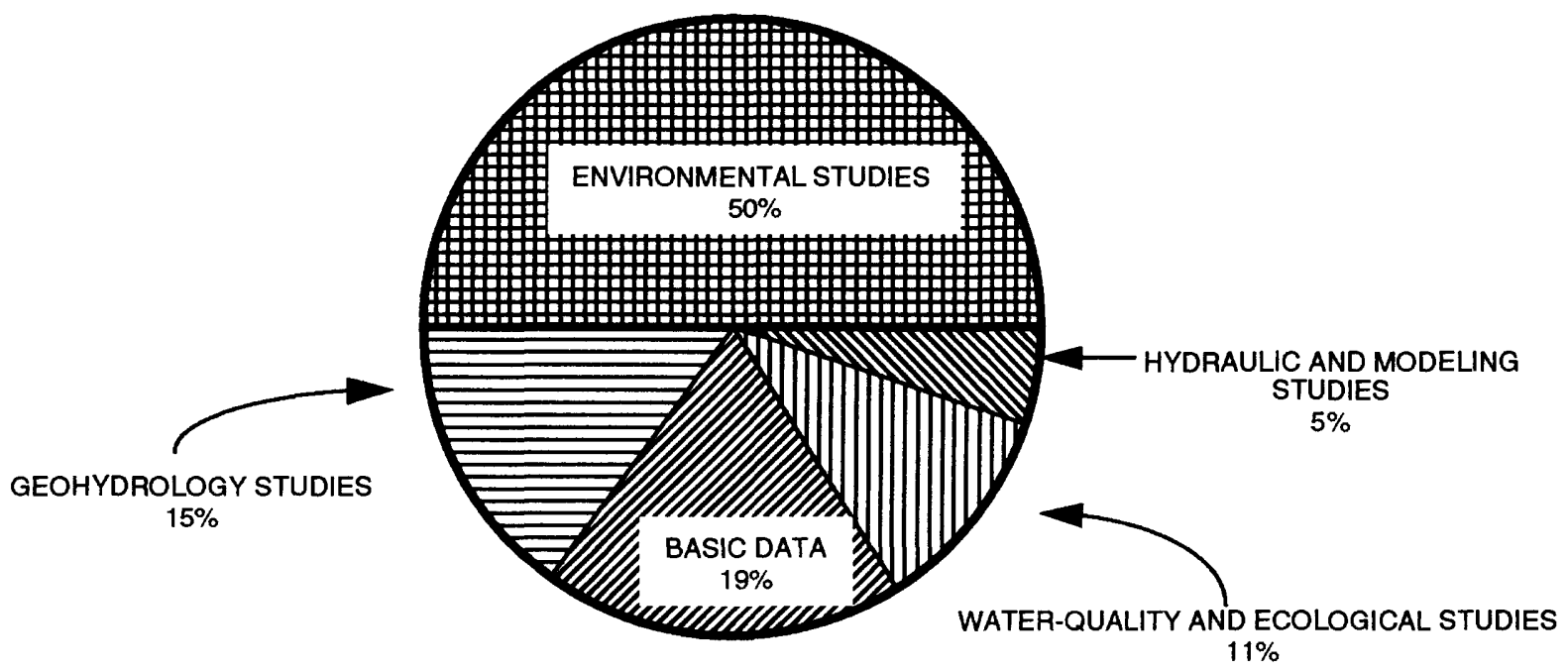

The programs are supported by funds provided by State and local units of government and Federal funds from the U.S. Geological Survey and other Federal agencies (OFA program). About 65 percent of the funds contributed by the Geological Survey are matched funds contributed by State and other local units of government. In fiscal year 1993, the total financial support for all programs in Ohio is about $\$ 6.1$ million and is distributed as follows:

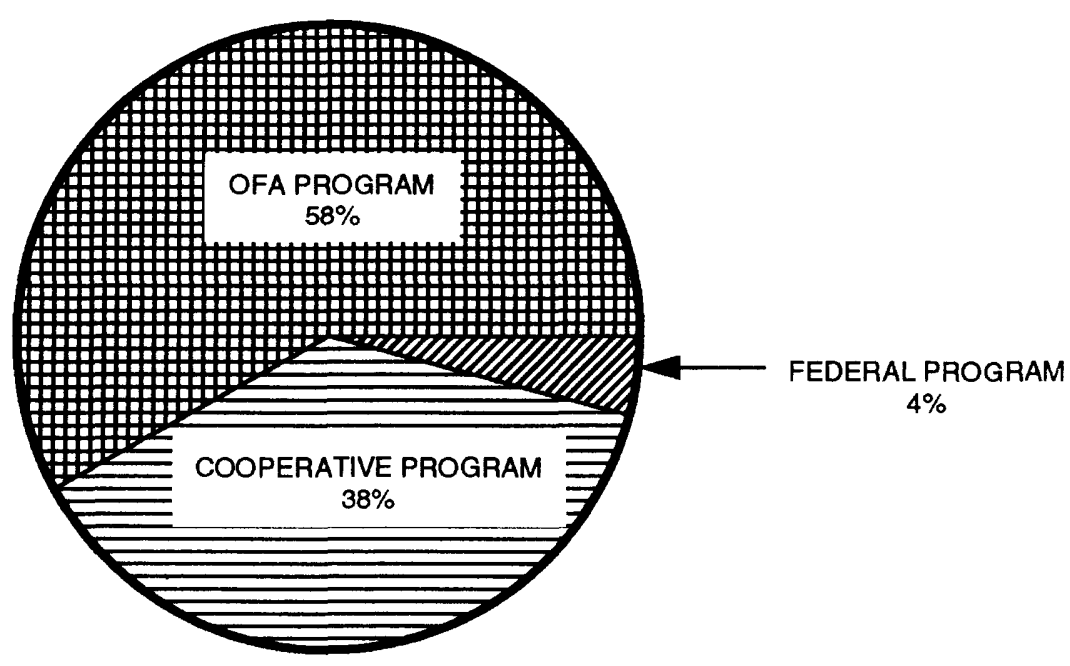




\section{Summary of Water Conditions in Ohio}

The availability of water has been an important factor in Ohio's development. Ohio's principal streams (fig. 1) were the settlers' first avenues of transportation and their first sources of power for manufacturing. Shallow, hand-dug wells provided water to a growing farm population. The construction of canals beginning in 1825 continued to encourage the growth of cities and industries and to stimulate agricultural production. Today, Ohio is still characterized by a diverse economy in which water resources play a vital part.

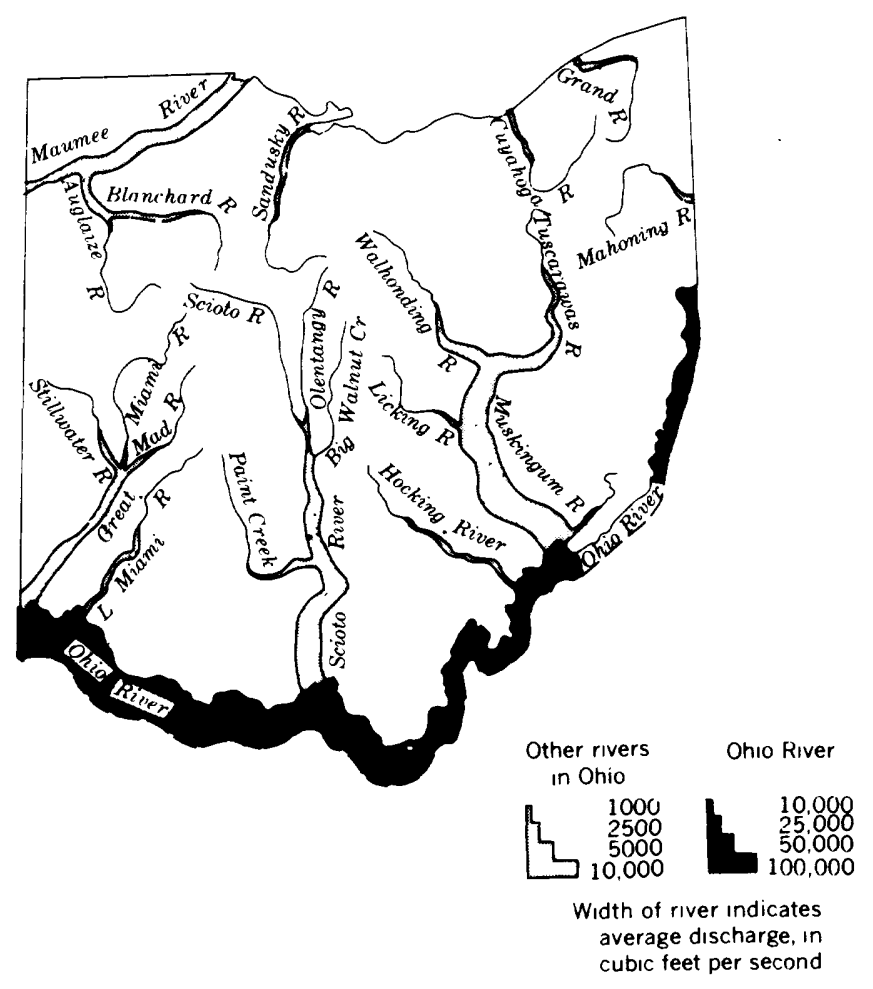

Figure 1.-Average discharge of principle streams in Ohio. 
Ohio receives about 38 inches of precipitation annually. About 10 inches runs off immediately, 2 inches is retained at or near the surface and evaporates or transpires, and 26 inches enters the ground. Of the 26 inches that enters the ground, 20 inches is retained in the unsaturated zone and is later lost by evapotranspiration. The remaining 6 inches reaches the water table. Of this 6 inches, 2 inches is eventually discharged to streams, and the rest is lost by evapotranspiration or consumptive use.

Ohio's water problems tend to be localized. Generally, these problems involve excess water (flooding or poor drainage) or water quality. Nonpoint source (NPS) contamination of surface water and ground water is becoming a significant problem in Ohio as more is being learned of the effects of NPS on water-resource systems.

Serious local flooding occurs in Ohio nearly every year. Most Ohio floods are either flash floods resulting from intense summer thunderstorms or large-stream floods resulting from a combination of rain and snowmelt. Accelerated erosion of bare ground and stream banks and deposition of sediment in stream channels, culverts, and drainage ditches are negative side effects of flooding. Eight projects are active in the Ohio District, in fiscal year 1993, that directly or indirectly contribute to our knowledge of flooding and (or) related sedimentation problems in the State.

The focus of concern about Ohio's water quality in recent years has been on waste disposal and its effects on ground-water quality. Despite the predominance of surface water in terms of total withdrawal, the importance of ground water to Ohio cannot be overlooked. Nearly 80 percent of the public water-supply systems in the State depends to some extent on ground water as a source, and 42 percent of the Ohio population uses ground water as their primary supply. The principle aquifers in Ohio are the unconsolidated deposits of coarse- or fine-grained sediments and sedimentary rocks of shaley sandstone and (or) limestone (carbonate). Geographic distribution of the principle aquifers in Ohio is shown in figure 2. 


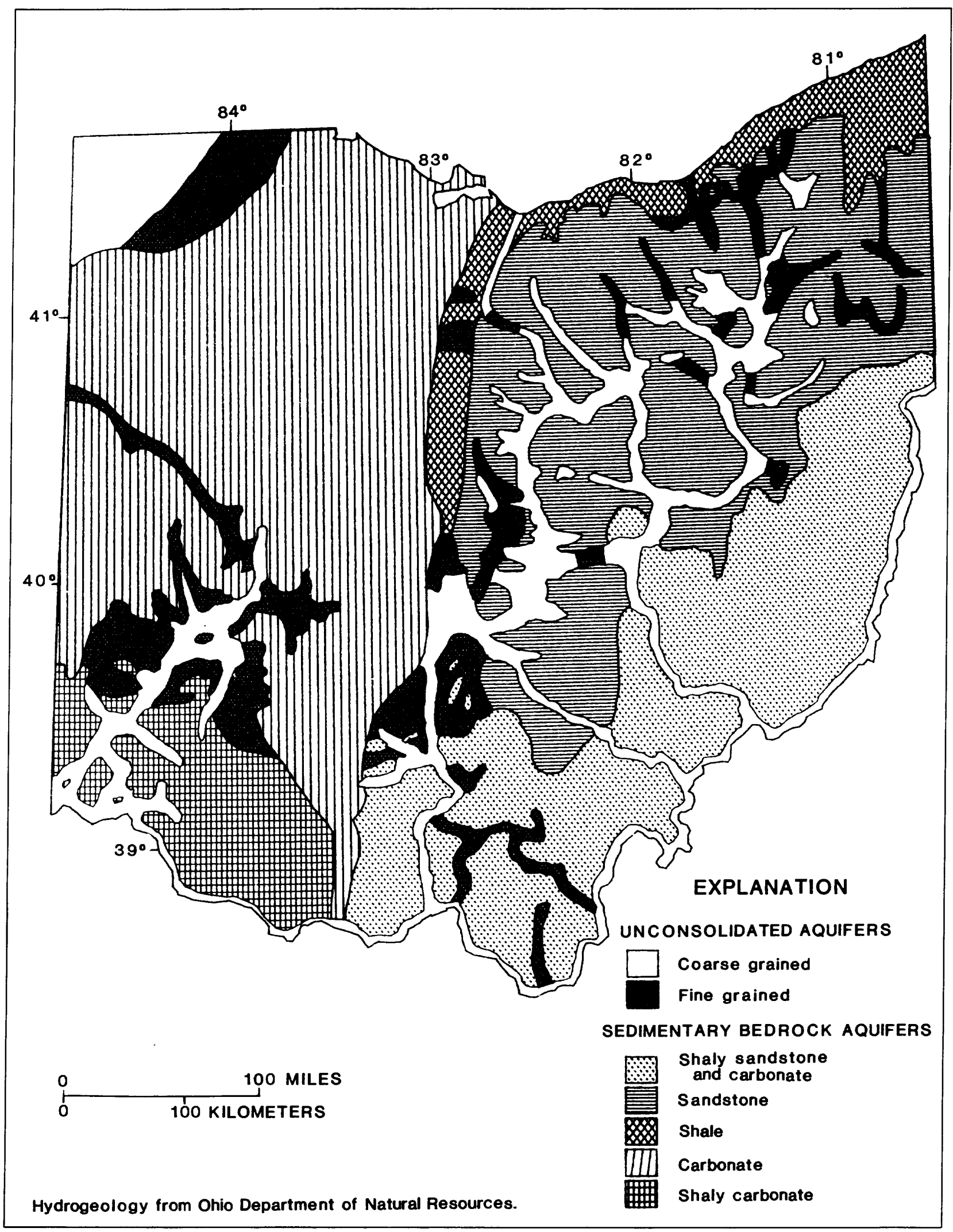

Figure 2.--Geographic distribution of principal aquifers in Ohio. 


\title{
INFORMATION CONTAINED IN THIS REPORT
}

Information is presented in the remainder of this report in four parts: (1) A listing and brief description of current projects, (2) a listing of surface-water hydrologic data stations, (3) a listing of ground-water hydrologic-data stations, and (4) selected references on Ohio hydrology. The first part contains information on the status of all projects in which there has been activity during 1993. Further information concerning project activities is available from the project leader or from Richard V.

Swisshelm, Jr. The second and third parts contain tables showing station numbers, station names, and types of data collected. Further information on statewide station activities, unpublished records, or provisional data prior to publication is available from Harold L. Shindel. The fourth part is a selected list of reports issued by the U.S. Geological Survey and its cooperating agencies concerning hydrologic investigations in Ohio. Further information on these reports is available from the Information Officer for the Ohio District.

These contact people can be reached at

Water Resources Division

U.S. Geological Survey

$975 \mathrm{~W}$. Third Avenue

Columbus, $\mathrm{OH} 43212$

(614) 469-5553

Additional Information about data-collection activities in northeastern Ohio can be obtained by contacting

\author{
Lowell Trimble \\ New Philadelphia Field Office \\ Water Resources Division \\ U.S. Geological Survey \\ 551 Wabash Avenue, P.O. Box 272
}

New Philadelphia, OH 44663

(216) 343-2343 


\section{OTHER INFORMATION AVAILABLE}

The U.S. Geological Survey publishes an annual series of reports titled "Water Resources Data-Ohio, volume 1 and 2" in which the hydrologic data collected during each water year are presented. Information about these reports and how to obtain them is available from the district office at the address and phone number given on the previous page.

Flood-prone area maps for selected parts of Ohio also are available from the district office. These maps were prepared in cooperation with the U.S. Department of Housing and Urban Development, Federal Insurance Administration, to serve as guides for public agencies and private citizens concerned with present and future land development. The maps were prepared on standard 7-1/2 minute topographic quadrangles and show the approximate area subject to inundation by a 100 -year flood.

The Ohio District does not sell the standard 7-1/2 minute topographic maps of Ohio. These maps may be purchased from:

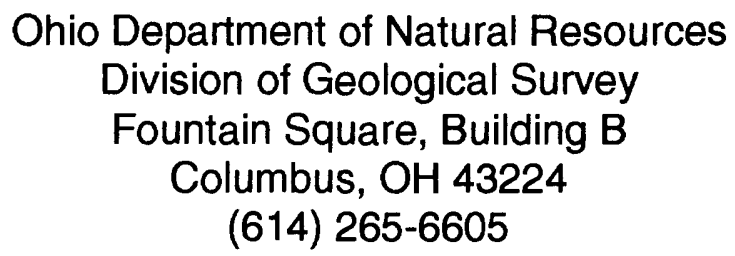

To order topographic, hydrologic, geologic, land-use, and land-cover maps, and map indexes for other states published by the USGS, contact:

USGS Map Distribution

Box 25286, Building 810

Denver Federal Center

Denver, CO 80225

(303) 236-7477

\section{CURRENT PROJECTS}

The project descriptions that follow show project title and number, period of project, project leader, cooperating agencies, purpose of project, and progress and significant results. 


\section{Period of Project:}

Continuous since October 1915

\section{Project Leader:}

Harold L. Shindel

\section{Cooperators:}

Ohio Department of Natural Resources

City of Columbus

Miami Conservancy District

Ohio Environmental Protection Agency

City of Canton

U.S. Army Corps of Engineers

Seneca Soil and Water District

Ross County

City of Fremont

Toledo Metropolitan Area Council of

Governments

University of Cincinnati

Eastgate Development

City of Lima

City of Akron

U.S. Department of Energy

Purpose: Provides a surfacewater data base through collection, analysis, and publication of records for streamflow-gaging stations and selected sites along streams, lakes, and reservoirs throughout Ohio. The gagingstation network is operated in cooperation with other Federal, State, and local agencies. The surface-water data base provides information for research purposes of surveillance, planning, design, hazards warning, accounting systems, operation, and management in various water-related fields.

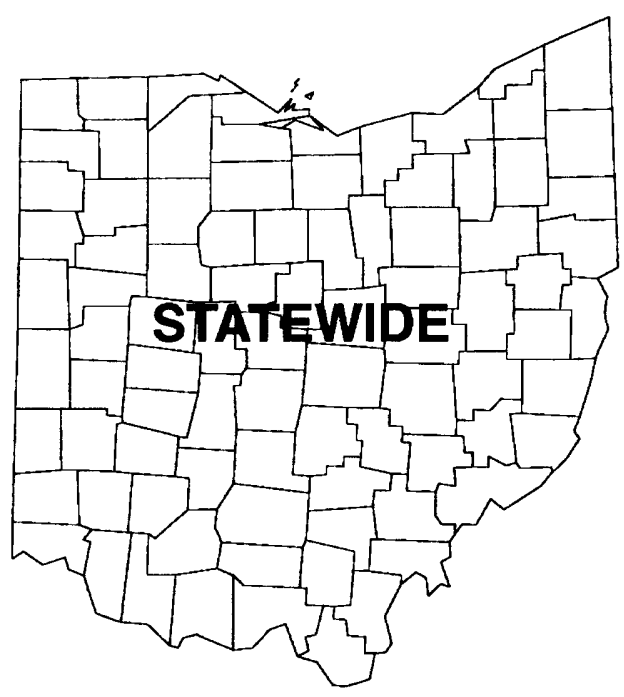

Progress and significant

results: Field data were collected on schedule and prepared for publication (water year 1992) as "U.S. Geological Survey, Water Resources Data-Ohio, 1992, volumes 1 and 2." Network maintenance was continued, including modernization of equipment at selected sites to improve record quality. Modifications to the network, such as additions or deletions of stations or data-collection activity, were made in response to program needs. 


\section{GROUND-WATER STATIONS \\ (OH002)}

\section{Period of Project:}

Continuous since January 1938

\section{Project Leader:}

Stephen A. Vivian

\section{Cooperator:}

Ohio Department of Natural Resources

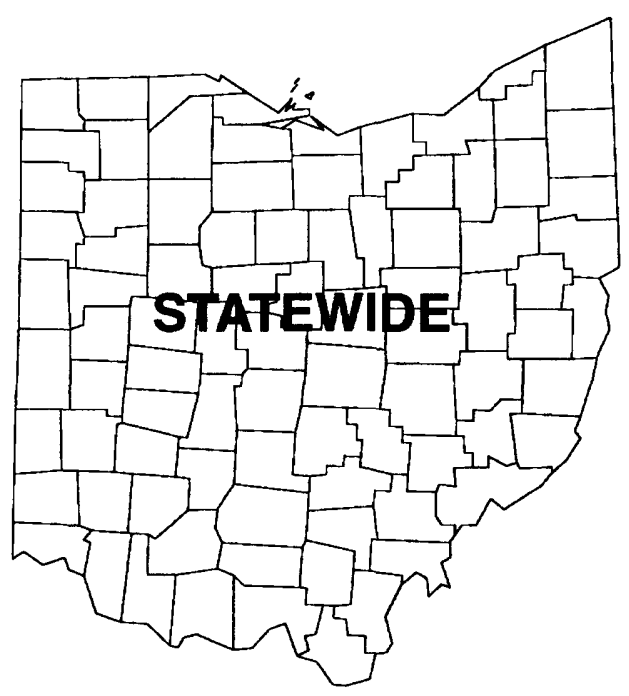

Purpose: Observe the effects on ground-water quantity and quality exerted by such factors as climate variations and withdrawal patterns. Waterlevel data are collected to provide a data base against which scientists and waterresources managers can compare short and long-term fluctuations.

\section{Progress and significant}

results: Field data were collected and processed on schedule for annual report publication. The network currently consists of 102 State-operated sites instrumented with continuous recorders and 11 sites at which periodic measurements are made. 


\section{WATER-QUALITY STATIONS}

(OH003)

Period of Project:

Continuous since January 1946

Project Leader:

Charles N. Owens

\section{Cooperators:}

Miami Conservancy District

Ohio Environmental Protection Agency

Purpose: Collect, analyze, and publish water-quality records for selected sites in Ohio in cooperation with State and local agencies. The records contribute to a national waterquality data base requisite to national and regional planning and action programs.

\section{Progress and significant} results: Surface-water stations operated by the U.S. Geological Survey consist of eight NASQAN stations and one Benchmark station in the water-quality network in water year 1993. Four Miami Conservancy District groundwater sites also were sampled. The Geological Survey collects a water sample at the NASQAN sites for the Ohio Environmental Protection Agency for the determination of chemical oxygen demand. Data for water year 1992 were published in the annual report.
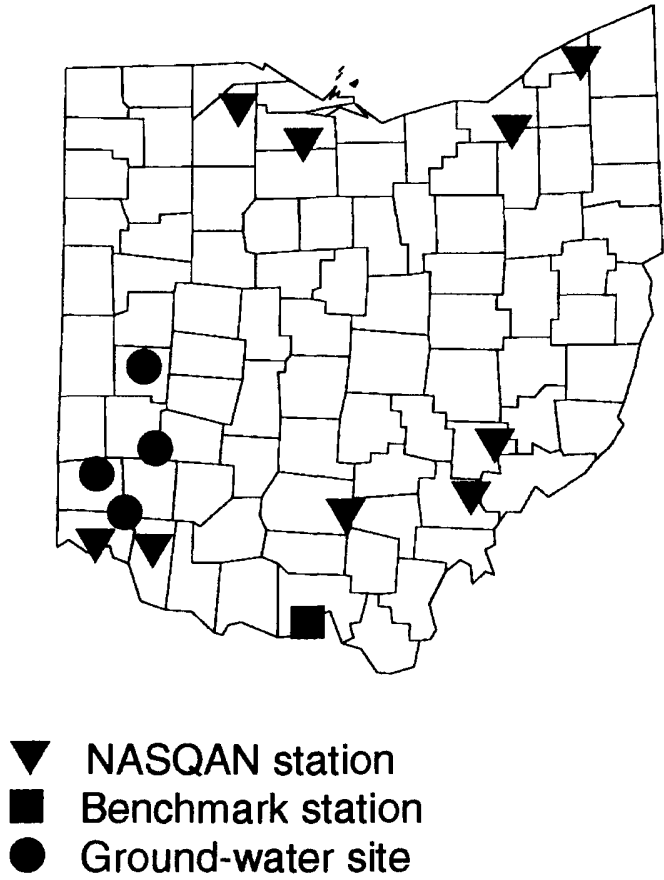


\section{SEDIMENT STATIONS}

(OH004)

Period of Project:

Continuous since July 1970

\section{Project leader:}

John W. Roberts

\section{Cooperator:}

Ohio Department of Natural Resources

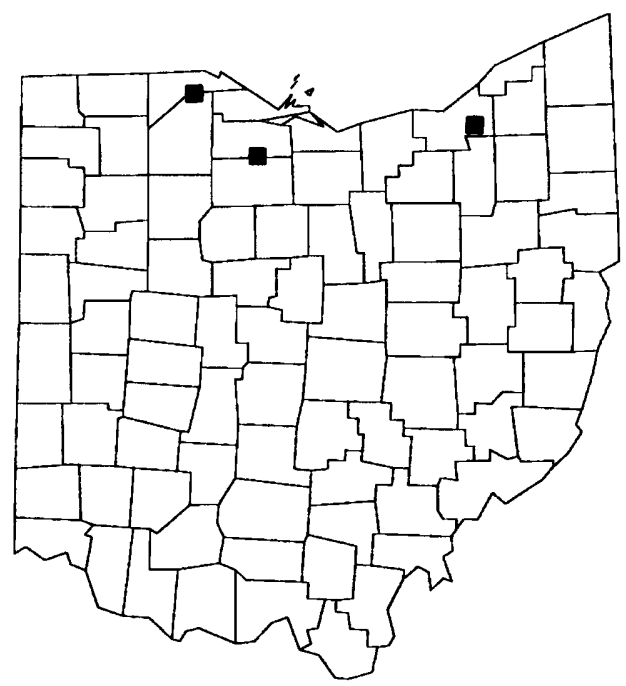

Purpose: Provide a data base needed to assess sedimentation characteristics of drainage areas required for planning and management of State and Federal programs. The data also are needed to evaluate effectiveness of Ohio House Bill 513, which concerns the abatement of sediment loading in agricultural and urban situations.

\section{Progress and significant}

results: A network of three daily sediment stations is being operated to provide spatial and temporal averages of concentration, discharge, and particlesize distribution of suspended sediment carried by a major stream tributary to Lake Erie. All 1992 data were collected and processed on schedule for publication in the annual report. 


\section{FLOOD INVESTIGATIONS}

\section{(OHO06)}

Period of Project:

March 1984 (reestablished) through

February 1993

\section{Project leader:}

K. Scott Jackson

\section{Cooperator:}

Federal Emergency Management Agency (FEMA)

Purpose: Conduct the necessary hydrologic and hydraulic evaluations and studies of areas assigned by the Federal Emergency Management Agency (FEMA) and to present the results in an appropriate format. The National Flood Insurance Act of 1968 and the Flood Disaster Protection Act of 1973 provide for the operation of a floodinsurance program. Flood studies in selected areas are needed by FEMA to determine applicable flood-insurance premium rates.

\section{Progress and significant} results: Work has been completed on FEMA-Flood Insurance Agency Type 15 flood-insurance studies at Crooksville, Perry County, and London, Madison County, Ohio. Nineteen Limited-Detail Studies have been completed: St. Marys, Auglaize County; Darbyville, Pickway County; Jewett, Harrison County; Amesville, Athens County; Middlefield, Geauga County; Jeffersonville, Fayette County; Belle Valley, Noble County;

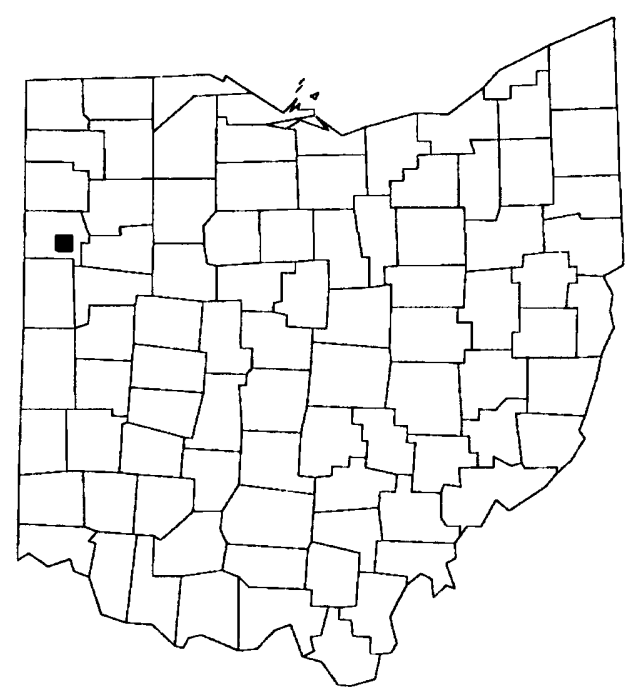

Sabina, Clinton County; Lynchburg, Highland County; Hamden, Vinton County; Salineville, Columbiana County; Coalton, Jackson County; Rutland, Meigs County; Roseville, Perry County; Westerville, Franklin County; Pickerington, Fairfield County; Montgomery, Hamilton County; Louisville, Stark County; and Powell, Delaware County. One Limited-Map Maintenance Program restudy, for the community of Reynoldsburg, Franklin, Licking, and Fairfield Counties, has been completed. A restudy of Paulding County is in progress. 
Period of Project:

Continuous since October 1977

\section{Project Leader:}

Vance E. Nichols

\section{Cooperator:}

Ohio Department of Natural Resources

Purpose: Establish an effective and coordinated program for collecting, storing, accessing, and disseminating water-use data. The data are organized to be compatible with a National data base for water use. In Ohio, there is a demonstrated need for local and statewide water-use information that is consistent with regard to definitions, standards, and methods of presentation.

\section{Progress and significant} results: U.S. Geological Survey Circular 1081, 1990 Estimated WaterUse Data for the United States; OpenFile Report 92-63, Preliminary Estimates of Water Use in the United States, 1990; and a Fact Sheet titled Estimated Wàter Use in Ohio, 1990 Public-Supply Data were published recently. A microcomputer data base, developed in cooperation with the Ohio Department of Natural Resources, Division of Water, is installed at the Division of Water to store and organize data on water users who use

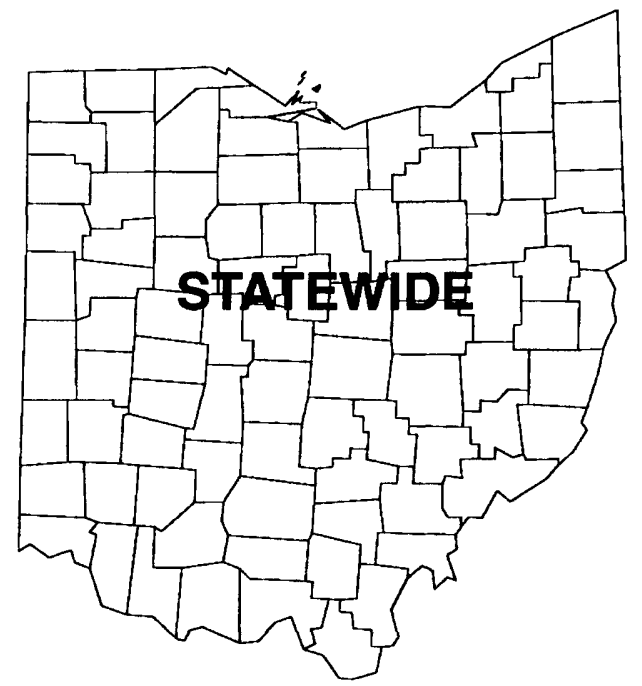

100,000 gallons per day or more (reporting of water use of 100,000 gallons per day or more is now required by State law).

Public-water-supply, commercial, and industrial data continue to be entered into the National Water Inventory System's Site Specific Water Use Data System data base on the District's computer system. Quality-assurance and quality-control evaluation of the entered data also continues. 


\section{HYDRAULICS OF RIVER VALLEYS AND BRIDGE SITES (OH010)}

Period of Project:

Continuous since June 1963

Project Leader:

G.F. Koltun

\section{Cooperator:}

Ohio Department of Transportation

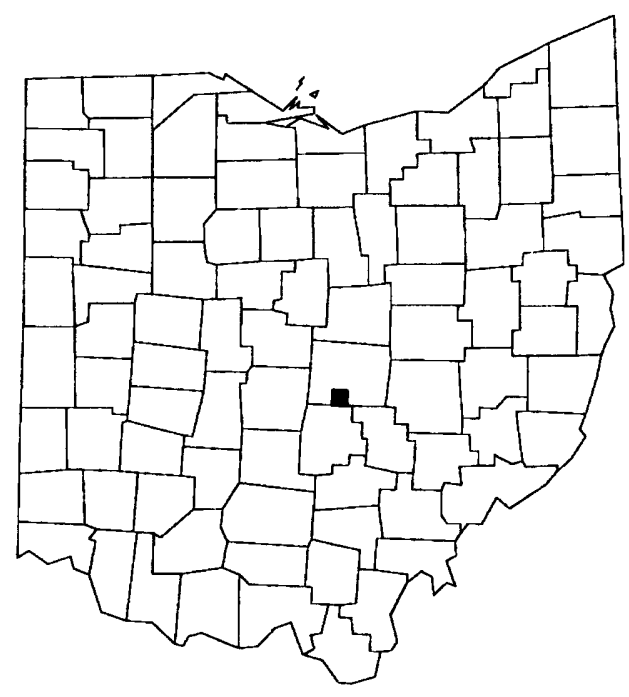

Purpose: Evaluate the hydraulic effects of proposed or existing bridges and highway fills at selected locations. Such structures can decrease the capacity of river valleys for conveying floodwaters and, in turn, could cause backwater and excessive upstream flooding. This project also provides information to highway engineers on miscellaneous hydrologic topics related to the design or maintenance of highway properties.

\section{Progress and significant}

results: Monitoring of discharge from conventional sand-and-gravel-fill and geotextile longitudinal highway drains continues. The conventional drain generally exhibits the quicker, more peaked response after a storm; however, a greater volume of water discharges from the geotextile drain over time. 


\section{AUTOMATIC MEASUREMENT OF TEMPERATURE, SPECIFIC CONDUCTANCE, DISSOLVED OXYGEN, AND pH IN SELECTED STREAMS IN OHIO \\ (OH042)}

Period of Project:

Continuous (reestablished

October 1985)

Project Leader:

Max S. Katzenbach

\section{Cooperators:}

Miami Conservancy District

U.S. Army Corp of Engineers

Ross County Engineers

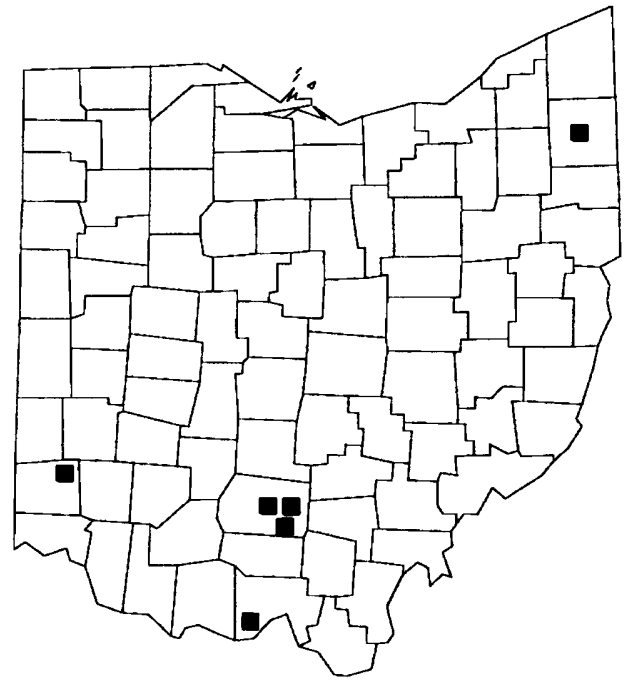

Purpose: (1) Continuously collect stream-temperature, dissolved-oxygen, specific-conductance, and $\mathrm{pH}$ data, which will serve as either direct or surrogate indicators of water-quality conditions in analyses conducted by the U.S. Geological Survey and State agencies to determine the effect of human activity on surface waters, and (2) provide relevant standardized data collected continuously for comprehensive study by the U.S. Geological Survey and other agencies for planning purposes and pollution control.

\section{Progress and significant}

results: Data collection and processing continued at all five water-quality monitor stations. Five stations have been added to the real-time data network. Modifications to the network, such as additions or deletions of stations, were made in response to program's needs. Data for 1992 were published in the annual hydrologic data report. 


\section{EFFECTS OF HIGHWAY DEICING CHEMICALS ON SHALLOW UNCONSOLIDATED AQUIFERS IN OHIO \\ (OH092)}

Period of Project:

January 1988 through

December 1997

\section{Project Leader:}

Allison L. Jones

\section{Cooperator:}

Ohio Department of Transportation

Purpose: (1) Determine the effects of highway-deicing chemicals, predominantly chloride, on the ground-water quality of shallow unconfined aquifers that underlie highways in Ohio, (2) determine those effects in different soil-type and climate areas of Ohio, (3) track the movement of chlorides away from the highway to observe seasonal variations in chloride migration, (4) determine yearly changes in chloride concentrations caused by variation in snowfall, and (5) determine the concentrations of selected ions in the soil and unsaturated zone. In Ohio, there is a lack of detailed knowledge concerning the movement of deicing salts after they have been applied to roads. The use of road salts has been increasing continuously since about 1940 . There is growing indication that all applied salts do not leave the area of application, but that some, in fact, accumulate. The Ohio Department of Transportation (ODOT) needs long-term data on the effects of salts on soil and ground water in Ohio.

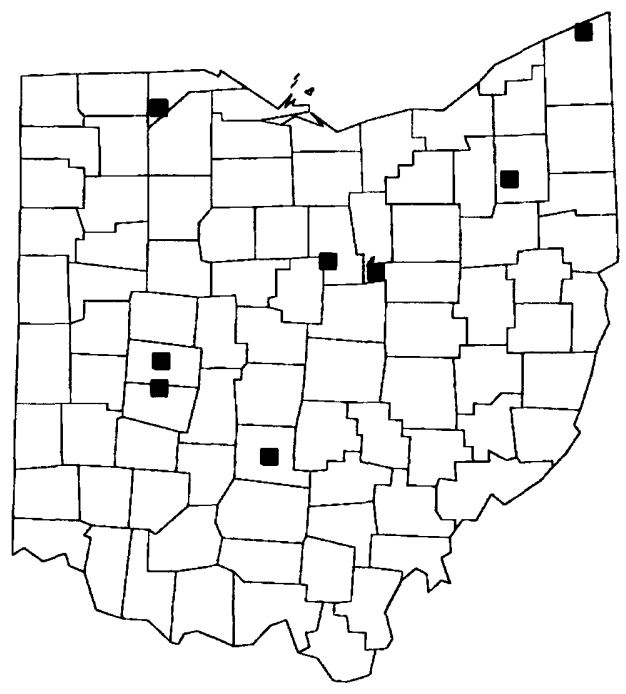

Progress and significant results: Eight sites were selected from a group of 55 potential sites through the use of maps of geology, glacial features, snowfall, and soil types. Records of county salt-application rates, waterwell logs, and other literature also were consulted. Each site was investigated by use of a ground-conductivity electromagnetic geophysical system. Test drilling was done at each potential site to determine formation type and content, water levels, and direction and velocity of ground-water flow. The eight study sites were selected in the following counties: Lucas, Pickaway, Champaign, Clark, Richland, Ashland, Portage, and Ashtabula. Seven to nine wells were drilled at each site and developed. Background water-quality samples were collected at all wells. Results of slug tests and a solute-transport model were used to predict ground-water velocity and determine placement of permanent wells. 


\section{EFFECTS OF HIGHWAY DEICING CHEMICALS ON SHALLOW UNCONSOLIDATED AQUIFERS IN OHIO \\ (OH092)_Continued}

Detailed programs for electronic data logging and storage devices were prepared. Instrumentation assembly and installation were completed. Detailed geophysical surveys were done at each site.

Ground-water samples are collected every 4 to 6 weeks at each site by use of a multilevel dialysis membrane groundwater sampler. Other information collected on an hourly basis includes: air temperature, ground temperature, specific conductance, water temperature, rainfall, and water level. A solutetransport model is being tested at the Lucas County site where the geology is fairly homogeneous. An interim report is planned for publication in 1994. 


\section{HYDROGEOLOGY AND GROUND-WATER QUALITY OF WRIGHT- PATTERSON AIR FORCE BASE, SOUTHWESTERN OHIO}

\section{(OH093)}

\section{Period of Project}

June 1987 through February 1993

\section{Project Leader:}

Denise H. Dumouchelle

\section{Cooperator:}

U.S. Air Force,

Air Force Logistics command,

645th Air Base Wing,

Office of Environmental Management

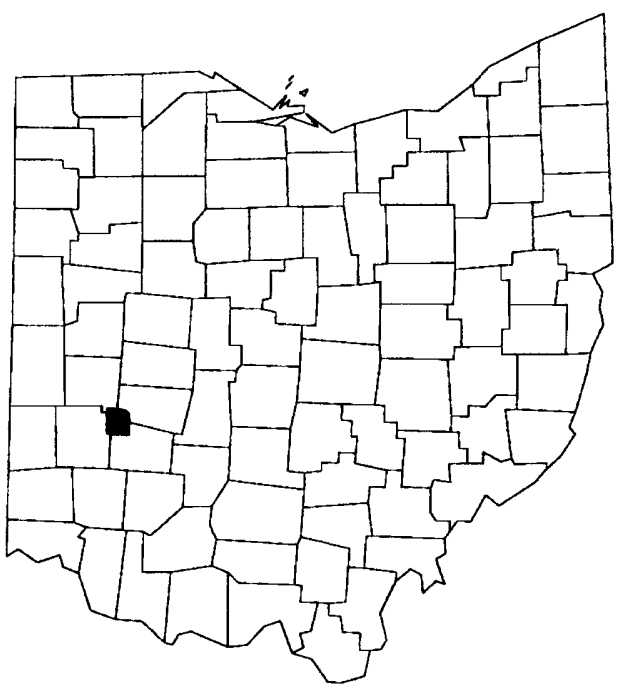

Purpose: The purpose of this project was to describe the hydrogeology, simulated flow, and quality of ground water at Wright-Patterson Air Force Base and the surrounding region.

\section{Progress and significant} results: Project is finished; results are published in the report, "Hydrogeology, simulated ground-water flow and ground-water quality, Wright-Patterson Air Force Base, Ohio," (U.S. Geological Survey Water-Resources Investigations Report 93-4047). Three other reports have also been published: "Lithologic, natural-gamma, grain-size and wellconstruction data for Wright-Patterson Air Force Base, Ohio" (U.S. Geological Survey Open-File Report-91-181); "Ground-water levels and flow in the vicinity of Wright-Patterson Air Force Base, Ohio, October- December 1987" (U.S. Geological Survey Water-

Resources Investigations Report 92- 4022); and "Altitude of top of bedrock in the vicinity of Wright-Patterson
Air Force Base, Ohio" (U.S. Geological Survey, Water Resources Investigat 92-4072).

The model simulates steady-state conditions based on water levels and hydraulic gradients measured from October to December 1987, and river discharges measured in 1991.

Ground water enters the modeled area primarily by river leakage ( 52 percent), boundary flux ( 29 percent), and precipitation (19 percent) and exits the modeled area primarily by boundary flux (45 percent), production wells (35 percent), and river leakage (20 percent). An analysis of the model output indicates that the contribution of water to the buried-valley glacial aquifer from the bedrock that forms the valley walls is about 2 to 4 percent of the total groundwater flow in the modeled area.

Shallow ground water of the glacial aquifer is characterized by elevated 


\section{HYDROGEOLOGY AND GROUND-WATER QUALITY OF WRIGHT- PATTERSON AIR FORCE BASE, SOUTHWESTERN OHIO (OH093)-Continued}

concentrations of sodium, chloride, sulfate, and nitrate that are related to human activities that alter the composition of precipitation-derived recharge and shallow ground water. All shallow ground-water samples contained detectable concentrations of tritium, indicating that recharge to these parts of the aquifer had occurred in the last few decades. Deeper parts of the glacial aquifer had significantly lower median concentrations of sodium and chloride indicating suggesting that recharge to these parts of the aquifer occurs slowly. Ground water collected from the deepest parts of the glacial aquifer (>180 ft.) did not contain measurable tritium concentrations, indicating that water in these zones entered the aquifer before 1953 . Stable isotope data for deuterium and ${ }^{18} \mathrm{O}$ indicate a meteoric origin for all ground water beneath WPAFB, but were inconclusive with respect to identifying distinct isotopic differences between ground water collected from the glacial drift or bedrock aquifers. Tritium concentrations, which were used to distinguish waters having a pre- and post1953 recharge component, indicate that most water entered the glacial aquifer after 1953. This finding indicates that recharge from shallow to deep parts of the aquifer occurs over time intervals of a few years or decades. However, some deep parts of the glacial aquifer did not contain measurable tritium, indicating that ground-water flow from recharge zones to these parts of the aquifer takes decades (or longer). Ground water collected from wells screened in the Brassfield Formation did contain tritium, indicating that recharge to the Brassfield strata occurred on a time scale of a few years to a few decades. However, ground water collected from wells completed in Richmondian strata did not contain tritium, indicating very slow recharge rates, an observation consistent with the inferred low permeability of the shale bedrock. 


\section{LAKE ERIE TRIBUTARY LOADING-OHIO, INDIANA, AND MICHIGAN (OH096)}

\section{Period of Project:}

Continuous since August 1987

\section{Project leader:}

John W. Roberts

\section{Cooperator:}

Ohio Department of Natural

Resources

Purpose: Determine phosphorus, sediment, and selected chemical loads in several major streams tributary to Lake Erie. Agriculture is the primary land use in the Ohio part of the Lake Erie basin and is considered responsible for much of the water-quality degradation of Lake Erie and its tributaries. In June 1983, the United States and Canada agreed to reduce phosphorus loading to Lake Erie by an additional 2,000 metric tons per year. A network of data-collection stations is needed on Lake Erie tributaries to determine (1) if this goal is being met, (2) the amounts of other chemicals entering the lake, and (3) other effects of agricultural land use.

\section{Progress and significant}

results: A network of data-collection stations has been established in Ohio on the Huron, Maumee, Sandusky, Cuyahoga, and Grand Rivers and Honey Creek. Suspended-sediment and waterquality samples and continuous data have been collected at all five sites.

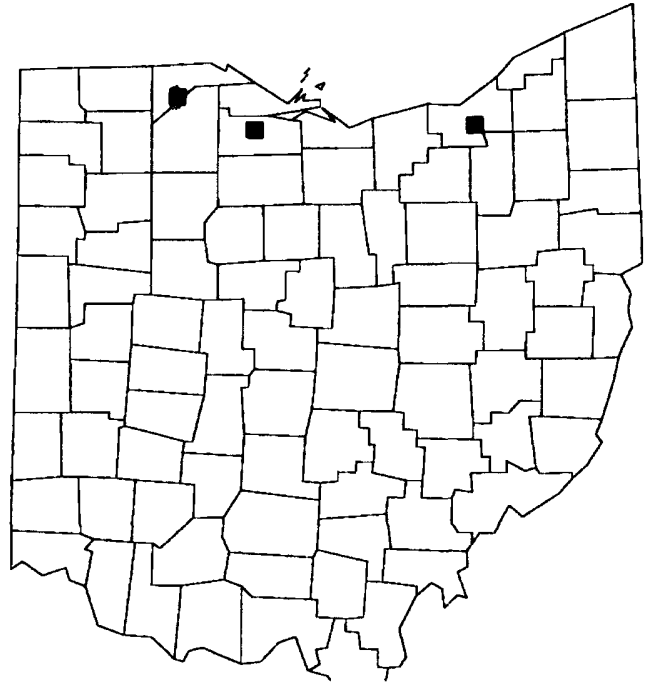

Sampling was discontinued at the end of the 1989 water year on Honey Creek and at the end of the 1991 water year for Grand and Huron Rivers. Annual loads have been computed for suspended sediment, total phosphorus, total Kjeldahlnitrogen, total and dissolved nitrite plus nitrate, and dissolved chloride. 


\section{EVALUATION OF BRIDGE-SCOUR DATA AT SELECTED SITES IN OHIO \\ (OH099)}

\section{Period of Project}

January 1989 through October 1996

\section{Project Leader:}

K. Scott Jackson

\section{Cooperator:}

Ohio Department of Transportation

Purpose: (1) Collect reliable and sufficient data during flood events to determine whether local scour, contraction scour, and general channel scour are taking place at 20 selected sites in Ohio, (2) compare and evaluate published local scour-prediction equations with observed data, and (3) compare local scour data collected by means of geophysical techniques with local scour data defined by physical measurements. Adequate definition of the potential scour (erosion of bed materials) at bridge sites is essential to proper design, construction, and maintenance of hydraulic structures in Ohio. Data will be collected during a 5-year period. And if hydrologic conditions permit, 50 total measurements will be obtained with at least 2 measurements made at each site.

\section{Progress and significant}

results: Currently 34 high-flow scour measurements have been obtained during the first 3 years of data collection at various bridge-scour measure- ment

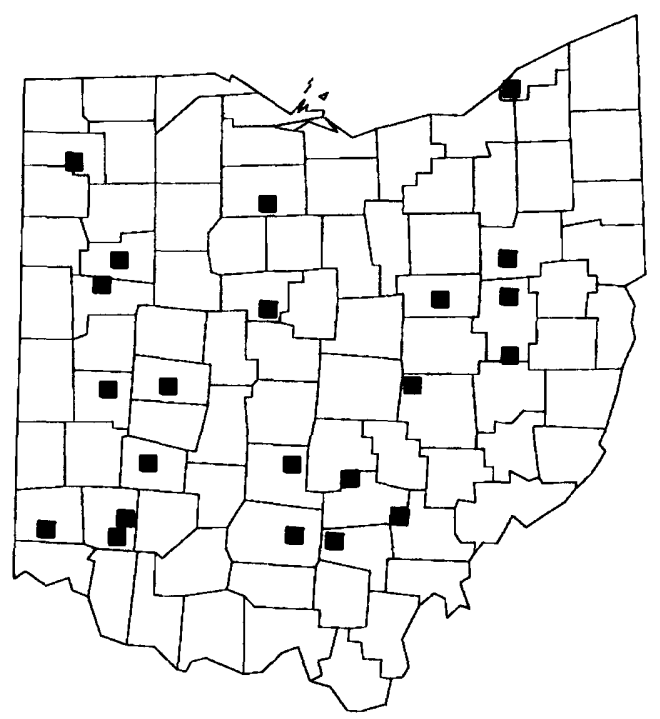

sites throughout the State. Modification to the scour-site network, such as additions or deletions of sites, have been made to respond to cooperator program needs. Limited use of fathometers (depth finders) has initially proved to be successful in the collection of scour data. Instantaneous discharge measurement data for 1992 were published in the annual hydrologic data report. 


\section{THE REGIONAL HYDROGEOLOGY OF THE BURIED TEAYS RIVER VALLEY SYSTEM \\ (OH100)}

Period of Project:

May 1989 to September 1993

Project Leader:

Rodney A. Sheets

\section{Cooperator:}

Midwestern Basin and Arches

Regional Aquifer Systems

Analysis

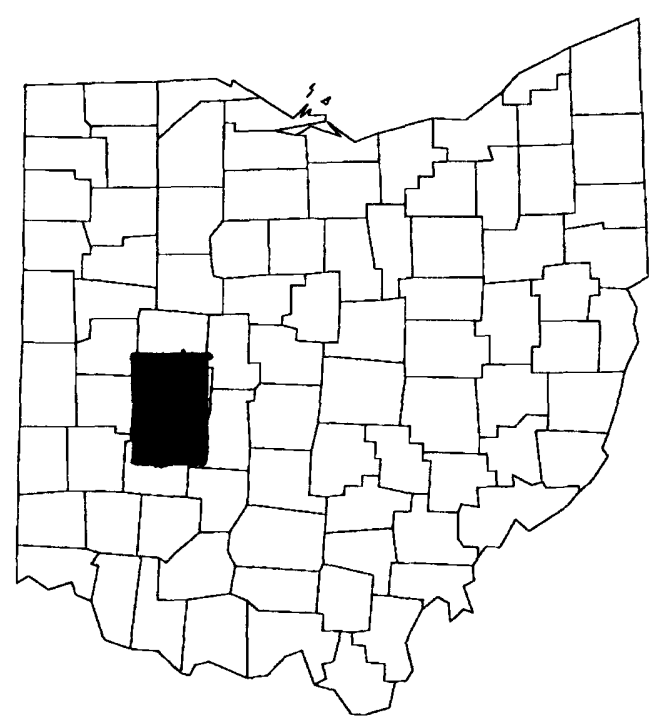

Purpose: To investigate the role of a major buried-valley system on the ground-water flow and chemistry of the carbonate and glacial aquifers of western Ohio and Indiana.

Progress and significant results: Ground-water and surface-water flow and chemistry have been examined at one site in southwestern Ohio near the boundary of the regional carbonate aquifer system. Major buried valleys that dissect the boundary between the Silurian carbonates and Ordovician shales act as ground-water drains to those sections of the regional ground-water-flow system. At a second site in northwestern Indiana, ground-water-flow and chemical data have been collected. The buried glacialdrift valleys in this area may act as local recharge areas, where not associated with major rivers. Where glacialdrift-filled valleys are overlain by rivers and dissect the eastern boundary of the carbonates, they also act as drains to the regional ground-water flow. 


\section{CALIBRATION OF A DYNAMIC STREAMFLOW MODEL FOR SUMMIT COUNTY, OHIO}

\section{(OH101)}

\section{Period of Project:}

August 1989 through July 1999

Project Leader:

James M. Sherwood

\section{Cooperator:}

Summit County Engineer

Purpose: Provide Summit County engineers with a means of accurately testing the effects of proposed development and runoff-controlling mechanisms on the flood characteristics of two drainage basins and numerous subbasins in west-central Summit County. The analytical tool to be developed will be based on onsite streamflow and rainfall data and will provide detailed information on peak discharge frequency, flood profiles, flood hydrographs, flood volumes, and flow velocities. The HSPF (Hydrologic Simulated ProgramFortran) model will be calibrated for each of the two basins. Data from 10 stream gages and 10 rain gages will be used to calibrate the models.

\section{Progress and significant}

results: All 10 rain gages and 9 of the 10 of the ten stream gages have been installed. Stage-discharge relations have been established for all nine streamgage sites. One year of data has been collected at all 9 stream gages and all 10

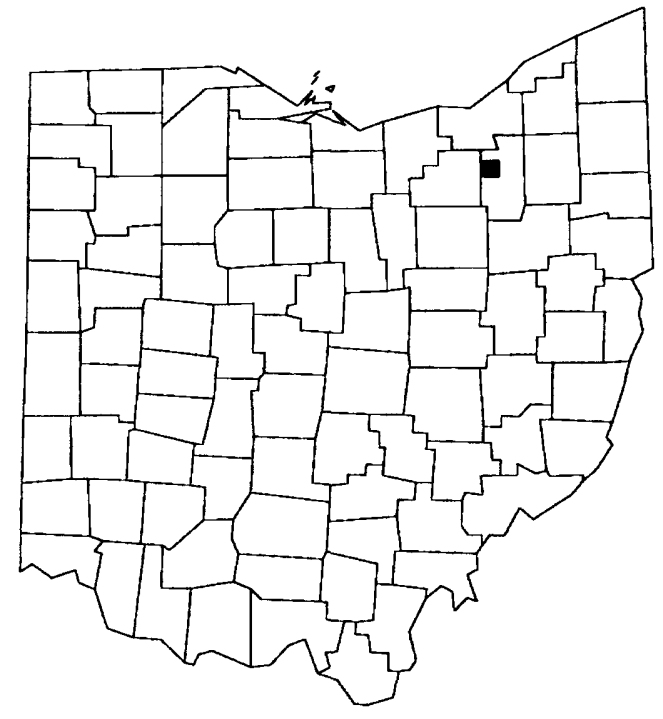

rain gages. Rainfall-runoff modeling will begin in 1994 . 


\section{CAPTURE-ZONE ANALYSIS OF THE SOUTH WELL FIELD, COLUMBUS, OHIO, BY USE OF A TRANSIENT GROUND-WATER-FLOW MODEL AND PARTICLE TRACKING (OH102)}

Period of Project:

November 1989 through January 1994

Project Leader:

Charles W. Schalk

\section{Cooperator:}

City of Columbus, Ohio

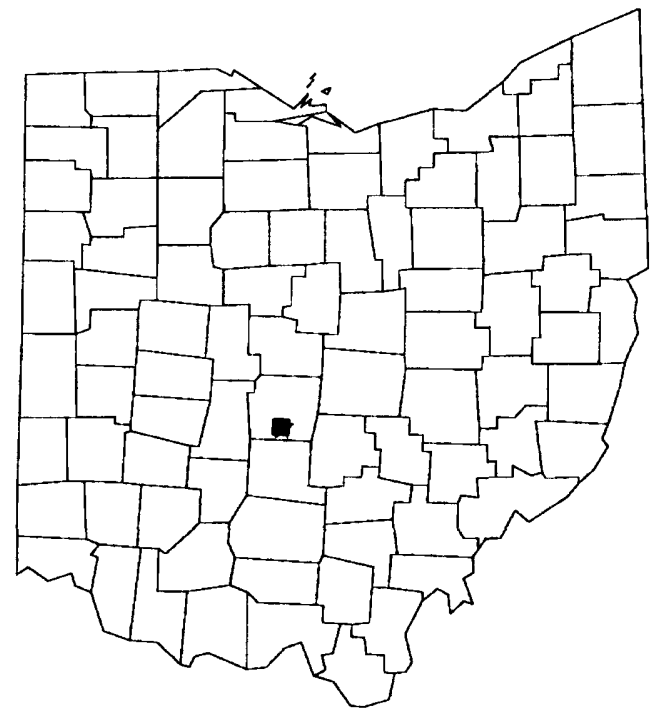

Purpose: (1) Present estimates of ground-water traveltimes and flow paths under transient flow to determine the zones of contribution to the City of Columbus' South Well Field, (2) monitor water levels quarterly at selected wells in the vicinity of the South Well Field, and (3) monitor water quality semiannually at two surface-water and five ground-water sites in the vicinity of the South Well Field.

\section{Progress and significant}

results: The report of the transient ground-water flow-model is in review. Transient particle tracking is a relatively new technology; a transient particle-tracking algorithm is being tested with data sets from this project. The program will be used to evaluate zones of contribution to wells at the South Well Field. Data collected in 1991-92 were published in respective annual hydrologic reports. 


\section{GROUND-WATER FLOW AND GEOCHEMISTRY BENEATH ABANDONED SURFACE-MINED WATERSHEDS RECLAIMED WITH FLUE-GAS DESULFURIZATION BYPRODUCTS AS SPOIL AND SOIL AMENDMENTS, SOUTHEASTERN OHIO}

Period of Project:

\section{(OH103)}

Through 1994

Project Leader:

Ralph J. Haefner

Cooperator:

The Ohio State University

Research Foundation

Purpose: (1) Determine short-term changes and develop the capability to detect long-term changes in groundwater quality beneath an abandoned surface coal-mine site reclaimed with flue-gas desulfurization (FGD) byproduct, and (2) describe the occurrence and mobility in ground water of elements derived from the FGD byproduct.

\section{Progress and significant results:} An extensive literature search has been done and resulted in the compilation of over 300 references regarding hydrology, geology, coal, and FGD technology. Work has centered on finding a suitable site for abandoned mine reclamation. Sociopolitical concerns regarding land application of FGD materials have caused delays in the site-selection process because landowners are cautious about possible environmental effects.

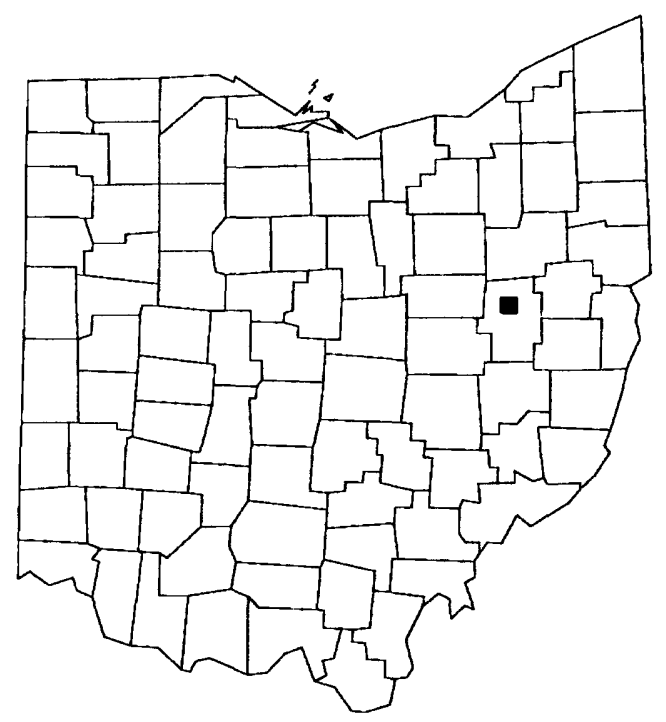




\section{DAYTON REGIONAL GROUND-WATER-FLOW MODEL (OH104-01)}

Period of Project:

June 1991 through September 1996

Project leader:

Denise H. Dumouchelle

\section{Cooperator:}

U.S. Environmental Protection Agency-Region V

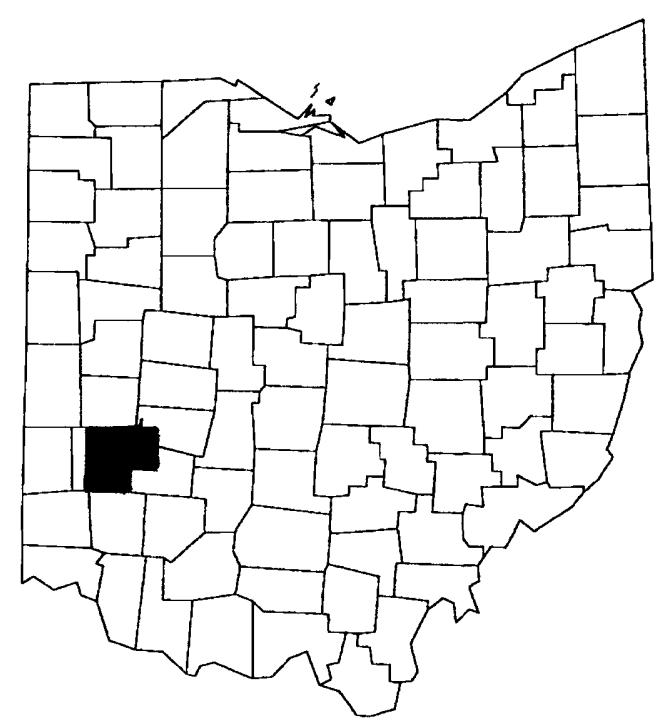

Purpose: To improve the understanding of the regional ground-waterflow system of the buried-valley aquifer system by use of a numerical groundwater-flow model.

\section{Progress and significant}

results: The initial phase of the project, the compilation of existing regional and site-specific data, has begun. Draft maps, in digital format, of the surficial geology, waste-site locations, and bedrock topography are complete. These maps are based on publications or data collected from U.S. Environmental Protection Agency or Ohio Department of Natural Resources files. 


\section{Industrial Excess Landfill \\ (OH104-02)}

\section{Period of Project:}

Continuous from 1992

\section{Project leader:}

Denise H. Dumouchelle

\section{Cooperator:}

U.S. Environmental Protection Agency-Region V

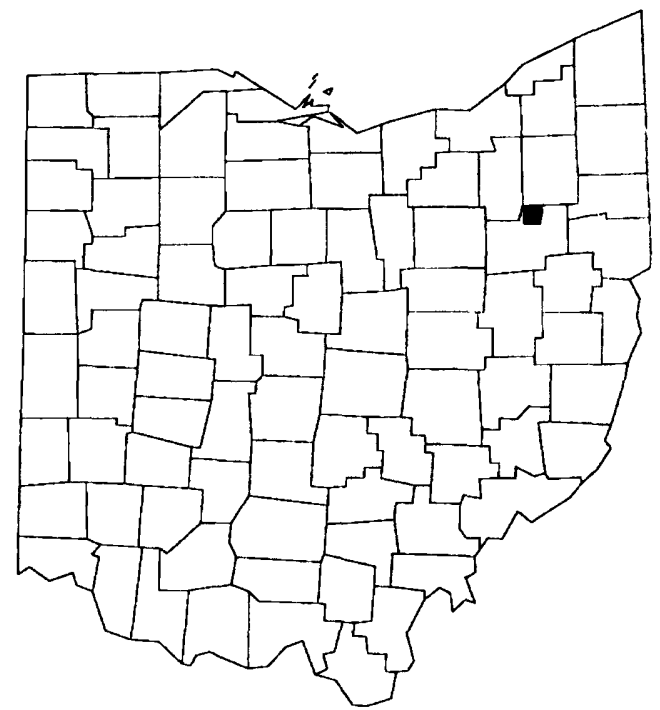

Purpose: To assist U.S. Environmental Protection Agency as needed in the collection and interpretation of hydrogeologic data at the Industrial Excess Landfill (IEL) site in Uniontown, Ohio.

Progress and significant findings: In the summer of 1992, the USGS drilled a well at the IEL site to collect additional water-quality data. In the spring of 1993, USEPA requested that the USGS review new data on water levels and ground-water flow from the site. In particular, to compare the recent data with the 1989 report "Ground-water levels and flow near the Industrial Excess Landfill, Uniontown, Ohio" (U.S. Geological Survey Open-File Report 89-272). 


\section{EVALUATION OF THE EFFECTS OF PHYSICAL, CHEMICAL, AND BIO- LOGICAL FACTORS ON PESTICIDE SORPTION, BIOTRANSFORMA- TION, AND TRANSPORT IN A BURIED-VALLEY AQUIFER (OH105)}

Period of Project:

March 1990 through September 1993

\section{Project Leader:}

Martha Jagucki

\section{Cooperators:}

The Toxic Substances Hydrology

Program

Purpose: (1) Characterize spatial variations in the physical properties of the aquifer beneath the Management Systems Evaluation Area (MSEA), (2) characterize spatial and temporal variations in the aqueous chemistry of the aquifer, (3) develop a conceptual flow model and water budget for the aquifer beneath the MSEA, (4) determine whether a correlation exists between aquifer physical properties of the aquifer and the sorptive capacity of aquifer sediments, (5) characterize spatial variations in microbial numbers and diversity in the aquifer, (6) determine whether a correlation exists between microbial numbers and physical aquifer properties and (or) aqueous constituent concentrations,

(7) determine whether the geomicrobial population in the aquifer can degrade atrazine, and (8) determine whether atrazine in ground water causes toxic inhibition of denitrification.

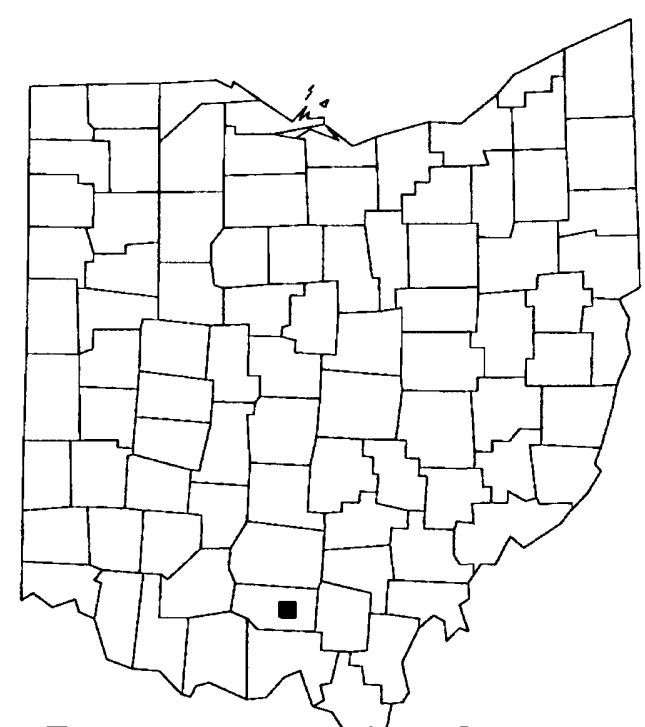

Progress and significant results: Numerous subsurface sediment samples were collected during the installation of 37 wells. Analyses of the samples for grain-size distribution, mineralogy, and organic carbon content have been completed. Water samples collected from 32 ground-water locations and 2 surface-water locations three times during 1991, were analyzed for field parameters, major ions, selected trace metals, nutrients, and triazine herbicides. From August 1991 to July 1993,15 wells were instrumented with continuous specific-conductance and temperature recorders to collect data

Twenty-four sediment samples collected during well installation were analyzed for microbial numbers and diversity. Microbial numbers varied between $<10^{3}$ colonies and $143 \times 10^{3}$ colonies per gram of dry sediment. Although no correlation existed between microbial numbers and depth below ground surface, some samples showed a marked differ- 
ence in colony color and morphology

EVALUATION OF THE EFFECTS OF PHYSICAL, CHEMICAL, AND BIOLOGICAL FACTORS ON PESTICIDE SORPTION, BIOTRANSFORMATION, AND TRANSPORT IN A BURIED-VALLEY AQUIFER

\section{(OH105)_Continued}

with depth. Only a slight correlation was found between microbial numbers and percent silt and clay in the sediment samples.

In laboratory experiments covering a 23-day incubation period, native subsurface microbes were able to mineralize $<0.1$ percent of the ring-labeled atrazine and $<0.1$ to 1.5 percent of the chainlabeled atrazine added to aquifer sediment samples. This indicates that the atrazine ring structure is resistant to degradation in ground water. The measured rate of atrazine chain degradation was slow but still may be significant in field studies, given the typically long residence time of ground water.

In laboratory experiments where microcosms of native subsurface sediments, no evidence of inhibition of denitrification by atrazine was found at atrazine concentrations as high as $500 \mu \mathrm{g} /$.

Apparently the correlation between the presence of atrazine and nitrates in ground water is not due to toxic inhibition of denitrification by atrazine.

Raw data from sediment, microbial numbers, and water-quality analyses and continuous water-level and specificconductance records have been published in Water Resources Data-Ohio, Volume 2 for water years 1991 and 1992. "Atrazine Mineralization Potential of Alluvial-Aquifer Sediments under Aerobic Conditions" was published in Environmental Science and Technology, 1992 , volume 26 , p. 1556-1559. Two additional interpretive reports are being written: "Hydrogeology and Water Quality at the Management Systems Evaluation Area near Piketon, Ohio," and "Toxic Inhibition of Denitrification by Atrazine." 


\section{DISCHARGE CHARACTERISTICS OF SELECTED LONGITUDINAL DRAIN MATERIALS \\ (OH106)}

Period of Project:

August 1990 to October 1994

Project Leader:

David E. Straub

\section{Cooperator:}

Ohio Department of Transportation

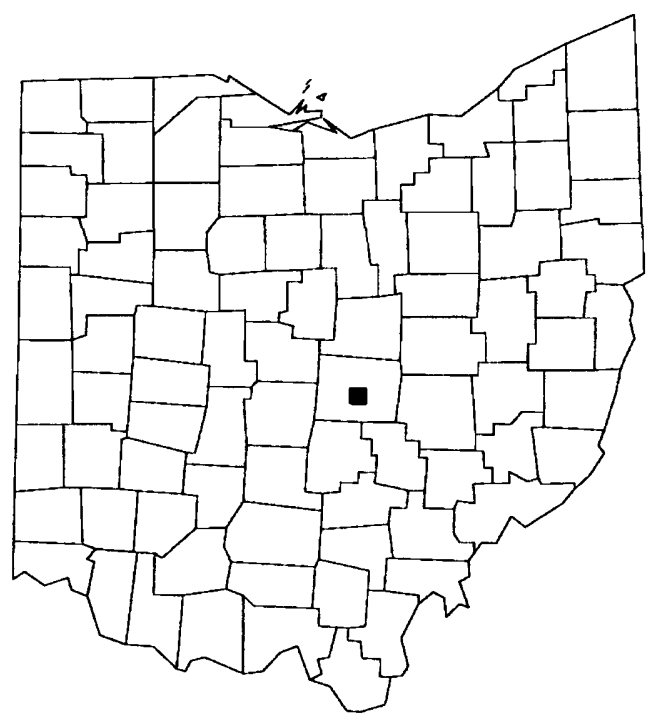

Purpose: The purpose of this study is to document the relative performance of four longitudinal drain-material products under nearly equal geological and environmental field settings. Damp highway subbases are known to hasten pavement deterioration. As a consequence, current recommended design standards generally include permeable base courses with longitudinal drains underlying the shoulder to mainline joints.

\section{Progress and Significant}

Results: Data collection continued at all four sites on State Route 16, just east of Granville, Ohio. Rainfall and discharge from the four edge-drain materials were measured for the past two datacollection periods from April to December. Lag times between the centroid of the rainfall and discharge hydrographs were computed for selected events throughout both periods of time. 


\section{HYDROLOGIC AND BIOLOGIC FACTORS AFFECTING FECAL- INDICATOR BACTERIA DISCHARGE AND IMPLICATIONS FOR WATER-CONTACT RECREATION IN THE CUYAHOGA RIVER, SUMMIT AND CUYAHOGA COUNTIES, OHIO \\ (OH107)}

Period of Project:

April 1991 through September 1994

Project Leader:

Donna N. Myers

\section{Cooperators:}

Ohio Water Development Authority

County of Summit

City of Akron

Northeast Ohio Regional Sewer

District

Cuyahoga River Community

Planning Organization

Purpose: Water-contact recreation in many Ohio rivers must be restricted after rainfall and runoff to protect the public from potentially unhealthful water-quality conditions associated with the occurrence of pathogenic microorganisms and the fecal-coliform bacteria that indicate their presence.

The objectives of this project are to quantify processes including transport, die-off, deposition and resuspension of Escherichia coli (E. coli) and fecalcoliform bacteria in a segment of the Cuyahoga River. Measurements of these processes will be applied in model simulations of the river to predict when levels of $E$. coli and fecal-coliform bacteria will exceed established safe levels during wet-weather periods.

\section{Progress and significant}

results: Four bacterial die-off studies and two time-of-travel and fecalindicator bacteria transport studies

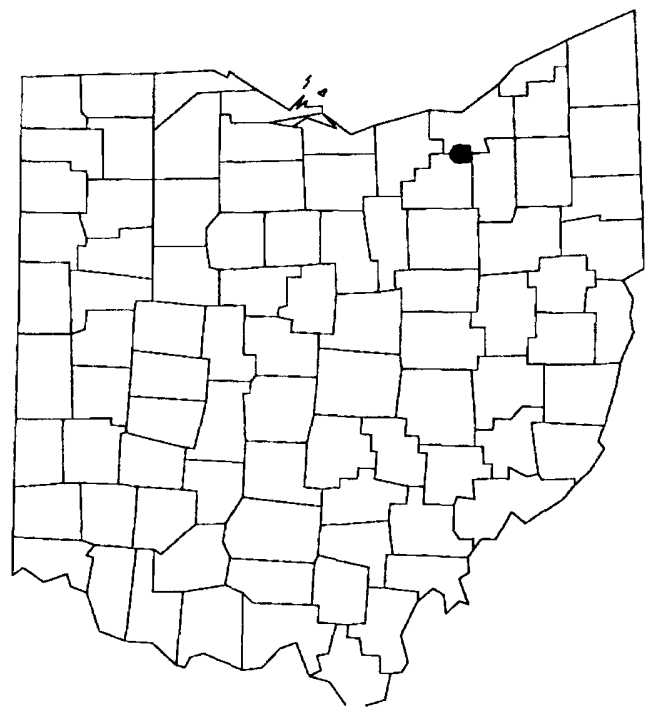

have been completed. Field studies and model calibration and verification are being completed in 1993. An initial report comparing $E$. coli to fecal-coliform bacteria as predictors of recreational water quality was completed. 


\section{ZONES OF CONTRIBUTION TO WATER SUPPLY WELLS AT WRIGHT- PATTERSON AIR FORCE BASE, OHIO (OH108)}

Period of Project:

October 91 to September 1994

Project Leader:

Rodney A. Sheets

\section{Cooperator:}

Wright-Patterson Air Force Base, Office of Environmental Management

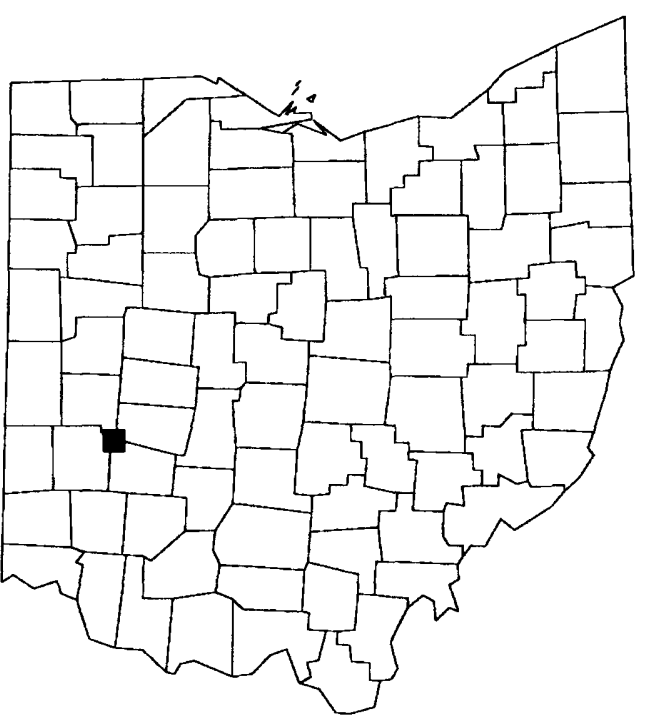

Purpose: (1) To delineate, using a numerical ground-water-flow model, zones of contribution to well fields at Wright-Patterson Air Force Base, and (2) to geographically reference potential contamination sources to the watersupply wells. The zones of contribution and source data will be used by Base officials to aid in the design of a wellhead-protection strategy that conforms to the Ohio Environmental Protection Agency's wellhead protection program.

\section{Progress and Significant}

Results: A regional ground-water-flow model of the Base area has been used to identify contributing recharge areas to two active and one inactive watersupply well fields on the Base. Construction and pumping information for the wells has been compiled. Additional geophysical data have been collected in order to refine the regional model to a set of subregional models including the well fields. Roads, buildings, and other

geographic features have been entered into a geographic information system to facilitate comparison with zones of contribution. 


\section{WRIGHT-PATTERSON AIR FORCE BASE BASEWIDE MONITORING PROGRAM}

\section{(OH109)}

\section{Period of Project:}

October 1991 through 1996

\section{Project Leader:}

William L. Cunningham

\section{Cooperator:}

U.S. Air Force,

645th Air Base Wing,

Office of Environmental

Management

Purpose: The purpose of the Base Wide Monitor Program is to assess the impacts of contamination sources at Wright-Patterson Air Force Base (WPAFB) on regional ground water and surface water by monitoring water quality at the Base. This is a multi-year, flexible program to identify trends in regional water quality. The investigative approach of the program is designed to implement a long-term Basewide ground-water and surface-water sampling network to:

(a) characterize current groundwater and surface-water quality,

(b) describe water-quality changes as water enters, flows through, and exits base boundaries,

(c) conduct statistical analyses of water quality, and

(d) estimate the effect of WPAFB on regional water quality.

A synthesis of the statistical, hydraulic, and geochemical investigations will provide a more complete characterization of the ground

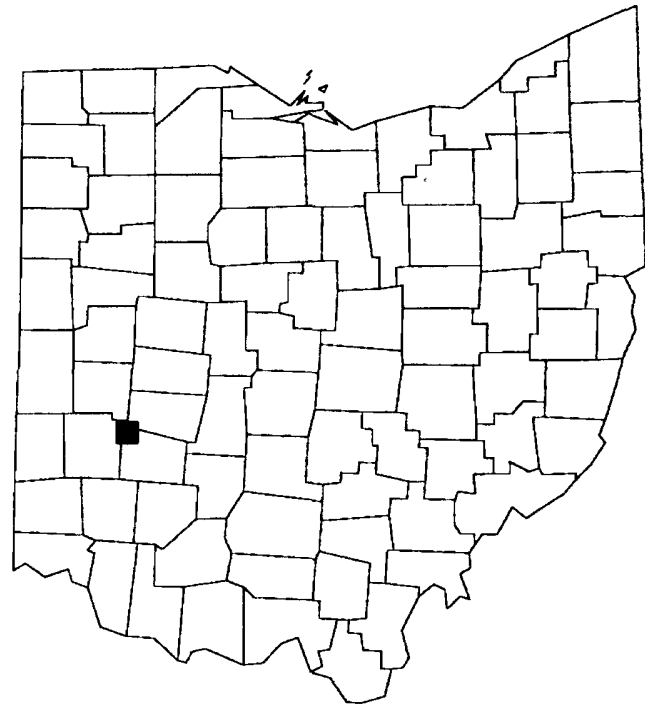

water as it enters, traverses, and exits WPAFB. Upgradient, interior, and downgradient water-quality data along ground-water-flow paths will result in a more complete understanding of the fate and transport of chemical constituents at WPAFB. The resultant information will be useful in planning for the design of future remediation strategies on the Base.

\section{Progress and significant} results: An INGRES data base has been designed to store and manipulate the large amount of data to be generated by the program. A project workplan was developed which describes in detail the plan of study, including specific field methods to be used. Twenty-nine surface-water sites have been located. A ground-water-monitoring network consisting of 79 existing and 51 planned wells has been designed. The drilling program began in March 1993. Groundand surface-water sampling will begin in July 1993. 
Period of Project:

October 1992 through

September 1995

Project Leader:

Kevin D. Metzker

\section{Cooperator:}

Franklin and Madison Counties City of Columbus

Purpose: Investigate the relations of the macroinvertebrate and algal communities to hydrology, water chemistry, and physical disturbance associated with runoff events. Floods are known to cause significant and sometimes frequent disruptions of aquatic community by washing out macroinvertebrates and algae. Resilient macroinvertebrates and algae recolonize within days, weeks, or a month, depending on the extent of washout. Although the phenomena of washout and recolonization have been documented, the relation between washout and recolonization and the physical stream environment is not well understood.

\section{Progress and significant}

results: In 1992, 30 synoptic sites were sampled throughout the Big Darby Basin to identify three sites for continued data collection. Three gaging stations were constructed to monitor discharge, sediment, and water quality of Big Darby Creek and two major

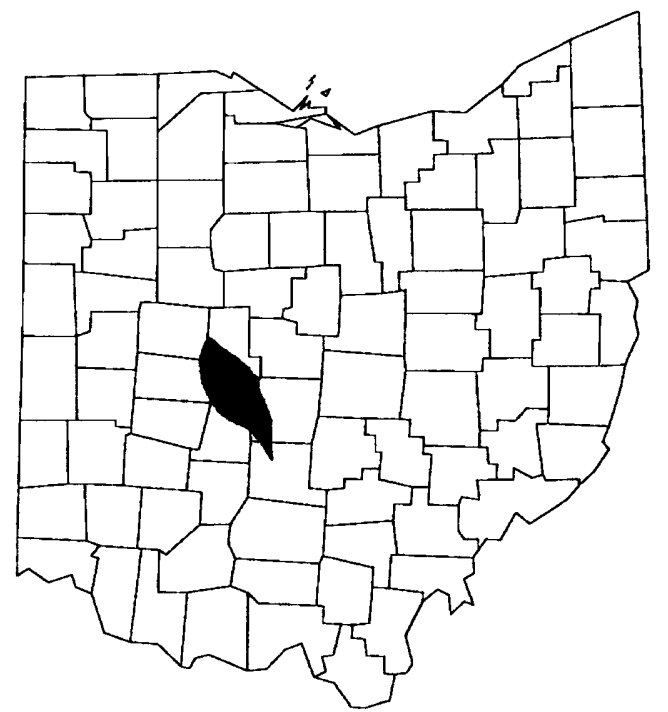

tributaries. Initial samplings of macroinvertibrates and algae were completed at all three sites. 


\section{USE OF CHLOROFLUOROCARBONS TO CALIBRATE A REGIONAL GROUND-WATER-FLOW MODEL OF A BURIED-VALLEY AQUIFER NEAR DAYTON, OHIO \\ (OH-112)}

Period of Project:

April 1992 through September 1996

\section{Project Leader:}

Gary L. Rowe

\section{Cooperator:}

Miami Conservancy District

Purpose: To develop a threedimensional ground-water-flow model and associated hydrogeologic data base of the Great Miami buried-valley aquifer in the vicinity of Dayton, Ohio. To assist in calibration of the ground-water-flow model, an environmental tracer study based on the newly developed chlorofluorocarbon and tritium ${ }^{3} \mathrm{He}$ age-dating techniques of the aquifer will also be done. Results of age-dating studies along regional flow paths will be compared with particle-tracking simulations done with the calibrated flow-model.

\section{Progress and significant}

results: Organization and project planning activities are underway. Datacollection activities for fiscal year 1993 will consist of collection of basic hydrogeologic data needed for calibration of the ground-water-flow model, including: 1) synoptic water-level data, 2) a gainloss study of major streams and rivers of the study area, 3) measurement of stream profiles and channel

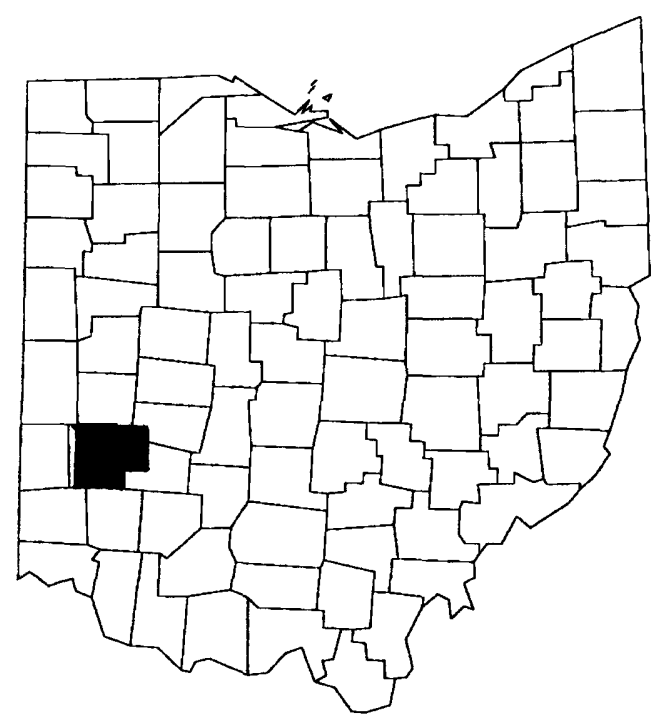

cross-sections, and 4) measurements of streambed conductance. Approximately 30 to 40 water-quality samples will be collected from wells throughout the buried-valley aquifer for analysis of chlorofluorocarbons compounds and tritium $-{ }^{3} \mathrm{He}$ to assess the viability of these age-dating techniques in the study area. 


\section{SURFACE-WATER STATIONS FOR WHICH RECORDS ARE PUBLISHED}

This section contains a list of hydrologic data stations for which daily records have been published by the U.S. Geological Survey in 1993-94. Surface-water stations are numbered and listed in downstream order along the main stem. A station on a tributary entering between two main-stem stations is listed between them. A similar order is followed in listing stations on first rank, second rank, and other ranks of tributaries. This downstream-order numbering system is a permanent system of numerical designations adopted by the Survey in 1950.

Surface-water stations for which daily data are collected are classified as: discharge, stage only, sediment, continuous-record water quality, and reservoir or lake contents and (or) elevation. Daily discharge and stage-only stations are sites instrumented to provide a continuous stage record. For daily discharge stations, calculations of mean daily discharge, peak flows during floods, and total monthly and yearly runoff are made by applying stage data to a stage-discharge rating curve derived from actual discharge measurements.

Pool-elevation data collected at reservoir or lake stations are used to determine periodic changes in the amount of water held in storage. Continuous-record waterquality stations are sites equipped to record one or more physical or chemical characteristics. The record is used to determine maximum and minimum daily values. For daily sediment stations, samples collected daily are analyzed for their suspendedsediment concentrations to develope a curve from which daily mean concentrations are determined. Suspended-sediment discharges are computed by multiplying water discharge times sediment concentration times a conversion factor.

In addition to the daily stations listed, data are collected at many sites where daily stations are not feasible. At these partial-record stations, data are collected at regular intervals ranging from one to several times annually. Types of data collected include peak discharge, low-flow discharge, chemical quality, sediment, and biologic. Information about locations of partial-record stations and types of data collected is available upon request. 
Standard abbreviations used in station names:

$\begin{array}{llllll}\text { ab } & \text { above } & \text { E } & \text { east } & \mathrm{nr} & \text { near } \\ \text { B } & \text { branch } & \text { F } & \text { fork } & \mathrm{R} & \text { river } \\ \text { bk } & \text { brook } & \text { G } & \text { great } & \text { re } & \text { reservoir } \\ \text { bl } & \text { below } & \text { L } & \text { little } & \text { m } & \text { run } \\ \text { C } & \text { creek } & \text { lk } & \text { lake } & \text { s } & \text { south } \\ \text { ca } & \text { canal } & \text { M } & \text { middle } & \text { tr } & \text { tributary } \\ \text { d } & \text { ditch } & \text { n } & \text { north } & \text { W } & \text { west }\end{array}$

The letters after the station names designate type of data: (B) biological, (C) chemical, (D) discharge, (E) contents and (or) elevation, (M) water-quality monitor, (NASQAN) National stream-quality accounting network, (R) radiochemical, (S) sediment, (T) temperature, and (CSG) crest-stage gage

\begin{tabular}{|c|c|c|}
\hline $\begin{array}{c}\text { Station } \\
\text { number }\end{array}$ & \multicolumn{1}{c|}{ Station } & $\begin{array}{c}\text { Type of } \\
\text { data }\end{array}$ \\
\hline & OHIO RIVER BASIN & \\
\hline & Ohio River: & \\
\hline 03086500 & BEAVER RIVER BASIN & \\
\hline 03091500 & Mahoning R (head of Beaver R) at Alliance & $\mathrm{D}$ \\
\hline 03092000 & Kale C nr Pricetown & $\mathrm{D}$ \\
\hline 03092090 & W B Mahoning R nr Ravenna & $\mathrm{D}$ \\
\hline 03093000 & Eagle C at Phalanx & $\mathrm{D}$ \\
\hline 03094000 & Mahoning R at Leavittsburg & $\mathrm{D}$ \\
\hline
\end{tabular}




\section{SURFACE-WATER STATIONS-Continued}

\begin{tabular}{|c|c|c|}
\hline $\begin{array}{l}\text { Station } \\
\text { number }\end{array}$ & Station & $\begin{array}{c}\text { Type of } \\
\text { data }\end{array}$ \\
\hline 03097550 & Mahoning $R$ at Ohio Edison Power Plant at Niles & $\mathrm{D}$ \\
\hline \multirow[t]{2}{*}{03098600} & Mahoning $\mathrm{R}$ bl West Avenue Bridge at Youngstown & $\mathrm{DM}$ \\
\hline & Shenango R: & \\
\hline \multirow[t]{2}{*}{03102950} & Pymatuning $\mathrm{C}$ at Kinsman & $\mathrm{D}$ \\
\hline & LITTLE BEAVER CREEK BASIN & \\
\hline \multirow[t]{2}{*}{03109500} & L Beaver C nr East Liverpool & $\mathrm{D}$ \\
\hline & YELLOW CREEK BASIN & \\
\hline \multirow[t]{2}{*}{03110000} & Yellow C nr Hammondsville & $\mathrm{D}$ \\
\hline & SHORT CREEK BASIN & \\
\hline \multirow[t]{2}{*}{03111500} & Short C nr Dillonvale & $\mathrm{D}$ \\
\hline & WHEELING CREEK BASIN & \\
\hline \multirow[t]{2}{*}{03111548} & Wheeling C bl Blaine & DS \\
\hline & CAPTINA CREEK BASIN & \\
\hline \multirow[t]{3}{*}{03114000} & Captina $\mathrm{C}$ at Armstrongs Mills & $\mathrm{D}$ \\
\hline & MUSKINGUM RIVER BASIN & \\
\hline & Tuscarawas R (head of Muskingum R): & \\
\hline 03117000 & Tuscarawas $\mathrm{R}$ at Massillon & $\mathrm{D}$ \\
\hline 03117500 & Sandy $\mathrm{C}$ at Waynesburg & $\mathrm{D}$ \\
\hline 03118000 & $\begin{array}{l}\text { M B Nimishillen C (head of Nimishillen C) at } \\
\text { Canton }\end{array}$ & $\mathrm{D}$ \\
\hline 03118500 & Nimishillen $\mathrm{C}$ at North Industry & $\mathrm{D}$ \\
\hline 03120500 & McGuire C bl Leesville Dam, nr Leesville & CSG \\
\hline 03122500 & Tuscarawas R bl Dover Dam, nr Dover & CSG \\
\hline 03124000 & Sugar Creek bl Beach City Dam, nr Beach City & CSG \\
\hline
\end{tabular}


SURFACE-WATER STATIONS-Continued

\begin{tabular}{|c|c|c|}
\hline $\begin{array}{l}\text { Station } \\
\text { number }\end{array}$ & Station & $\begin{array}{c}\text { Type of } \\
\text { data }\end{array}$ \\
\hline \multirow[t]{2}{*}{03124500} & Sugar C at Strasburg & $\mathrm{D}$ \\
\hline & Stillwater C & \\
\hline 03126000 & Stillwater C at Piedmont & CSG \\
\hline 03127000 & Stillwater C at Tippecanoe & CSG \\
\hline \multirow[t]{2}{*}{03127500} & Stillwater C at Uhrichsville & CSG \\
\hline & Clear F (head of L Stillwater C): & \\
\hline 03128500 & L Stillwater C bl Tappan Dam, at Tappan & CGS \\
\hline 03129000 & Tuscarawas $R$ at Newcomerstown & $\mathrm{D}$ \\
\hline 03130000 & $\begin{array}{l}\text { Black F (head of Walhonding R) bl Charles Mill } \\
\text { Dam, nr Mifflin }\end{array}$ & CSG \\
\hline 03131500 & Black F at Loudonville & CSG \\
\hline \multirow[t]{3}{*}{03133500} & Clear F bl Pleasant Hill Dam nr Perrysville & CSG \\
\hline & Mohican R (continuation of Black F): & \\
\hline & Lake F: & \\
\hline 03135000 & L F bl Mohicanville Dam, nr Mohicanville & $\mathrm{D}$ \\
\hline 03136500 & Kokosing $\mathrm{R} n r$ Mount Vernon & $\mathrm{D}$ \\
\hline 03138500 & $\begin{array}{l}\text { Walhonding } \mathrm{R} \text { (continuation of Mohican } \mathrm{R} \text { ) bl } \\
\text { Mohawk Dam, at Nellie }\end{array}$ & CSG \\
\hline 03139000 & Killbuck C at Killbuck & $\mathrm{D}$ \\
\hline 03140000 & Mill C nr Coshocton & $\mathrm{D}$ \\
\hline \multirow[t]{3}{*}{03040500} & $\begin{array}{l}\text { Muskingum R (continuation of Tuscarawas R) } \mathbf{n r} \\
\text { Coshocton }\end{array}$ & $\mathrm{D}$ \\
\hline & Wills C: & \\
\hline & Seneca F: & \\
\hline 03141500 & Seneca F bl Seneca Dam, nr Senecaville & CSG \\
\hline 03142000 & Wills $\mathrm{C}$ at Cambridge & $\mathrm{D}$ \\
\hline
\end{tabular}




\section{SURFACE-WATER STATIONS-Continued}

\begin{tabular}{|c|c|c|}
\hline $\begin{array}{l}\text { Station } \\
\text { number }\end{array}$ & Station & $\begin{array}{c}\text { Type of } \\
\text { data }\end{array}$ \\
\hline 03143500 & Wills C bl Wills C Dam, at Wills Creek & CSG \\
\hline \multirow[t]{2}{*}{03144000} & Wakatomika C nr Frazeysburg & $\mathrm{D}$ \\
\hline & Licking R: & \\
\hline 03145000 & S F Licking R (head of Licking R) nr Hebron & $\mathrm{D}$ \\
\hline 03146500 & Licking $R$ nr Newark & $\mathrm{D}$ \\
\hline 03147500 & Licking $\mathrm{R}$ bl Dillon dam, nr Dillon Falls & CSG \\
\hline \multirow[t]{3}{*}{03150300} & Muskingum $\mathrm{R} n \mathrm{n}$ Beverly & $\mathrm{D}$ \\
\hline & HOCKING RIVER BASIN & \\
\hline & Hocking R: & \\
\hline 03157000 & Clear C nr Rockbridge & $\mathrm{D}$ \\
\hline 03157500 & Hocking River at Enterprise & D \\
\hline \multirow[t]{2}{*}{03159510} & Hocking River bl Athens (NASQAN) & DCS \\
\hline & SHADE RIVER BASIN & \\
\hline \multirow[t]{2}{*}{03159540} & Shade $\mathrm{R} n \mathrm{r}$ Chester & $\mathrm{D}$ \\
\hline & RACCON RIVER BASIN & \\
\hline \multirow[t]{2}{*}{03202000} & Racoon Cr at Adamsville & $\mathrm{D}$ \\
\hline & SCIOTO RIVER BASIN & \\
\hline 03219500 & Scioto R nr Prospect: & $\mathbf{D}$ \\
\hline 03219590 & Bokes C nr Warrensburg & $\mathbf{D}$ \\
\hline 03220000 & Mill C nr Bellepoint & $\mathrm{D}$ \\
\hline \multirow[t]{2}{*}{03221000} & Scioto R bl O' Shaughnessy Dam nr Dublin & $\mathrm{D}$ \\
\hline & Olentangy River: & \\
\hline 03223000 & Olentangy $R$ at Claridon & $\mathrm{D}$ \\
\hline 03225500 & Olentangy $R \mathrm{nr}$ Delaware & $\mathrm{D}$ \\
\hline
\end{tabular}




\section{SURFACE-WATER STATIONS—Continued}

\begin{tabular}{|c|c|c|}
\hline $\begin{array}{l}\text { Station } \\
\text { number }\end{array}$ & Station & $\begin{array}{c}\text { Type of } \\
\text { data }\end{array}$ \\
\hline 03227500 & Scioto $R$ at Columbus & $\mathrm{D}$ \\
\hline 03228300 & Big Walnut $\mathrm{C}$ at Sunbury & $\mathrm{D}$ \\
\hline 03228500 & Big Walnut $\mathrm{C}$ at Central College & $\mathrm{D}$ \\
\hline 03228805 & Alum $\mathrm{C}$ at Africa & $\mathrm{D}$ \\
\hline 03229000 & Alum $\mathrm{C}$ at Columbus & $\mathrm{D}$ \\
\hline 03229500 & Big Walnut $\mathrm{C}$ at Rees & DS \\
\hline 03230310 & L Darby Cr at West Jefferson & DS \\
\hline 03230450 & Hellbranch Run nr Harrisburg & DS \\
\hline 03230500 & Big Darby $\mathrm{C}$ at Darbyville & $\mathrm{D}$ \\
\hline 03230900 & Dear C nr Pancoastburg & $\mathrm{D}$ \\
\hline 03231000 & Dear C at Williamsport & CSG \\
\hline \multirow[t]{2}{*}{03231500} & Scioto $\mathrm{R}$ at Chillicothe & $\mathrm{DM}$ \\
\hline & Paint C: & \\
\hline \multirow[t]{2}{*}{03232470} & Paint $\mathrm{C}$ bl Paint $\mathrm{C}$ Dam nr Bainbridge & CSG \\
\hline & Rocky F: & \\
\hline 03232500 & Rocky F nr Barretts Mills & $\mathrm{D}$ \\
\hline 03234000 & Paint C nr Bourneville & $\mathrm{D}$ \\
\hline 03234300 & Paint $\mathrm{C}$ at Chillicothe & $\mathrm{DM}$ \\
\hline \multirow[t]{2}{*}{03234500} & Scioto R at Higby (NASQAN) & DCBMTS \\
\hline & Reservoirs in Scioto R Basin & $\mathrm{E}$ \\
\hline & UPPER TWIN CREEK BASIN & \\
\hline \multirow[t]{2}{*}{03237280} & Upper Twin C at McGraw (HBM) & DCBMSR \\
\hline & OHIO BRUSH CREEK BASIN & \\
\hline 03237500 & Ohio Brush C nr West Union & $\mathrm{D}$ \\
\hline
\end{tabular}


SURFACE-WATER STATIONS-Continued

\begin{tabular}{|c|c|c|}
\hline $\begin{array}{l}\text { Station } \\
\text { number }\end{array}$ & Station & $\begin{array}{c}\text { Type of } \\
\text { data }\end{array}$ \\
\hline & WHITEOAK CREEK BASIN & \\
\hline \multirow[t]{2}{*}{03238500} & Whiteoak C nr Georgetown & $\mathrm{D}$ \\
\hline & LITTLE MIAMI RIVER BASIN & $\mathrm{D}$ \\
\hline 03240000 & L Miami $\mathrm{R}$ nr Oldtown & $\mathrm{D}$ \\
\hline 03241500 & Massies $\mathrm{C}$ at Wilberforce & $\mathrm{D}$ \\
\hline 03245500 & L Miami R at Milford (NASQAN) & DCBTS \\
\hline 03247050 & E F L Miami R nr Batavia & $\mathrm{D}$ \\
\hline \multirow[t]{2}{*}{03247500} & E F L Miami R at Perintown & $\mathrm{D}$ \\
\hline & MIAMI CREEK BASIN & \\
\hline \multirow[t]{3}{*}{03259000} & Mill $\mathrm{C}$ at Carthage & $\mathrm{D}$ \\
\hline & GREAT MIAMI RIVER BASIN & \\
\hline & G Miami R: & \\
\hline 03260700 & Bokengehalas C nr De Graff & $\mathrm{D}$ \\
\hline 03261500 & G Miami $R$ at Sidney & $\mathrm{D}$ \\
\hline 03261950 & Loramie C nr Newport & $\mathrm{D}$ \\
\hline 03262000 & Loramie $\mathrm{C}$ at Lockington & $\mathrm{D}$ \\
\hline 03262700 & G Miami $R$ at Troy & $\mathrm{D}$ \\
\hline \multirow[t]{2}{*}{03263000} & G Miami R at Taylorsville & $\mathrm{D}$ \\
\hline & Stillwater R: & \\
\hline 03264000 & Greenville C nr Bradford & $\mathrm{D}$ \\
\hline 03265000 & Stillwater $\mathrm{R}$ at Pleasant Hill & $\mathrm{D}$ \\
\hline 03266000 & Stillwater R at Englewood & $\mathrm{D}$ \\
\hline 03267000 & Mad $R$ at Urbana & $\mathrm{D}$ \\
\hline 03267900 & Mad R (at St. Paris Pike) at Eagle City & $\mathrm{D}$ \\
\hline 03269500 & Mad R nr Springfield & $\mathrm{D}$ \\
\hline
\end{tabular}




\section{SURFACE-WATER STATIONS-Continued}

\begin{tabular}{|c|c|c|}
\hline $\begin{array}{l}\text { Station } \\
\text { number }\end{array}$ & Station & $\begin{array}{c}\text { Type of } \\
\text { data }\end{array}$ \\
\hline 03270000 & Mad R nr Dayton & $\mathrm{D}$ \\
\hline 03270500 & G Miami $R$ at Dayton & $\mathrm{D}$ \\
\hline 03271000 & Wolf $\mathrm{C}$ at Dayton & $\mathrm{D}$ \\
\hline 03271500 & G Miami $R$ at Miamisburg & $\mathrm{D}$ \\
\hline 03271510 & G Miami R nr Linden Ave at Miamisburg & M \\
\hline 03271601 & G Miami R nr bl Miamisburg & $\mathrm{D}$ \\
\hline 03271800 & Twin C nr Ingomar & $\mathrm{D}$ \\
\hline \multirow[t]{2}{*}{03272000} & Twin C nr Germantown & $\mathrm{D}$ \\
\hline & Sevenmile C: & \\
\hline 03272700 & Sevenmile $\mathrm{C}$ at Camden & $\mathrm{D}$ \\
\hline 03274000 & G Miami $R$ at Hamilton & $\mathrm{D}$ \\
\hline 03274600 & G Miami R at New Baltimore (NASQAN) & CBTS \\
\hline \multicolumn{3}{|c|}{$\begin{array}{c}\text { ST. LAWRENCE RIVER BASIN } \\
\text { (STREAMS TRIBUTARY TO LAKE ERIE) }\end{array}$} \\
\hline 04177000 & Ottawa $\mathrm{R}$ at Toledo University & $\mathbf{D}$ \\
\hline 04185000 & Tiffin $R$ at Stryker & $\mathrm{D}$ \\
\hline 04185440 & Lost C nr Farmer & $\mathrm{D}$ \\
\hline 04186500 & Auglaize R nr Ft Jennings & $\mathrm{D}$ \\
\hline 04187100 & Ottawa $R$ at Lima & D \\
\hline 04189000 & Blanchard $R$ nr Findlay & $\mathrm{D}$ \\
\hline 04191500 & Auglaize R nr Defiance & $\mathbf{D}$ \\
\hline 04192500 & Maumee R nr Defiance & $\mathbf{D}$ \\
\hline
\end{tabular}




\section{SURFACE-WATER STATIONS-Continued}

\begin{tabular}{|c|c|c|}
\hline $\begin{array}{l}\text { Station } \\
\text { number }\end{array}$ & Station & $\begin{array}{l}\text { Type of } \\
\text { data }\end{array}$ \\
\hline 04193500 & Maumee $\mathrm{R}$ at Waterville (NASQAN) & DCBTS \\
\hline \multirow[t]{2}{*}{04195500} & Portage $R$ at Woodville & $\mathrm{D}$ \\
\hline & SANDUSKY RIVER BASIN & \\
\hline 04196800 & Tymochtee $\mathrm{C}$ at Crawford & $\mathrm{D}$ \\
\hline 04197100 & Honey $\mathrm{C}$ at Melmore & $\mathrm{D}$ \\
\hline 04197170 & Rock $\mathrm{C}$ at Tiffin & $\mathrm{D}$ \\
\hline 04198000 & Sandusky R nr Fremont (NASQAN) & DCMBTS \\
\hline 04199000 & Huron $R$ at Milan & DSC \\
\hline 04199155 & Old Woman's C at Berlin Road & $\mathrm{D}$ \\
\hline 04199165 & Old Woman's C at U.S. $6 \mathrm{nr}$ Huron & $\mathrm{E}$ \\
\hline 04199175 & Lake Erie at Ruggles Beach & $\mathrm{E}$ \\
\hline 04199287 & Vermilion $\mathrm{R} n \mathrm{n}$ Fitchville & $\mathrm{D}$ \\
\hline 04200500 & Black R at Elyria & $\mathrm{D}$ \\
\hline 04201500 & Rocky R nr Berea & $\mathrm{D}$ \\
\hline 04202000 & Cuyahoga $R$ at Hiram Rapids & $\mathrm{D}$ \\
\hline 04206000 & Cuyahoga $R$ at Old Portage & $\mathrm{D}$ \\
\hline 04207200 & Tinkers $\mathrm{C}$ at Bedford & $\mathrm{D}$ \\
\hline 04208000 & Cuyahoga $R$ at Independence (NASQAN) & DCMTS \\
\hline 04208504 & Cuyahoga R at LTV Steel, Cleveland & $\mathrm{D}$ \\
\hline 04209000 & Chagrin $\mathrm{R}$ at Willoughby & $\mathrm{D}$ \\
\hline 04212100 & Grand R nr Painesville & DSC \\
\hline 04212200 & Grand $R$ at Painesville (NASQAN) & $\mathrm{CT}$ \\
\hline 04213000 & Conneaut $\mathrm{C}$ at Conneaut & $\mathrm{D}$ \\
\hline
\end{tabular}




\section{GROUND-WATER STATIONS FOR WHICH RECORDS ARE PUBLISHED}

The following table is a list of ground-water stations in Ohio for which the U.S. Geological Survey is publishing data in 1993. The first digits of the well numbers denote degrees, minutes, and seconds of latitude, and the next seven digits denote degrees, minutes, and seconds of longitude. The last two digits are used, if needed, for sequential numbering within a 1-second grid.

In addition to the sites listed, data on water levels, yield, and chemical quality of ground water have been collected at many other locations in Ohio. Information about these miscellaneous measurements is available upon request. 


\section{GROUND-WATER STATIONS_Continued}

(Letter after station location designates type of data:

$\mathrm{c}=$ chemical; 1 = water level)

\begin{tabular}{|c|c|c|}
\hline Well number & Local number & Location \\
\hline & & ASHILAND COUNTY \\
\hline 405303082170700 & AS-2 & Ashland (1) \\
\hline \multirow[t]{2}{*}{405425082173000} & AS-3 & Jerome Fork (1) \\
\hline & & ATHENS COUNTY \\
\hline 392004082071600 & AT-2A & Athens (1) \\
\hline \multirow[t]{2}{*}{392009082072200} & AT-5 & Athens (1) \\
\hline & & AUGLAIZE COUNTY \\
\hline \multirow[t]{2}{*}{403233083574500} & AU-3 & $\begin{array}{l}\text { Southwest of New } \\
\text { Hampshire (1) }\end{array}$ \\
\hline & & BELMONT COUNTY \\
\hline \multirow[t]{2}{*}{400118081082200} & B-3 & Mount Oliver (1) \\
\hline & & BROWN COUNTY \\
\hline \multirow[t]{2}{*}{385932083412400} & BR-2 & Fincastle (1) \\
\hline & & BUTLER COUNTY \\
\hline 391805084261800 & BU-9 & Northwest of Sharonville (l) \\
\hline 391904084371800 & BU-12 & East of Rose \\
\hline 392017084345200 & BU-7 & Fairfield (1) \\
\hline 392048084311400 & BU-8 & East of Hamilton (1) \\
\hline 392445084333000 & BU-36 & Hamilton (c) \\
\hline 393202084241500 & BU-15 & Middletown (1) \\
\hline 392737084291300 & BU-16 & Southwest of Trenton (1) \\
\hline 392743084295500 & BU-17 & Near Trenton (1) \\
\hline 392939084231700 & BU-3 & Middletown (1) \\
\hline
\end{tabular}




\section{GROUND-WATER STATIONS-Continued}

\begin{tabular}{|c|c|c|}
\hline Well number & Local number & Location \\
\hline & & BUTLER COUNIY \\
\hline \multirow[t]{2}{*}{393103084240900} & $\mathrm{BU}-2$ & Middletown (1) \\
\hline & & CARROL COUNTY \\
\hline \multirow[t]{2}{*}{403709081052800} & $\mathrm{C}-1$ & North of Carrolton (1) \\
\hline & & CHAMPAIGN COUNTY \\
\hline \multirow[t]{2}{*}{400638083453900} & $\mathrm{CH}-3$ & Urbana (1) \\
\hline & & CLARK COUNTY \\
\hline 39563908401220 & CL-9 & New Carlisle (1) \\
\hline \multirow[t]{2}{*}{395840083495200} & CL-7 & Northwest of Springfield (1) \\
\hline & & COSHOCTON COUNTY \\
\hline 401256081525100 & CS-3 & North of Conesville (l) \\
\hline \multirow[t]{2}{*}{401735081523800} & CS-2 & Coshocton \\
\hline & & CRAWFORD COUNTY \\
\hline \multirow[t]{2}{*}{404838082563100} & CR-1 & Bucyrus (1) \\
\hline & & DARKE COUNTY \\
\hline \multirow[t]{2}{*}{400514084345700} & $\mathrm{D}-2$ & East of Greenville (1) \\
\hline & & DELAWARE COUNTY \\
\hline \multirow[t]{2}{*}{402126083040400} & DL-3 & Delaware (1) \\
\hline & & FAIRFIELD COUNTY \\
\hline 393450082403600 & F-7 & Southeast of Amanda (1) \\
\hline 394257082362900 & F-6 & Lancaster (l) \\
\hline 394544082271000 & F-1 & West Rushville (1) \\
\hline \multirow[t]{2}{*}{395053082361900} & F-5 & Baltimore (1) \\
\hline & & FAYETTE COUNTY \\
\hline 393153083322000 & FA-1 & $\begin{array}{c}\text { West of Washington Court } \\
\text { House (1) }\end{array}$ \\
\hline
\end{tabular}




\section{GROUND-WATER STATIONS-Continued}

\begin{tabular}{|c|c|c|}
\hline Well number & Local number & Location \\
\hline & & FRANKLIN COUNTY \\
\hline 394956083002700 & FR-18 & Shadeville (1) \\
\hline 395118082573300 & FR-3 & Southwest of Rees (1) \\
\hline \multirow[t]{2}{*}{400101083021800} & FR-10 & Columbus (1) \\
\hline & & GALLIA COUNTY \\
\hline \multirow[t]{2}{*}{383638082103300} & G-2 & East of Crown City (1) \\
\hline & & GREENE COUNTY \\
\hline 394330083531400 & GR-11 & Near Wilberforce (1) \\
\hline 394411083561300 & GR-1 & North of Xenia (1) \\
\hline \multirow[t]{2}{*}{394425083551100} & GR-10 & North of Xenia (1) \\
\hline & & HAMILTON COUNTY \\
\hline 391039084291500 & H-11 & Cincinnati (1) \\
\hline 391101084172100 & $\mathrm{H}-3$ & Southeast of Miamiville \\
\hline 391201084281600 & H-10 & Cincinnati (1) \\
\hline 391214084470100 & $\mathrm{H}-1$ & Southeast of Harrison (1) \\
\hline 391324084272500 & H-9 & Cincinnati (1) \\
\hline 391341084275300 & $\mathrm{H}-8$ & Wyoming (1) \\
\hline 391442084262900 & $\mathrm{H}-7$ & Evendale (1) \\
\hline 391608084254400 & H-6 & Glendale (1) \\
\hline 391733084392400 & $\mathrm{H}-2$ & South of Ross (1) \\
\hline 391748084393800 & $\mathrm{H}-19$ & Southwest of Venice (c) \\
\hline \multirow[t]{2}{*}{391817084393300} & $\mathrm{H}-4$ & Southwest of Ross (1) \\
\hline & & HANCOCK COUNTY \\
\hline \multirow[t]{2}{*}{405940083275500} & HA-3 & South of Vanlue (1) \\
\hline & & HARDIN COUNTY \\
\hline 404218083503700 & $\mathrm{HN}-1$ & Alger (1) \\
\hline
\end{tabular}




\begin{tabular}{|c|c|c|}
\hline Well number & Local number & Location \\
\hline & & HARDIN COUNTY \\
\hline \multirow[t]{2}{*}{4046480834012600} & $\mathrm{HN}-2 \mathrm{~A}$ & Southeast of Dola (1) \\
\hline & & HENRY COUNTY \\
\hline \multirow[t]{2}{*}{412123083574000} & $\mathrm{HY}-2$ & Southwest of McClure (1) \\
\hline & & HOCKING COUNTY \\
\hline \multirow[t]{2}{*}{393200082235300} & HK-1 & Logan (1) \\
\hline & & KNOX COUNTY \\
\hline \multirow[t]{2}{*}{402344082300700} & K-1 & Mt. Vernon (1) \\
\hline & & LICKING COUNTY \\
\hline \multirow{2}{*}{400848082251100} & LI-4 & Near St. Louisville (1) \\
\hline & & LUCAS COUNTY \\
\hline \multirow[t]{2}{*}{413704083362200} & $\mathrm{LU}-1$ & Toledo (1) \\
\hline & & MADISON COUNTY \\
\hline 395301083272200 & M-2 & London (1) \\
\hline 395352083292100 & M-5 & Near London (1) \\
\hline 395357083304400 & M-4 & Northwest of London (1) \\
\hline \multirow[t]{2}{*}{395740083255700} & $\mathrm{M}-3$ & North of London (1) \\
\hline & & MAHONING COUNTY \\
\hline \multirow[t]{2}{*}{410042080453800} & MA-1 & Canfield (1) \\
\hline & & MARION COUNTY \\
\hline 403413083170500 & $\mathrm{MN}-4$ & $\begin{array}{l}\text { Southeast of New } \\
\text { Bloomington (1) }\end{array}$ \\
\hline 403443083230400 & $\mathrm{MN}-1$ & LaRue (1) \\
\hline \multirow[t]{2}{*}{403601083110400} & $\mathrm{MN}-2$ & West of Marion (1) \\
\hline & & MEDINA COUNTYY \\
\hline 410120081431800 & MD-3 & Wadsworth (1) \\
\hline
\end{tabular}




\section{GROUND-WATER STATIONS-Continued}

\begin{tabular}{|c|c|c|}
\hline Well number & Local number & Location \\
\hline & & MEDINA COUNTY \\
\hline \multirow[t]{2}{*}{410142082005900} & MD-1 & Lodi (1) \\
\hline & & MERCER COUNTY \\
\hline \multirow[t]{2}{*}{402833084375200} & MR-2 & Coldwater (1) \\
\hline & & MIAMI COUNIY \\
\hline 395848084085500 & MI-3 & Northeast of Tipp City (1) \\
\hline \multirow[t]{2}{*}{400208084112900} & MI-44 & Troy (c) \\
\hline & & MONTGOMERY COUNTY \\
\hline 393757084173600 & MT-928 & Miamisburg (c) \\
\hline 394012084151700 & MT-55 & West Carrollton (1) \\
\hline 394025084162800 & MT-49 & West Carrollton (1) \\
\hline 394425084113200 & MT-3 & Dayton (lc) \\
\hline 394533084113800 & MT-6 & Dayton (1) \\
\hline \multirow[t]{2}{*}{394811084095000} & MT-74 & Dayton (1) \\
\hline & & MUSKINGUM COUNTY \\
\hline \multirow[t]{2}{*}{395804081593200} & MU-1A & Zanesville (1) \\
\hline & & OTTAWA COUNTY \\
\hline \multirow[t]{2}{*}{413434082494000} & $0-2$ & Catawba Island (1) \\
\hline & & PICKAWAY COUNTY \\
\hline 393327082571600 & PK-7 & South of Circleville (1) \\
\hline 393402082572500 & PK-4 & South of Circleville (1) \\
\hline 393638082572300 & PK-6 & Northwest of Circleville (1) \\
\hline 393438083072200 & PK-8 & Williamsport (1) \\
\hline \multirow[t]{2}{*}{394742083094800} & PK-9 & Near Orient (1) \\
\hline & & PIKE COUNTY \\
\hline 390359083015100 & PI-2 & West of Piketon (1) \\
\hline
\end{tabular}




\section{GROUND-WATER STATIONS—Continued}

\begin{tabular}{|c|c|c|}
\hline Well number & Local number & Location \\
\hline & & PORTAGE COUNTY \\
\hline \multirow[t]{2}{*}{411401081025000} & $\mathrm{PO}-1$ & Windam (1) \\
\hline & & PREBLE COUNTY \\
\hline \multirow[t]{2}{*}{394438084335900} & PR-2 & East of Eaton (1) \\
\hline & & PUTNAM COUNTY \\
\hline \multirow[t]{2}{*}{405505084032900} & PU-1 & Columbus Grove (1) \\
\hline & & RICHLAND COUNTY \\
\hline 404625082305100 & $\mathrm{R}-4$ & Mansfield (1) \\
\hline \multirow[t]{2}{*}{405753082360800} & $\mathrm{R}-3$ & Shiloh (l) \\
\hline & & ROSS COUNTY \\
\hline 391341083172200 & $\mathrm{RO}-7$ & West of Bainbridge (1) \\
\hline \multirow[t]{2}{*}{391913082580500} & $\mathrm{RO}-8$ & Chillicothe (1) \\
\hline & & SANDUSKY COUNTY \\
\hline 411914083045300 & S-3 & Fremont (1) \\
\hline \multirow[t]{2}{*}{41270383213600} & S-2 & Woodville (l) \\
\hline & & SENECA COUNTY \\
\hline \multirow[t]{2}{*}{410802083093900} & SE-2 & Tiffin (1) \\
\hline & & SHELBY COUNTY \\
\hline \multirow[t]{2}{*}{401712084103500} & $\mathrm{SH}-4$ & Sidney (1) \\
\hline & & STARK COUNTY \\
\hline 404939081203800 & ST-5A & Canton (1) \\
\hline \multirow[t]{2}{*}{405211081253500} & ST-27 & North Canton (1) \\
\hline & & SUMMIT COUNTY \\
\hline 410330081282000 & SU-6 & Akron (1) \\
\hline 410846081271600 & SU-7 & Cuyahoga Falls (1) \\
\hline
\end{tabular}




\section{GROUND-WATER STATIONS-Continued}

\begin{tabular}{|c|c|c|}
\hline Well number & Local number & Location \\
\hline & & TRUMBULL COUNTY \\
\hline \multirow[t]{2}{*}{411604080505600} & $\mathrm{~T}-3$ & Near Warren (1) \\
\hline & & TUSCARAWAS COUNTY \\
\hline 403207081293800 & TU-3 & Dover (1) \\
\hline 403557081313600 & TU-4 & Strasburg (1) \\
\hline 403653081321800 & TU-1 & North of Strasburg (1) \\
\hline \multirow[t]{2}{*}{403823081324200} & TU-5 & Near Strasburg (1) \\
\hline & & UNION COUNTY \\
\hline 401826083255200 & U-4 & Southeast of Raymond (1) \\
\hline \multirow[t]{2}{*}{402010083321900} & U-5 & East of Liberty (l) \\
\hline & & VAN WERT COUNTY \\
\hline \multirow[t]{2}{*}{405215084335400} & VW-1 & Van Wert (1) \\
\hline & & VINTON \\
\hline \multirow[t]{2}{*}{391452082282900} & $\mathrm{~V}-1$ & McArthur (1) \\
\hline & & WARREN COUNTY \\
\hline \multirow[t]{2}{*}{392712084191700} & W-5 & East of Monroe (1) \\
\hline & & WASHINGTON COUNTY \\
\hline 392553081281600 & WA-2 & Marietta (1) \\
\hline \multirow[t]{2}{*}{393241081353500} & WA-3 & Near Beverly (1) \\
\hline & & WAYNE COUNTY \\
\hline 404655081553200 & $\mathrm{WN}-3$ & Near Wooster (1) \\
\hline 404802081583100 & $\mathrm{WN}-2 \mathrm{~A}$ & Near Wooster (1) \\
\hline 405745081510200 & WN-7 & Near Sterling (1) \\
\hline 405805081462300 & $\mathrm{WN}-6$ & Rittman (1) \\
\hline
\end{tabular}




\section{GROUND-WATER STATIONS-Continued}

\begin{tabular}{|c|c|c|}
\hline Well number & Local number & Location \\
\hline & & WILLIAMS COUNTY \\
\hline 412821084313600 & WM-1 & Near Bryan (1) \\
\hline 412930084320900 & WM-3 & Bryan (1) \\
\hline 413108084415300 & WM-12 & East of Blakeslee (1) \\
\hline & & WYANDOT COUNTY \\
\hline 405009083172600 & WY-1 & Upper Sandusky (l) \\
\hline
\end{tabular}




\section{SELECTED REFERENCES ON OHIO HYDROLOGY}

Selected references on water resources in Ohio are listed below; many of them are available for inspection at the Ohio District office and at large public and university libraries. The publications are grouped as follows (1) alphabetized by county; and (2) alphabetized by author.

\section{ALLEN COUNTY:}

Webber, E. E., 1982, Flood of June 13-15, 1981, in the Blanchard River Basin, northwestern Ohio:U. S. Geological Survey Water-Resources Investigations Report 82-4044.

\section{ASHLAND COUNTY:}

Norris, S. E., 1963, Hydrogeology of a spring in a glacial terrane near Ashland, Ohio: U. S. Geological Survey Water-Supply Paper 1619-A.

\section{ASHTABULA COUNTY:}

Coen, A. W., III, 1990, Ground-water levels, flow, and specific conductance in unconsolidated aquifers near Lake Erie, Cleveland to Conneaut, Ohio, September 1984: U. S. Geological Survey Water-Resources Investigations Report 89-4202.

Norris, S. E., 1978, The Silurian salt deposits in eastern Lake, northwestern Ashtabula, and northeastern Geauga Counties, Ohio: U. S. Geological Survey Open-File Report 79-269.

\section{ATHENS COUNTY:}

Childress, C. J. Oblinger, and Jones, R. L., 1985, Sedimentation and water quality in the West Branch Shade River Basin, Ohio, 1984 water year: U. S. Geological Survey Open-File Report 85-552.

Childress, C. J. Oblinger, and Jones, R. L., 1988, Sedimentation and water quality in the West Branch Shade River Basin, Ohio, 1983-85: U. S. Geological Survey Water-Resources Investigations Report 87-4262.

Hindall, S. M., 1984, Effects of surface coal-mine reclamation on stream quality in a small watershed near Nelsonville, southeastern Ohio: U. S. Geological Survey WaterResources Investigations Report 84-4179.

Mayo, R. I., and Webber, E. E., 1969, Floods at Amesville (Athens County), Ohio: U. S. Geological Survey Circular 324.

Wilson, K. S., 1985, Surface-water quality of coal-mine lands in Raccoon Creek Basin, Ohio: U. S. Geological Survey Water-Resources Investigations Report 85-4060.

Wilson, K. S., 1988, Chemical quality, benthic organisms, and sedimentation in streams draining coal-mined lands in Raccoon Creek Basin, Ohio, July 1984 through September 1986: U. S. Geological Survey Water-Resources Investigations Report 88-4022.

\section{BELMONT COUNTY:}

Koltun, G. F., 1988, Analysis of postdredging bed-level changes in selected reaches of Wheeling Creek, eastern Ohio, 1985-87: U. S. Geological Survey Water-Resources Investigations Report 88-4119. 


\section{BELMONT COUNTY-Continued:}

Kolva, J. R., and Koltun, G. F., 1987, Flooding and sedimentation in Wheeling Creek Basin, Belmont County, Ohio: U. S. Geological Survey Water-Resources Investigations Report 87-4053.

Shindel, H. L., 1991, Flood of June 14-15, 1990, in Belmont, Jefferson, and Harrison Counties, Ohio, with emphasis on Pipe and Wegee Creek Basins near Shadyside: U. S. Geological Survey Water-Resources Investigations Report 91-4147, 33 p.

\section{BUTLER COUNTY:}

Dove, G. D., 1961, A hydrologic study of the valley-fill deposits in the Venice area (Butler County), Ohio: Ohio Department of Natural Resources, Division of Water Technical Report 4.

Fidler, R. E., 1970, Potential development and recharge of ground water in Mill Creek valley, Butler and Hamilton Counties, Ohio, based on analog model analysis: U. S. Geological Survey Water-Supply Paper 1893.

Klaer, F. H., Jr., and Thompson, D. G., 1948, Ground-water resources of the Cincinnati area, Butler and Hamilton Counties, Ohio: U. S. Geological Survey Water-Supply Paper 999.

\section{CHAMPAIGN COUNTY:}

Feulner, A. J., 1960, The ground-water resources of Champaign County, Ohio: unnumbered U. S. Geological Survey Open-File Report.

Feulner, A. J., 1961, Cyclic-fluctuation methods for determining permeability as applied to valley train in the Mad River Valley in Champaign County, Ohio: Ohio Journal of Science, v. 61 , no. 2 , p. 99-106.

Feulner, A. J., and Hubble, J. H., 1960, Occurrence of strontium in the surface and ground waters of Champaign County, Ohio: Economic Geology, v. 55, no. 1, p. 176-186.

\section{CLARK COUNTY:}

Cross, W. P., and Feulner, A. J., 1963, Anomalous streamflow-ground-water regimen in the Mad River Basin, near Springfield, Ohio: U. S. Geological Survey Professional Paper 475-D. Edelen, G. W., Jr., Ruggles, F. H., Jr., and Cross, W. P., 1961, Floods at Springfield (Clark County), Ohio, in 1913 and 1959: U. S. Geological Survey Hydrologic Investigations Atlas 43.

Mayo, R. I., 1977, Hydrologic analysis, Mad River at State Highway 41, Springfield, Ohio: U. S. Geological Survey Open-File Report 77-399.

Norris, S. E., 1951, The bedrock surface and the distribution of the consolidated rocks in Montgomery, Greene, Clark, and Madison Counties, Ohio: Ohio Journal of Science, v. 51, no. 1 , p. 13-15.

Norris, S. E., Cross, W. P., Goldthwait, R. P., and Sanderson, E. E., 1952, The water resources of Clark County, Ohio: Ohio Department of Natural Resources, Division of Water Bulletin 22.

Norris, S. E., and Eagon, H. B., Jr., 1971, Recharge characteristics of a watercourse aquifer system at Springfield (Clark County), Ohio: Ground Water, v. 4, no. 3, p. 43-48.

\section{CLINTON COUNTY:}

Evans, K. F., and Tobin, R. L., 1979, Water-quality assessment of Rattlesnake Creek watershed, Ohio: U. S. Geological Survey Water-Resources Investigations Report 79-17. 


\section{COLUMBIANA COUNTY:}

Koltun, G. F., and HeIseI, D. R., 1986, Influence of size-fractioning techniques on concentrations of selected trace metals in bottom materials from two streams in northeastern Ohio:

U. S. Geological Survey Water-Resources Investigations Report 86-4114.

\section{COSHOCTON COUNTY:}

Eberle, MichaeI, and Razem, A. C., 1985, Effects of surface coal mining and reclamation on ground water in small watersheds in the Allegheny Plateau, Ohio: U. S. Geological Survey Water-Resources Investigations Report 85-4205.

Helgesen, J. O., and Razem, A. C., 1981, Ground-water hydrology of strip-mine areas in eastern Ohio (Conditions during mining of two watersheds in Coshocton and Muskingum Counties): U. S. Geological Survey Open-File Report 81-913.

Razem, A. C., 1983, Ground-water hydrology before, during, and after coal strip mining of a small watershed in Coshocton County, Ohio: U. S. Geological Survey Water-Resources Investigations Report 83-4155.

Westfall, A. O., and Webber, E. E., 1977, Time of travel of solutes in the Tuscarawas River basin, Ohio, August and September 1974: U. S. Geological Survey Water-Resources Investigations Report 77-23.

\section{CRAWFORD COUNTY:}

Mayo, R. I., and Mangus, J. P., 1989, Flood of July 1-2, 1987, in north-central Ohio:

U. S. Geological Survey Open-File Report 89-376.

\section{CUYAHOGA COUNTY:}

Coen, A. W., III., 1990, Ground-water levels, flow, and specific conductance in unconsolidated aquifers near Lake Erie, Cleveland to Conneaut, Ohio, September 1984: U. S. Geological Survey Water-Resources Investigations Report 89-4202.

Schroeder, M. E., and Collier, C. R., 1966, Water-quality variations in the Cuyahoga River at Cleveland, Ohio: U. S. Geological Survey Professional Paper 550-C.

White, G. W., 1953, Sangamon soil and early Wisconsin loesses at Cleveland (Cuyahoga County), Ohio: American Journal of Science, v. 251, no. 5, p. 362-368.

Winslow, J. D., White, G. W., and Webber, E. E., 1953, The water resources of Cuyahoga County, Ohio: Ohio Department of Natural Resources, Division of Water Bulletin 26.

\section{FAIRFIELD COUNTY:}

Hren, Janet, and Jones, R. L., 1982, Potential impacts of a proposed reservoir on hydrologic and water-quality conditions in Little Rush Creek watershed, Fairfield County, Ohio:

U. S. Geological Survey Open-File Report 82-109.

Norris, S. E., 1967, Effects on ground-water quality and induced infiltration of wastes disposed into the Hocking River at Lancaster (Fairfield County), Ohio: Ground Water, v. 5, no. 3, p. 15-19.

Norris, S. E., and Mayer, G. C., 1982, Water resources of the Black Hand Sandstone Member of the Cuyahoga Formation and associated aquifers of Mississippian age in southeastern Ohio: U. S. Geological Survey Open-File Report 82-170. 


\section{FAYETTE COUNTY:}

Evans, K. F., and Tobin, R. L., 1979, Water-quality assessment of Rattlesnake Creek watershed, Ohio: U. S. Geological Survey Water-Resources Investigations Report 79-17.

\section{FRANKLIN COUNTY:}

Childress, C. J. O., Sheets, R. A., and Bair, E. S., 1991, Hydrology and water quality near the south well field, southern Franklin County, Ohio, with emphasis on the simulation of ground-water flow and transport of Scioto River: U. S. Geological Survey Water-Resources Investigations Report 91-4080.

de Roche, J. T., 1985, Hydrogeology and effects of landfills on ground-water quality, southern Franklin County, Ohio: U. S. Geological Survey Water-Resources Investigations Report 85-4222.

de Roche, J. T., and Razem, A. C., 1981, Ground-water quality in the vicinity of landfill sites, southern Franklin County, Ohio: U. S. Geological Survey Open-File Report 81-919.

de Roche, J. T., and Razem, A. C., 1984, Water quality of a stream-aquifer system, southern Franklin County, Ohio: U. S. Geological Survey Water-Resources Investigations Report 84-4238.

Eberts, S. M., and Bair, E. S., 1987, Effects of quarry dewatering on ground-water levels and landfill-leachate migration, southern Franklin County, Ohio, in 32nd Annual Midwest Ground Water Conference, Program with Abstracts: p. 9.

Edelen, G. W., Jr., Ruggles, F. H., Jr., Somers, W. P., and Cross, W. P., 1962, Floods at Columbus (Franklin County), Ohio: U. S. Geological Survey Hydrologic Investigations Atlas 52.

Helsel, D. R., 1985, Contributions of suspended sediment by highway construction and other land uses to the Olentangy River, Columbus, Ohio: U. S. Geological Survey Water-Resources Investigations Report 84-4336.

Myers, D. N., 1993, Distribution and variability of fecal-indicator bacteria in the Scioto and Olentangy Rivers in the Columbus, Ohio area: U. S. Geological Survey WaterResources Investigations Report 92-4130.

Norris, S. E., 1959, Buried topography and its relation to an important aquifer in Franklin County, Ohio: Ohio Journal of Science, v. 59, no. 6, p. 341-343.

Razem, A. C., 1983, Simulations of nonsteady flow in a glacial-outwash aquifer, southern Franklin County, Ohio: U. S. Geological Survey Water-Resources Investigations Report 83-4022.

Sedam, A. C., Eberts, S. M., and Bair, E. S., 1989, Ground-water levels, water quality, and potential effects of toxic-substance spills or cessation of quarry dewatering near a municipal ground-water supply, southern Franklin County, Ohio: U. S. Geological Survey Water-Resources Investigations Report 88-4138.

Schmidt, J. J., 1958, The ground-water resources of Franklin County, Ohio: Ohio Department of Natural Resources, Division of Water Bulletin 30.

Weiss, E. J., and Razem, A. C., 1980, A model for flow through a glacial-outwash aquifer in southeast Franklin County, Ohio: U. S. Geological Survey Water-Resources Investigations Report 80-56. 


\section{GALLIA COUNTY:}

Mayo, R. I., and Webber, E. E., 1981, Flood of August 20, 1979, on a tributary of Chickamauga

Creek, near Gallipolis, Ohio: U. S. Geological Survey Open-File Report 81-414.

Wilson, K. S., 1985, Surface-water quality of coal-mine lands in Raccoon Creek Basin, Ohio:

U. S. Geological Survey Water-Resources Investigations Report 85-4060.

Wilson, K. S., 1988, Chemical quality, benthic organisms, and sedimentation in streams draining coal-mined lands in Raccoon Creek Basin, Ohio, July 1984 through September 1986:

U. S. Geological Survey Water-Resources Investigations Report 88-4022.

\section{GEAUGA COUNTY:}

Eberts, S. M., Bair, E. S., and de Roche, J. T., 1990, Geohydrology, ground-water quality, and simulated ground-water flow, Geauga County, Ohio: U. S. Geological Survey

Water-Resources Investigations Report 90-4026.

Nichols, V. E., 1980, Ground-water conditions in Geauga County, Ohio, 1978:

U. S. Geological Survey Water-Resources Investigations Report 80-28.

Norris, S. E., 1978, The Silurian salt deposits in eastern Lake, northwestern Ashtabula, and northeastern Geauga Counties, Ohio: U. S. Geological Survey Open-File Report 79-269.

\section{GREENE COUNTY:}

Evans, K. F., and Tobin, R. L., 1979, Water-quality assessment of Rattlesnake Creek watershed, Ohio: U. S. Geological Survey Water-Resources Investigations Report 79-17.

Norris, S. E., 1950, The water resources of Greene County, Ohio: Ohio Department of Natural Resources, Division of Water Bulletin 19.

Norris, S. E., 1951, The bedrock surface and the distribution of the consolidated rocks in Montgomery, Greene, Clark, and Madison Counties, Ohio: Ohio Journal of Science, v. 51, no. 1, p. 13-15.

Walton, W. C., and Scudder, G. D., 1960, Ground-water resources of the valley-train deposits in the Fairborn area (Greene County), Ohio: Ohio Department of Natural Resources, Division of Water Technical Report 3.

\section{HAMILTON COUNTY:}

Bauer, D. P., 1968, Time of travel of water in the Great Miami River, Dayton to Cleves, Ohio: U. S. Geological Survey Circular 546.

Fidler, R. E., 1970, Potential development and recharge of ground water in Mill Creek valley, Butler and Hamilton Counties, Ohio, based on analog model analysis: U. S. Geological Survey Water-Supply Paper 1893.

Klaer, F. H., Jr., and Thompson, D. G., 1948, Ground-water resources of the Cincinnati area, Butler and Hamilton Counties, Ohio: U. S. Geological Survey Water-Supply Paper 999.

Sedam, A. C., 1984, Occurrence of uranium in ground water in the vicinity of the U. S. Department of Energy Feed Materials Production Center, Fernald, Ohio:

U. S. Geological Survey Open-File Report 85-099.

Spieker, A. M., 1968, Effects of increased pumping of ground water in the Fairfield-New Baltimore area (Hamilton County), Ohio-A prediction by analog-model study:

U. S. Geological Survey Professional Paper 605-C. 


\section{HANCOCK COUNTY:}

Webber, E. E., 1982, Flood of June 13-15, 1981, in the Blanchard River Basin, northwestern Ohio:U. S. Geological Survey Water-Resources Investigations Report 82-4044.

\section{HARDIN COUNTY:}

Walton, W. C., 1953, The hydraulic properties of a dolomite aquifer underlying the village of Ada (Hardin County), Ohio: Ohio Department of Natural Resources, Division of Water Technical Report 1.

Webber, E. E., 1982, Flood of June 13-15, 1981, in the Blanchard River Basin, northwestern Ohio:U. S. Geological Survey Water-Resources Investigations Report 82-4044.

\section{HARRISON COUNTY:}

Bartlett, W. P., Jr., and others, 1984, Effects of relocating State Route 151 on the flood profiles of Conotton Creek and its tributaries between Bowerston and Scio, Ohio: U. S. Geological Survey Water-Resources Investigations Report 83-4130.

Koltun, G. F., 1988, Analysis of postdredging bed-level changes in selected reaches of Wheeling Creek, eastern Ohio, 1985-87: U. S. Geological Survey Water-Resources Investigations Report 88-4119.

Shindel, H. L., 1991, Flood of June 14-15, 1990, in Belmont, Jefferson, and Harrison Counties, Ohio, with emphasis on Pipe and Wegee Creek Basins near Shadyside: U. S. Geological Survey Water-Resources Investigations Report 91-4147, 33 p.

\section{HIGHLAND COUNTY:}

Cross, W. P., 1966, Flood of July 23, 1965, in the vicinity of Hillsboro (Highland County), Ohio: Ohio Department of Natural Resources, Division of Water Miscellaneous Report 16.

Evans, K. F., and Tobin, R. L., 1979, Water-quality assessment of Rattlesnake Creek watershed, Ohio: U. S. Geological Survey Water-Resources Investigations Report 79-17.

Stabler, Herman, 1906, Prevention of stream pollution by distillery refuse, based on investigations at Lynchburg, Ohio: U. S. Geological Survey Water-Supply Paper 179.

\section{HOCKING COUNTY:}

Flint, R. F., 1972, Fluvial sediment in Hocking River subwatershed 1 (North Branch Hunters Run, Hocking County), Ohio: U. S. Geological Survey Water-Supply Paper 1798-I.

Norris, S. E., and Mayer, G. C., 1982, Water resources of the Black Hand Sandstone Member of the Cuyahoga Formation and associated aquifers of Mississippian age in southeastern Ohio: U. S. Geological Survey Open-File Report 82-170.

Wilson, K. S., 1985, Surface-water quality of coal-mine lands in Raccoon Creek Basin, Ohio: U. S. Geological Survey Water-Resources Investigations Report 85-4060.

Wilson, K. S., 1988, Chemical quality, benthic organisms, and sedimentation in streams draining coal-mined lands in Raccoon Creek Basin, Ohio, July 1984 through September 1986: U. S. Geological Survey Water-Resources Investigations Report 88-4022.

\section{HURON COUNTY:}

Cross, W. P., 1967, Flood of July 12, 1966, in the vicinity of Sandusky (Huron County), Ohio. unnumbered U. S. Geological Survey Open-File Report. 


\section{JACKSON COUNTY:}

Webber, E. E., and Mayo, R. I., 1968, Floods at Jackson (Jackson County), Ohio:

U. S. Geological Survey Hydrologic Investigations Atlas 325.

Wilson, K. S., 1985, Surface-water quality of coal-mine lands in Raccoon Creek Basin, Ohio:

U. S. Geological Survey Water-Resources Investigations Report 85-4060.

Wilson, K. S., 1988, Chemical quality, benthic organisms, and sedimentation in streams draining coal-mined lands in Raccoon Creek Basin, Ohio, July 1984 through September 1986:

U. S. Geological Survey Water-Resources Investigations Report 88-4022.

\section{JEFFERSON COUNTY:}

Cunningham, W. L., and Jones, R. L., 1990, Long-term effects of surface coal mining on ground-water levels and quality in two small watersheds in eastern Ohio:

U. S. Geological Survey Water-Resources Investigations Report 90-4136.

Eberle, Michael, and Razem, A. C., 1985, Effects of surface coal mining and reclamation on ground water in small watersheds in the Allegheny Plateau, Ohio: U. S. Geological Survey Water-Resources Investigations Report 85-4205.

Hren, Janet, 1986, Changes in ground-water quality resulting from surface coal mining of a small watershed in Jefferson County, Ohio: U. S. Geological Survey Water-Resources Investigations Report 86-4108.

Koltun, G. F., 1988, Analysis of postdredging bed-level changes in selected reaches of Wheeling Creek, eastern Ohio, 1985-87: U. S. Geological Survey Water-Resources Investigations Report 88-4119.

Razem, A. C., 1984, Ground-water hydrology and quality before and after strip mining of a small watershed in Jefferson County, Ohio: U. S. Geological Survey Water-Resources Investigations Report 83-4215.

Shindel, H. L., 1991, Flood of June 14-15, 1990, in Belmont, Jefferson, and Harrison Counties, Ohio, with emphasis on Pipe and Wegee Creek Basins near Shadyside: U. S. Geological Survey Water-Resources Investigations Report 91-4147, 33 p.

\section{KNOX COUNTY:}

Edelen, G. W., Jr., Ruggles, F. H., Jr., and Cross, W. P., 1961 (revised 1964), Floods at Mount Vernon (Knox County), Ohio: U. S. Geological Survey Hydrologic Investigations Atlas 40.

\section{LAKE COUNTY:}

Norris, S. E., 1978, The Silurian salt deposits in eastern Lake, northwestern Ashtabula, and northeastern Geauga Counties: U. S. Geological Survey Open-File Report 79-269.

\section{LICKING COUNTY:}

Dove, G. D., 1960, Water resources of Licking County, Ohio: Ohio Department of Natural Resources, Division of Water Bulletin 36.

Edelen, G. W., Jr., Ruggles, F. H., Jr., and Cross, W. P., 1962 (revised 1964), Floods at Newark (Licking County), Ohio: U. S. Geological Survey Hydrologic Investigations Atlas 44.

Hren, Janet, 1983, Measurement of the reaeration coefficients of the North Fork Licking River at Utica, Ohio, by radioactive tracers: U. S. Geological Survey Water-Resources Investigations Report 83-4192. 


\section{LUCAS COUNTY:}

Breen, K. J., 1989, Potentiometric-surface map of the carbonate aquifer in Silurian and Devonian rocks, Lucas, Sandusky, and Wood Counties, northwestern Ohio, July 1986: U. S. Geological Survey Water-Resources Investigations Report 88-4144.

Breen, K. J., and Dumouchelle, D. H., 1991, Geohydrology and quality of water in Lucas, Sandusky, and Wood Counties, northwestern Ohio: U. S. Geological Survey Water-Resources Investigations Report 91-4024.

\section{MADISON COUNTY:}

Evans, K. F., and Tobin, R. L., 1979, Water-quality assessment of Rattlesnake Creek watershed, Ohio: U. S. Geological Survey Water-Resources Investigations Report 79-17.

Norris, S. E., 1951, The bedrock surface and the distribution of the consolidated rocks in Montgomery, Greene, Clark, and Madison Counties, Ohio: Ohio Journal of Science, v. 51, no. 1, p. 13-15.

Norris, S. E., 1959, The water resources of Madison County, Ohio: Ohio Department of Natural Resources, Division of Water Bulletin 33.

\section{MAHONING COUNTY:}

Cross, W. P., Schroeder, M. E., and Norris, S. E., 1952, Water resources of the Mahoning River Basin, Ohio, with special reference to the Youngstown area: U. S. Geological Survey Circular 177.

Edelen, G. W., Jr., Cross, W. P., and Somers, W. P., 1963, Floods on Crab Creek at Youngstown (Mahoning County), Ohio: U. S. Geological Survey Hydrologic Investigations Atlas 56.

\section{MARION COUNTY:}

Mayo, R. I., and Mangus, J. P., 1989, Flood of July 1-2, 1987, in north-central Ohio:

U. S. Geological Survey Open-File Report 89-376.

Norris, S. E., 1979, Hydraulic properties of a limestone-dolomite aquifer near Marion, northcentral Ohio: Ohio Department of Natural Resources Division of Geological Survey Report of Investigations 110.

Westfall, A. O., 1976, Time of travel of solutes in selected reaches of the Sandusky River basin, Ohio, 1972 and 1973: U. S. Geological Survey Water-Resources Investigations Report 76-50.

\section{MEIGS COUNTY:}

Childress, C. J. Oblinger, and Jones, R. L., 1985, Sedimentation and water quality in the West Branch Shade River Basin, Ohio, 1984 water year: U. S. Geological Survey Open-File Report 85-552.

Childress, C. J. Oblinger, and Jones, R. L., 1988, Sedimentation and water quality in the West Branch Shade River basin, Ohio, 1983-85: U. S. Geological Survey Water-Resources Investigations Report 87-4262.

Wilson, K. S., 1985, Surface-water quality of coal-mine lands in Raccoon Creek basin, Ohio:

U. S. Geological Survey Water-Resources Investigations Report 85-4060.

Wilson, K. S., 1988, Chemical quality, benthic organisms, and sedimentation in streams draining coal-mined lands in Raccoon Creek Basin, Ohio, July 1984 through September 1986:

U. S. Geological Survey Water-Resources Investigations Report 88-4022. 


\section{MIAMI COUNTY:}

Norris, S. E., and Spieker, A. M., 1961, Geology and hydrology of the Piqua area (Miami County), Ohio: Ohio Department of Natural Resources, Division of Water Bulletin 1133-A.

\section{MONTGOMERY COUNTY:}

Bauer, D. P., 1968, Time of travel of water in the Great Miami River, Dayton to Cleves, Ohio:

U. S. Geological Survey Water-Supply Paper 546.

Dumouchelle, D. H., and de Roche, J. T., 1991, Lithologic, natural-gamma, grain-size, and well-construction data for Wright-Patterson Air Force Base, Ohio: U. S. Geological Survey Open-File Report 91-181.

Dumouchelle, D. H., 1992, Altitude of top of bedrock around Wright-Patterson Air Force Base, Ohio: U. S. Geological Survey Water-Resources Investigations Report 92-4072.

Fidler, R. E., 1975, Digital model simulation of the glacial-outwash aquifer at Dayton, Ohio: U. S. Geological Survey Water-Resources Investigations Report 18-75.

Norris, S. E., 1948, The bedrock surface and former drainage systems of Montgomery County, Ohio: Ohio Journal of Science, v. 48, no. 4, p. 146-150.

---1951 , The bedrock surface and the distribution of the consolidated rocks in Montgomery, Greene, Clark, and Madison Counties, Ohio: Ohio Journal of Science, v. 51, no. 1, p. 13-15.

---1959, Vertical leakage through till as a source of recharge to a buried-valley aquifer at Dayton (Montgomery County), Ohio: Ohio Department of Natural Resources, Division of Water Technical Report 2.

Norris, S. E., Cross, W. P., and Goldthwait, R. P., 1948, The water resources of Montgomery County, Ohio: Ohio Water Resources Board Bulletin 12.

Norris, S. E., and Spieker, A. M., 1966, Ground-water resources of the Dayton area (Montgomery County), Ohio: U. S. Geological Survey Water-Supply Paper 1808.

Schalk, C. W., 1992, Ground-water levels in the vicinity of Wright-Patterson Air Force Base, Ohio, October-December, 1987: U. S. Geological Survey Water-Resources Investigations Report 92-4022.

\section{MORROW COUNTY:}

Mayo, R. I., and Mangus, J. P., 1989, Flood of July 1-2, 1987, in North-Central Ohio: U. S. Geological Survey Open-File Report 89-376.

\section{MUSKINGUM COUNTY:}

Cunningham, W. L., and Jones, R. L., 1990, Long-term effects of surface coal mining on ground-water levels and quality in two small watersheds in eastern Ohio:

U. S. Geological Survey Water-Resources Investigations Report 90-4136.

Edelen, G. W., Jr., Ruggles, F. H., Jr., and Cross, W. P., 1964, Floods at Zanesville (Muskingum County), Ohio: U. S. Geological Survey Hydrologic Investigations Atlas 46.

Eberle, Michael, and Razem, A. C., 1985, Effects of surface coal mining and reclamation on ground water in small watersheds in the Allegheny Plateau, Ohio: U. S. Geological Survey Water-Resources Investigations Report 85-4205.

Helgesen, J. O., and Razem, A. C., 1981, Ground-water hydrology of strip-mine areas in eastern Ohio (Conditions during mining of two watersheds in Coshocton and Muskingum Counties): U. S. Geological Survey Open-File Report 81-913. 


\section{PICKAWAY COUNTY:}

Bartlett, W. P., Jr., and Sherwood, J. M., 1984, Flood-profile analysis, Big Darby Creek at State Route 762, Orient, Ohio: U. S. Geological Survey Water-Resources Investigations Report 84-4276.

Edelen, G. W., Jr., Ruggles, F. H., Jr., and Cross, W. P., 1964, Floods at Circleville (Pickaway County), Ohio: U. S. Geological Survey Hydrologic Investigations Atlas 48.

Norris, S. E., 1975, The ground-water situation in the Circleville area (Pickaway County), south-central Ohio: Ohio Department of Natural Resources Division of Geological Survey Report of Investigations 96.

\section{PIKE COUNTY:}

Norris, S. E., and Fidler, R. E., 1965, Relation of permeability to particle size in a glacial outwash aquifer at Piketon, Ohio: U. S. Geological Survey Professional Paper 525-D.

Norris, S. E., and Fidler, R. E., 1966, Use of type curves developed from electric analog studies of unconfined flow to determine the vertical permeability of an aquifer at Piketon (Pike County), Ohio: Ground Water, v. 4, no. 3, p. 43-48.

Norris, S. E., and Fidler, R. E., 1966, Effect of sampling and testing methods on computed hydraulic properties of glacial outwash at Piketon, Ohio: U. S. Geological Survey Professional Paper 550-D.

Norris, S. E., and Fidler, R. E., 1969, Hydrogeology of the Scioto River valley near Piketon (Pike County), Ohio: U. S. Geological Survey Water-Supply Paper 1872.

\section{PORTAGE COUNTY:}

Eberts, S. M., 1991, Geohydrology and water quality in northern Portage County, Ohio, in relation to deep-well brine injection: U. S. Geological Survey Water-Resources Investigations Report 90-4158.

Winslow, J. D., and White, G. W., 1966, Geology and ground-water resources of Portage County, Ohio: U. S. Geological Survey Professional Paper 511.

\section{PUTNAM COUNTY:}

Webber, E. E., 1982, Flood of June 13-15, 1981, in the Blanchard River basin, northwestern Ohio: U. S. Geological Survey Water-Resources Investigations Report 82-4044.

\section{RICHLAND COUNTY:}

Mayo, R. I., and Mangus, J. P., 1989, Flood of July 1-2, 1987, in North-Central Ohio: U. S. Geological Survey Open-File Report 89-376.

Stabler, Herman, 1906, Stream pollution by acid-iron waste, a report based on investigations made at Shelby, Ohio: U. S. Geological Survey Water-Supply Paper 186.

\section{ROSS COUNTY:}

Edelen, G. W., Jr., Ruggles, F. H., Jr., and Cross, W. P., 1964, Floods at Chillicothe (Ross County), Ohio: U. S. Geological Survey Hydrologic Investigations Atlas 45.

Mayo, R. I., and Bartlett, W. P., Jr., 1981, Hydraulic analysis, Paint Creek at State Route 772, Chillicothe, Ohio: U. S. Geological Survey Open-File Report 81-350. 


\section{SANDUSKY COUNTY:}

Breen, K. J., 1989, Potentiometric-surface map of the carbonate aquifer in Silurian and Devonian rocks, Lucas, Sandusky, and Wood Counties, northwestern Ohio, July, 1986:

U. S. Geological Survey Water-Resources Investigations Report 88-4144.

Breen, K. J., and Dumouchelle, D. H., 1992, Geohydrology and quality of water in Lucas, Sandusky, and Wood Counties, northwestern Ohio: U. S. Geological Survey Water-Resources Investigations Report 91-4024.

Edelen, G. W., Jr., Ruggles, F. H., Jr., and Cross, W. P., 1962, Floods at Fremont (Sandusky County), Ohio: U. S. Geological Survey Hydrologic Investigations Atlas 47.

Westfall, A. O., 1976, Time of travel of solutes in selected reaches of the Sandusky River basin, Ohio, 1972 and 1973: U. S. Geological Survey Water-Resources Investigations Report 76-50.

\section{SENECA COUNTY:}

Westfall, A. O., 1976, Time of travel of solutes in selected reaches of the Sandusky River Basin, Ohio, 1972 and 1973: U. S. Geological Survey Water-Resources Investigations Report 76-50.

\section{STARK COUNTY:}

Bair, E. S., and Norris, S. E., 1989, Ground-water levels and flow near the Industrial Excess Landfill, Uniontown, Ohio: U. S. Geological Survey Open-File Report 89-272.

Edelen, G. W., Jr., Somers, W. P., and Cross, W. P., 1962, Floods at Canton (Stark County), Ohio: U. S. Geological Survey Hydrologic Investigations Atlas 50.

Schaefer, E. J., White, G. W., and Van Tuyl, D. W., 1946, The ground-water resources of the glacial deposits in the vicinity of Canton (Stark County), Ohio: Ohio Water Resources Board Bulletin 3.

Westfall, A. O., and Webber, E. E., 1977, Time of travel of solutes in the Tuscarawas River Basin, Ohio, August and September 1974: U. S. Geological Survey Water-Resources Investigations Report 77-23.

\section{SUMMIT COUNTY:}

Edelen, G. W., Jr., Ruggles, F. H., Jr., and Cross, W. P., 1962, Floods at Barberton (Summit County), Ohio: U. S. Geological Survey Hydrologic Investigations Atlas 49.

Smith, R. C., and White, G. W., 1953, The ground-water resources of Summit County, Ohio:

Ohio Department of Natural Resources, Division of Water Bulletin 27.

Westfall, A. O., and Webber, E. E., 1977, Time of travel of solutes in the Tuscarawas River basin, Ohio, August and September 1974: U. S. Geological Survey Water-Resources Investigations Report 77-23.

\section{TRUMBULL COUNTY:}

Edelen, G. W., Jr., Ruggles, F. H., Jr., and Cross, W. P., 1963, Floods at Warren (Trumbull County), Ohio: U. S. Geological Survey Hydrologic Investigations Atlas 51.

\section{TUSCARAWAS COUNTY:}

Cummins, J. W., and Sanderson, E. E., 1947, The water resources of Tuscarawas County, Ohio: Ohio Water Resources Board Bulletin 6. 


\section{TUSCARAWAS COUNTY-Continued:}

Westfall, A. O., and Webber, E. E., 1977, Time of travel of solutes in the Tuscarawas River Basin, Ohio, August, and September 1974: U. S. Geological Survey Water-Resources Investigations Report 77-23.

\section{UNION COUNTY:}

Wilson, K. S., 1987, Ground-water flow and water quality in northeastern Union County, Ohio: U. S. Geological Survey Water-Resources Investigations Report 87-4083.

\section{VINTON COUNTY:}

Nichols, V. E., 1982, Drift mine reclamation in Big Four Hollow near Lake Hope, Ohio-An overview of preliminary data, in Proceedings, Abandoned Mine Reclamation Symposium, St. Clairsville, Ohio, November 3-5, 1982: Soil Conservation Society of America, All-Ohio Chapter, p. 16/1-16/9.

Nichols, V. E., 1983, Drift mine reclamation in Big Four Hollow near Lake Hope, Ohio-A preliminary data report: U. S. Geological Survey Open-File Report 83-217.

Nichols, V. E., 1985, Evaluation of the effects of coal-mine reclamation on water quality in Big Four Hollow near Lake Hope, southeastern Ohio: U. S. Geological Survey Water-Resources Investigations Report 85-4197.

Norris, S. E., and Mayer, G. C., 1982, Water resources of the Black Hand Sandstone Member of the Cuyahoga Formation and associated aquifers of Mississippian age in southeastern Ohio: U. S. Geological Survey Open-File Report 82-170.

Wilson, K. S., 1985, Surface-water quality of coal-mine lands in Raccoon Creek Basin, Ohio: U. S. Geological Survey Water-Resources Investigations Report 85-4060.

Wilson, K. S., 1988, Chemical quality, benthic organisms, and sedimentation in streams draining coal-mined lands in Raccoon Creek Basin, Ohio, July 1984 through September 1986: U. S. Geological Survey Water-Resources Investigations Report 88-4022.

\section{WAYNE COUNTY:}

Webber, E. E., and Mayo, R. I., 1970, Flood of July 5, 1969, in the vicinity of Wooster (Wayne County), Ohio: unnumbered U. S. Geological Survey Open-File Report.

\section{WILLIAMS COUNTY:}

Coen, A. W., III, 1989, Ground-water resources of Williams County, Ohio, 1984-1986:

U. S. Geological Survey Water-Resources Investigations Report 89-4020.

\section{WOOD COUNTY:}

Breen, K. J., 1989, Potentiometric-surface map of the carbonate aquifer in Silurian and Devonian rocks in Lucas, Sandusky, and Wood Counties, northwestern Ohio, July 1986:

U. S. Geological Survey Water-Resources Investigations Report 88-4144.

Breen, K. J., and Dumouchelle, D. H., 1991, Geohydrology and quality of water in Lucas, Sandusky, and Wood Counties, northwestern Ohio: U. S. Geological Survey Water-Resources Investigations Report 91-4024. 


\section{WOOD COUNTY-Continued:}

de Roche, J. T., and Breen, K. J., 1989, Hydrogeology and water quality near a solid- and hazardous-waste landfill, Northwood, Ohio: U. S. Geological Survey Water-Resources Investigations Report 88-4093.

\section{WYANDOT COUNTY:}

Webber, E. E., 1982, Flood of June 13-15, 1981, in the Blanchard River Basin, northwestern Ohio:U. S. Geological Survey Water-Resources Investigations Report 82-4044.

Westfall, A. O., 1976, Time of travel of solutes in selected reaches of the Sandusky River Basin, Ohio, 1972 and 1973: U. S. Geological Survey Water-Resources Investigations Report 76-50.

\section{OHIO:}

Angelo, C. G., and Youger, J. D., 1985, Chemical and biological quality of selected lakes in Ohio: U. S. Geological Survey Open-File Report 84-249.

Anttila, P. W., 1970, A proposed streamflow program for Ohio: unnumbered U. S. Geological Survey Open-File Report.

Anttila, P. W., and Tobin, R. L., 1978, Fluvial sediment in Ohio: U. S. Geological Survey Water-Supply Paper 2045.

Archer, R. J., 1960, Sediment discharge of Ohio streams during floods of January-February 1959: Ohio Department of Natural Resources, Division of Water Miscellaneous Report 13.

Bair, E. S., Sheets, R. A., and Eberts, S. M., 1990, Particle-tracking analysis of flow paths and traveltimes from hypothetical spill sites within the capture area of a wellfield: Ground Water v. 28, no. 6, November-December 1990.

Bauer, D. P., 1968, Time of travel of water in the Great Miami River, Dayton to Cleves, Ohio: U. S. Geological Survey Circular 546.

Beaber, H. C., and Rostvedt, J. O., 1965, Floods of March 1964 along the Ohio River: U. S. Geological Survey Water-Supply Paper 1840-A.

Bednar, G. A., Collier, C. R., and Cross, W. P., 1968, Analysis of water quality of the Mahoning River in Ohio: U. S. Geological Survey Water-Supply Paper 1859-C.

Biesecker, J. E., and George, J. R., 1966, Stream quality in Appalachia as related to coal-mine drainage: U. S. Geological Survey Circular 526.

Bloyd, R. M., Jr., 1974, Summary appraisals of the Nation's ground-water resources-Ohio Region: U. S. Geological Survey Professional Paper 813-A.

Breen, K. J., 1988, Factors affecting major-ion chemistry of ground water in the Lockport Dolomite of northwestern Ohio, in 33rd Annual Midwest Ground Water Conference, Program with Abstracts: p. 2.

Breen, K. J., 1988, Geochemistry of the stratified-drift aquifer in Killbuck Creek Valley west of Wooster, Ohio, in Randall, A. D., and Johnson, A. I., eds., Regional aquifer systems of the United States-the northeast glacial aquifers: American Water Resources Association Monograph Series No. 11, p. 105-131.

Breen, K. J., Angelo, C. G., Masters, R. W., and Sedam, A. C., 1985, Chemical and isotopic characteristics of brines from three oil- and gas-producing formations in eastern Ohio, with applications to the geochemical tracing of brine sources: U. S. Geological Survey Water-Resources Investigations Report 84-4314. 


\section{OHIO-Continued:}

Bugliosi, E. F., 1990, Plan of study for the Ohio-Indiana carbonate-bedrock and glacial-aquifer system: U. S. Geological Survey Open-File Report 90-151.

Camp, L. D., 1988, Water-resources activities in Ohio, 1988: U. S. Geological Survey Open-File Report 88-196 (Water Fact Sheet).

Childress, C. J. Oblinger, 1984, Literature review and need for additional study of surface-water quality in the Cuyahoga National Recreation Area: U. S. Geological Survey Open-File Report 84-619.

Childress, C. J. Oblinger, 1985, Classification of stream basins in southeastern Ohio according to extent of surface coal mining: U. S. Geological Survey Water-Resources Investigations Report 84-4212.

Childress, C. J. Oblinger, Chaney, T. H., Myers, D. M., Norris, J. M., and Hren, Janet, 1989, Water-quality data-collection activities in Colorado and Ohio- Phase II-evaluation of 1984 field and laboratory quality-assurance practices: U. S. Geological Survey Water-Supply Paper 2295-B.

Cross, W. P., 1949, The relation of geology to dry-weather stream flow in Ohio: Transactions of the American Geophysical Union, v. 30, no. 4, p. 563-566.

---1961, Floods of January-February 1959 in Ohio: Ohio Department of Natural Resources, Division of Water Bulletin 35.

---1963, Low-flow frequencies and storage requirements for selected Ohio streams: Ohio Department of Natural Resources, Division of Water Bulletin 37.

---1964, Floods of March 1963 in Ohio: Ohio Department of Natural Resources, Division of Water Bulletin 38.

---1964, Floods of March 1964 in Ohio: Ohio Department of Natural Resources, Division of Water Bulletin 39.

---1965, Low-flow frequency and storage-requirement indices for Ohio streams: Ohio Department of Natural Resources, Division of Water Bulletin 40.

---1967, Drainage areas of Ohio streams, supplement to Gazetteer of Ohio steams: Ohio Department of Natural Resources, Division of Water Inventory Report 12a.

---1968, Flow duration of Ohio streams, based on gaging-station records through 1965:

Ohio Department of Natural Resources, Division of Water Bulletin 42.

Cross, W. P., and Brooks, H. P., 1959, Floods of January-February 1959 in Ohio:

U. S. Geological Survey Circular 418.

Cross, W. P., and Hedges, R. E., 1959, Flow duration of Ohio streams: Ohio Department of Natural Resources, Division of Water Bulletin 31.

Cross, W. P., and Mayo, R. I., 1969, Floods in Ohio, magnitude and frequency-Supplement to Bulletin 32 (Cross and Webber, 1959): Ohio Department of Natural Resources, Division of Water Bulletin 43.

Cross, W. P., Schroeder, M. E., and Norris, S. E., 1952, Water resources of the Mahoning River basin, Ohio, with special reference to the Youngstown area: U. S. Geological Survey Circular 177.

Cross, W. P., and Webber, E. E., 1950, Ohio streamflow characteristics--part 2, water supply and storage requirements: Ohio Department of Natural Resources, Division of Water Bulletin 13. 


\section{OHIO-Continued:}

Cross, W. P., and Webber, E. E.,1959, Floods in Ohio-Magnitude and frequency: Ohio Department of Natural Resources, Division of Water Bulletin 32.

Crouch, T. M., Collins, H. R., and Helgesen, J. O., 1980, Abandoned subsurface coal mines as a source of water for coal conversion in eastern Ohio: Ohio Department of Natural Resources Division of Geological Survey Report of Investigations 118.

Deutsch, Morris, Dove, G. D., Jordan, P. R., and Wallace, J. C., 1967, Ground-water distribution and potential in the Ohio River Basin: U. S. Army Corps of Engineers, Ohio River Basin Comprehensive Survey, v. VII, app. E-Ground Water.

Deutsch, Morris, and Wallace, J. C., 1966, Six illustrations showing water-resources information on Maumee River Basin: unnumbered U. S. Geological Survey Open-File Report.

Dove, G. D., 1960, Drainage of the Teays-stage Mount Vernon and Cambridge Rivers: Ohio Journal of Science, v. 60, no. 2, p. 122-124.

---1962, Ground-water resources, in Geology of Fairfield County: Ohio Department of Natural Resources Division of Geological Survey Bulletin 60.

Eberle, Michael, and McClure, J. A., 1984, Water use in Ohio, 1980: U. S. Geological Survey Water-Resources Investigations Report 84-4024.

Eberle, Michael, and McClure, J. A., 1986, Offstrean water withdrawals by thermoelectric powerplants and public water supplies in Ohio, 1982: U. S. Geological Survey Open-File Report 85-639.

Eberle, Michael, and Razem, A. C., 1985, Effects of surface coal mining and reclamation on ground water in small watersheds in the Allegheny Plateau, Ohio: U. S. Geological Survey Water-Resources Investigations Report 85-4205.

Eberts, S. M., and Bair, E. S., 1990, Simulated effects of quarry dewatering near a municipal well field: Ground Water, v. 28, no. 1, p. 37-47.

Engelke, M. J., Jr., Roth, D. K., and others, 1981, Hydrology of Area 7, Eastern Coal Province, Ohio: U. S. Geological Survey Open-File Report 81-815.

Evans, K. F., 1977, Water quality of the glacial-outwash aquifer in the Great Miami River Basin, Ohio: U. S. Geological Survey Water-Resources Investigations Report 77-76.

Federal Emergency Management Agency, Flood insurance studies (published for selected municipalities and for unincorporated areas of counties).

Ficke, J. F., and Hawkinson, R. O., 1975, The National Stream Quality Accounting Network (NASQAN)-Some questions and answers: U. S. Geological Survey Circular 719.

Friel, E. A., Ehlke, T. A., Hobba, W. A., Jr., Ward, S. M., and Shultz, R. A., 1987, Hydrology of Area 8, eastern coal province, West Virginia and Ohio: U. S. Geological Survey Open-File Report 84-463.

Goldthwait, R. P., White, G. W., and Forsyth, J. L., 1961 (revised in part, 1967), Glacial map of Ohio: U. S. Geological Survey Miscellaneous Investigations Series 316.

Gordon, A. B., and Katzenbach, M.S., 1983, Guidelines for use of water-quality monitors: U. S. Geological Survey Open-File Report 83-681.

Grover, N. C., 1937, The floods of March 1936-Part 3, Potomac, James, and upper Ohio Rivers with a section on the weather associated with the floods of March 1936, by Stephen Lichtblau, U. S. Weather Bureau: U. S. Geological Survey Water-Supply Paper 800. 


\section{OHIO-Continued:}

Grover, N. C., 1938, Floods of Ohio and Mississippi Rivers, January-February 1937, with a section on flood deposits of the Ohio River, January-February 1937, by G. R. Mansfield: U. S. Geological Survey Water-Supply Paper 838.

Hamon, W. R., Bonta, J. V., Haghiri, Faz, and Helgesen, J. O., 1979, Research on the hydrology and water-quality of watersheds subjected to surface mining, I-Premining hydrology and water quality conditions, in Coal Conferences and Expo V, Symposium on Surface Coal Mining and Reclamation, Louisville, Ky.: Coal Age, p. 70-98.

Hamon, W. R., Haghiri, Faz, and Knochenmus, Darwin, 1977, Research on the hydrology and water quality of watersheds subjected to surface mining, in Fifth Symposium on Surface Mining and Reclamation: Louisville, Ky., National Coal Association and Bituminous Coal Research, Inc., p. 37-40.

Hathaway, R. M., and Eberle, Michael, 1981, Water use in Ohio, 1975: U. S. Geological Survey Water-Resources Investigations Report 81-17.

Heath, R. C., 1983, Basic ground-water hydrology: U. S. Geological Survey Water-Supply Paper 2220.

Helgesen, J. O., Larson, S. P., and Razem, A. C., 1982, Model modifications for simulation of flow through stratified rocks in eastern Ohio: U. S. Geological Survey Water-Resources Investigations Report 82-4019.

Helsel, D. R., and Pfaff, C. L., 1982, Surface-water quality in coal regions of Ohio, in Proceedings, Abandoned Mine Reclamation Symposium, St. Clairsville, Ohio, November 3-5, 1982: Soil Conservation Society of America, All-Ohio Chapter, p. $2 / 1-2 / 7$.

Hendricks, E. L., 1964, Floods of January-February 1959 in Ohio and adjacent states: U. S. Geological Survey Water-Supply Paper 1750-A.

Hindall, S. M., 1986, Water-resources activities in Ohio: U. S. Geological Survey Open-File Report 86-308.

---1988, Water fact sheet: U. S. Geological Survey ground-water studies in Ohio:

U. S. Geological Survey Open-File Report 88-128.

---1989 , Current water-resources activities in Ohio, 1989: U. S. Geological Survey Open-File Report 89-58.

--1989, Summary of fluvial-sediment studies in Ohio, through 1987: U. S. Geological Survey Water-Resources Investigations Report 89-4066.

---1990, Trends in fluvial sediment discharge in Ohio: Journal of Soil and Water Conservation, v. 46, no. 4, p. 311-313.

Hindall, S. M., and Camp, L. D., 1991, Current water-resources activities in Ohio, 1991: U. S. Geological Survey Open-File Report 91-96.

Hindall, S. M., and Eberle, C. M., 1992, Continuous-record networks for collection of hydrologic data in Ohio: U. S. Geological Survey Open-File Report 92-152 (Water Fact Sheet).

Horton, A. H., and Jackson, H. J., 1913, The Ohio valley flood of March-April, 1913, including comparisons with some earlier floods: U. S. Geological Survey Water-Supply Paper 334.

Hren, Janet, 1984, Determination of reaeration coefficients for Ohio streams: U. S. Geological Survey Water-Resources Investigations Report 84-4139. 


\section{OHIO-Continued:}

Hren, Janet, Chaney, T. H., Norris, J. M., and Childress, C. J. Oblinger, 1987, Water-quality data-collection activities in Colorado and Ohio: Phase I-evaluation of 1984 programs and costs: U. S. Geological Survey Water-Supply Paper 2295-A.

Hren, Janet, Wilson, K. S., and Helsel, D. R., 1984, A statistical approach to evaluate the relation of coal mining, land reclamation, and surface-water quality in Ohio: U. S. Geological Survey Water-Resources Investigations Report 84-4117.

Hubble, J. H., and Collier, C. R., 1960, Quality of surface waters in Ohio, 1946-58: Ohio Department of Natural Resources, Division of Water Inventory Report 14.

Johnson, D. P., and Metzker, K. D., 1981, Low-flow characteristics of Ohio streams: U. S. Geological Survey Open-File Report 81-1195.

Jones, A. L., 1988, Geologic setting and water quality of selected basins in the active coalmining areas of Ohio, June 1985 through December 1986: U. S. Geological Survey Water-Resources Investigations Report 88-4084.

Kaser, Paul, and Harstine, L. J., 1965, Ground-water levels in Ohio, October 1959-September 1964: Ohio Department of Natural Resources, Division of Water Bulletin 41.

Katzenbach, M. S. 1988, Economic comparison of two types of automatic water-quality monitors: U. S. Geological Survey Water-Resources Investigations Report 87-4232.

Katzenbach, M. S., 1990, Comparison of accuracy and completeness of data obtained from three types of automatic water-quality monitors: U. S. Geological Survey Water-Resources Investigations Report 89-4198.

Koltun, G. F., and Schwartz, R. R., 1987, Multiple-regression equations for estimating low flows at ungaged stream sites in Ohio: U. S. Geological Survey Water-Resources Investigations Report 86-4354.

Koltun, G. F., and Roberts, J. W., 1990, Techniques for estimating flood-peak discharges of rural, unregulated streams in Ohio: U. S. Geological Survey Water-Resources Investigations Report 89-4126.

Kolva, J. R., 1985, Preliminary evaluation of magnitude and frequency of floods in selected small drainage basins in Ohio: U. S. Geological Survey Open-File Report 85-194.

Lamar, W. L., and Collier, C. R., 1956, Suspended sediment characteristics of Ohio streams: Journal of Soil and Water Conservation, v. 11, no. 5, p. 233-237.

Lamar, W. L., and Schroeder, M. E., 1951, Chemical character of surface waters in Ohio, 1946-50: Ohio Department of Natural Resources, Division of Water Bulletin 23.

Lewis, S. J., 1906, Quality of water in the upper Ohio River Basin and at Erie, Pa.: U. S. Geological Survey Water-Supply Paper 161.

Lloyd, O. B., Jr., and Davis, R. W., 1988, Preliminary hydrogeologic evaluation of the Cincinnati Arch region for underground high-level radioactive waste disposal, Indiana, Kentucky, and Ohio: U. S. Geological Survey Water-Resources lnvestigations Report 88-4098.

MacCary, L. M., 1971, Resistivity and neutron logging in Silurian dolomite of northwest Ohio, in Geological Survey Research 1971, U. S. Geological Survey Professional Paper 750-D, p. D190-D197.

MacKichan, K. A., 1951, Estimated use of water in the United States, 1950: U. S. Geological Survey Circular 115. 


\section{OHIO-Continued:}

MacKichan, K. A., 1957, Estimated use of water in the United States, 1955: U. S. Geological Survey Circular 398.

---1961, Estimated use of water in the United States, 1960: U. S. Geological Survey Circular 456.

Mayo, R. I., Webber, E. E., and Ellis, D. W., 1971, Floods of July 4-8, 1969, in north-central Ohio:

unnumbered U. S. Geological Survey Open-File Report.

Murray, C. R., 1968, Estimated use of water in the United States, 1965: U. S. Geological Survey Circular 556.

Murray, C. R., and Reeves, E. B., 1972, Estimated use of water in the United States, 1970: U. S. Geological Survey Circular 676.

Myers, D. N., 1991, A combined-network approach for compilation, evaluation, and analysis of precipitation-chemistry data for the Upper Ohio River Valley and Lower Great Lakes Region: U. S. Geological Survey Water-Resources Investigations Report.

Nichols, V. E., 1989, Withdrawal and distribution of water by public water supplies in Ohio, 1985: U. S. Geological Survey Open-File Report 89-423.

Norris, J. M., Hren, Janet, Myers, D. N., Chaney, T. H, and Childress, C. J. Oblinger, 1990, Waterquality data-collection activities in Colorado and Ohio: Phase III-Evaluation of existing data for use in assessing regional water-quality conditions and trends: U. S. Geological Survey Open-File Report 89-391.

Norris, S. E., 1957, Groundwater investigations-Problems faced by geologists in Ohio: Water Well Journa1, July 1957, p. 1-3.

---1957, Characteristics of limestone and dolomite aquifers in western Ohio: Journal of the American Water Works Association, v. 49, no. 4, p. 464-468.

---1959, Minford silt and ground water quality in western Ohio: Journal of the American Water Works Association, v. 51, no. 9, p. 1170-1174.

---1963, Permeability of glacial till: U. S. Geological Survey Professional Paper 450-E.

---1967, The ground-water situation in Ohio: Ohio Chamber of Commerce.

---1969, The ground-water situation in Ohio: Ground Water, v. 7, no. 5, p. 25-33.

---1970, The effect of stream discharge on streambed leakage to a glacial outwash aquifer, in U. S. Geological Survey Geological Survey Research 1970, p. D262-D265.

Norris, S. E.,1972, The use of gamma logs in determining the character of unconsolidated sediments and well construction features: Ground Water, v. 10, no. 6, p. 14-21.

---1974, Regional flow system and ground-water quality in western Ohio: U. S. Geological Survey Journals of Research, v. 2, no.5, p. 527-531.

---1975, Geological structure of near-surface rocks in western Ohio: Ohio Journal of Science, v. 75 , no. 5, p. 225-228.

Norris, S. E., 1976, Change in drawdown caused by enlarging a well in a dolomite aquifer: Ground Water, v. 14, no. 4, p. 191-193.

---1978, Hydrologic environment of the Silurian salt deposits in parts of Michigan, Ohio, and New York: U. S. Geological Survey Open-File Report 78-684.

---1983, Aquifer tests and well field performance, Scioto River Valley, Ohio, part I: Ground Water, v. 21 , no. 3 , p. 287-92. 


\section{OHIO-Continued:}

Norris, S. E., 1983, Aquifer tests and well field performance, Scioto River Valley, Ohio, part II: Ground Water, v. 21, no. 4, p. 438-44.

Norris, S. E., and Fidler, R. E., 1969, Correlation of carbonate rock units in northwest Ohio by natural gamma logging: U. S. Geological Survey Professional Paper 650-B.

--1971, Availability of ground water from limestone and dolomite aquifers in northwest Ohio and its relation to geologic structure, in Geological survey research 1971, U. S. Geological Survey Professional Paper 750-B, p. B229-B235.

---1971, Carbonate equilibria distribution and its relation to an area of high ground-water yield in northwest Ohio, in Geological survey research 1971, U. S. Geological Survey Professional Paper 750-C, p. C202-C206.

---1973, Availability of water from limestone and dolomite aquifers in southwest Ohio and the relation of water quality to the regional flow system: U. S. Geological Survey Water-Resources Investigations Report 17-73.

Norris, S. E., and Mayer, G. C., 1982, Water resources of the Black Hand Sandstone member of the Cuyahoga Formation and associated aquifers of Mississippian age in southeastern Ohio: U. S. Geological Survey Open-File Report 82-170.

Norris, S. E., and Spieker, A. M., 1962, Temperature-depth relations in wells as indicators of semiconfining beds in valley-train aquifers: U. S. Geological Survey Professional Paper 450-B.

Ohio Department of Natural Resources, Division of Water, 1970, Ground water for planning in northwest Ohio-A study of the carbonate rock aquifers: Ohio Department of Natural Resources, Division of Water Inventory Report 22.

Pfaff, C. L., Helsel, D. R., Johnson, D. P., and Angelo, C. G., 1981, Assessment of water quality in streams draining coal-producing areas in Ohio: U. S. Geological Survey Open-File Report 81-409.

Rau, J. L., 1969, Hydrogeology of the Berea and Cussewago Sandstones in northeastern Ohio: U. S. Geological Survey Hydrologic Investigations Atlas 341.

Razem, A. C., 1982, Comparisons of premining, mining, and postmining ground-water conditions in three small watersheds in eastern Ohio: Geological Society of America Abstracts with Programs, v. 15 , no. 7.

Razem, A. C., 1983, Ground-water monitoring of three small surface-mined watersheds in eastern Ohio (abstract): Ground Water Monitoring Review, v. 3, no. 1, p. 153.

Razem, A. C., and Helgesen, J. O., 1981, Preliminary observation of surface-mine impacts on ground water in two small watersheds in eastern Ohio (abstract), in Indiana Water Resources Second Annual Symposium, Spencer, Ind.

Razem, A. C., and Sedam, A. C., 1985, Ground-water quality and geochemistry of aquifers associated with coal in the Allegheny and Monongahela Formations, southeastern Ohio: U. S. Geological Survey Water-Resources Investigations Report 85-4034.

Roth, D. K., 1985, Estimating flood peaks from channel characteristics in Ohio: U. S. Geological Survey Water-Resources Investigations Report 85-4175.

Roth, D. K., and Cooper, S. C., 1984, Hydrology of Area 11, Eastern Coal Province, Ohio, Kentucky, and West Virginia: U. S. Geological Survey Open-File Report 84-233. 


\section{OHIO-Continued:}

Roth, D. K., Engelke, M. J., Jr., and others, 1981, Hydrology of Area 4, Eastern Coal Province, Pennsylvania, Ohio, and West Virginia: U. S. Geological Survey Open-File Report 81-343.

Schneider, W. J., 1957, Relation of geology to streamflow in the Upper Miami Basin: Ohio Journal of Science, v. 57, no. 1, p. 11-14.

Schneider, W. J., and others, 1965, Water resources of the Appalachian Region, Pennsylvania to Alabama: U. S. Geological Survey Hydrologic Investigation Atlas 198.

Schwartz, R. R., 1985, Low-flow data for selected partial-record stations in Ohio: U. S. Geological Survey Open-File Report 84-824.

Sedam, A. C., 1973, Hydrogeology of the Pottsville Formation in northeastern Ohio: U. S. Geological Survey Hydrologic Investigations Atlas 494.

Sedam, A. C., 1990, Geologic setting and water quality of selected basins in the active-coalmining areas of Ohio, 1987-88: U. S. Geological Survey Water-Resources Investigations Report 90-4109.

Sedam, A. C., and Stein, R. B., 1970, Saline ground-water resources of Ohio: U. S. Geological Survey Hydrologic Investigations Atlas 366.

Sheets, R. A., 1990, Selected geologic and hydrologic data for the regional carbonate-bedrock and glacial aquifers in western Ohio: U. S. Geological Survey Open-File Report 90-590.

Sheets, R. A., Bair, E. S., and Eberts, S. M., 1988, Determination of flow paths and traveltimes of contaminates from hypothetical spill sites surrounding a municipal well field, in 33rd Annual Midwest Ground Water Conference, Program with Abstracts: p. 20.

Sherwood, J. M., 1985, Preliminary report on a study to establish flood volumes of small rural streams in Ohio-Methods, site selection, and data base: U. S. Geological Survey Open-File Report 84-470.

---1986, Estimating peak discharges, flood volumes, and hydrograph shapes of small ungaged urban streams in Ohio: U. S. Geological Survey Water-Resources Investigations Report 86-4197.

---1986, Effects of urbanization on runoff from small drainage areas in Ohio:

U. S. Geological Survey Water-Resources Investigations Report 86-4197.

--1989, Estimation of volume-duration-frequency relations of small rural streams in Ohio: Preprint for Transportation Research Board, 68th Annual Meeting, January 22-26, 1989, Washington, D. C.

Shindel, H. L., and Bartlett, W. P., Jr., 1985, Cost effectiveness of the stream-gaging program in Ohio: U. S. Geological Survey Water-Resources Investigations Report 85-4072.

Smith, R. C., Doll, W. L., and Stratton, Garland, 1955, Water resources of the WheelingSteubenville area, West Virginia and Ohio: U. S. Geological Survey Bulletin 340.

Spieker, A. M., 1968, Ground-water hydrology and geology of the lower Great Miami River valley, Ohio: U. S. Geological Survey Professional Paper 605-A.

-.-1968, Future developments of the ground-water resources in the lower Great Miami River valley, Ohio-Problems and alternative solutions: U. S. Geological Survey Professional Paper 605-D.

Strobel, M. L., and Bugliosi, E. F., 1991, Areal extent hydrogeologic characteristics, and possible origins of the carbonate rock Newburg zone (Middle-Upper Silurian) in Ohio: Ohio Journal of Science, v. 91, no. (5), p. 209-215. 


\section{OHIO-Continued:}

Tobin, R. L., and Youger, J. D., 1977, Limnology of selected lakes in Ohio, 1975:

U. S. Geological Survey Water-Resources Investigations Report 77-105.

Tobin, R. L., and Youger, J. D., 1979, Chemical and biological quality of selected lakes in Ohio, 1976 and 1977: U. S. Geological Survey Water-Resources Investigations Report 78-109.

U. S. Geological Survey, 1961-64, Surface-water records of Ohio (published annually): unnumbered U. S. Geological Survey Open-File Report.

---1964, Water-quality records of Ohio: unnumbered U. S. Geological Survey Open-File Report.

---1965-74, Water-resources data for Ohio-Part 1, Surface-water records; Part 2, Waterquality records (published annually): unnumbered U. S. Geological Survey Open-File Report.

U. S. Geological Survey, 1988, Hydrologic unit map of Ohio. An overprint of the 1:500,000 scale state base map. No contours. Sheet is 36 by 40 inches. 1951 base, drainage modified in 1988 . This map and accompanying table show hydrologic units that are basically hydrographic in nature. The Cataloging Units shown supplant those previously used by the U. S. Geological Survey in its Catalog of Information on Water Data (1966-72).

U. S. Geological Survey, Water resources data, Ohio: U. S. Geological Survey Water-Data Reports (published annually).

U. S. Geological Survey, 1984, National water summary 1983: Hydrologic events and issues: U. S. Geological Survey Water-Supply Paper 2250.

---1985, National water summary 1984 -Hydrologic events, selected water-quality trends, and ground-water resources: U. S. Geological Survey Water-Supply Paper 2275.

---1986, National water summary 1985-Hydrologic events and surface-water resources:

U. S. Geological Survey Water-Supply Paper 2300.

---1987, National water summary 1986-Hydrologic events and ground-water quality:

U. S. Geological Survey Water-Supply Paper 2325.

---1988, National water summary 1987-Hydrologic events and water supply and use:

U. S. Geological Survey Water-Supply Paper 2350.

---1990, National water summary 1988-89-Hydrologic events and floods and droughts:

U. S. Geological Survey Water-Supply Paper2375.

Veley, R. J., 1992, Advantages and limitations of water-supply alternatives: U. S. Geological Survey Open-File Report 92-119 (Water Fact Sheet).

Veley, R. J., 1993, Estimated water use in Ohio, 1990: U. S. Geological Survey Open-File Report 93-72 (Water Fact Sheet)

Watkins, J. S., and Spieker, A. M., 1971, Seismic refraction survey of Pleistocene drainage channels in the lower Great Miami River valley, Ohio: U. S. Geological Survey Professional Paper 605-B.

Webber, E. E., 1971, Low-flow study for southwest Ohio streams: unnumbered U. S. Geological Survey Open-File Report.

Webber, E. E., and Bartlett, W. P., Jr., 1976, Floods in Ohio-magnitude and frequency: U. S. Geological Survey Open-File Report 76-768.

Webber, E. E., and Roberts, J. W., 1981, Floodflow characteristics related to channel geometry in Ohio: U. S. Geological Survey Open-File Report 81-1105.

Weist, W. G., Jr., 1978, Summary appraisal of the Nation's ground-water resources-Great Lake Region: U. S. Geological Survey Professional Paper 813-J. 


\section{OHIO-Continued:}

Westover, Susan, and Eberle, Michael, 1987, Overview of surface-water quality in Ohio's coal region: U. S. Geological Survey Water-Resources Investigations Report 84-4061.

White, G. W., 1951, Illinoian and Wisconsin drift of the southern part of the Grand River lobe in eastern Ohio: Geological Survey of America Bulletin, v. 62, no. 9, p. 967-977.

Wyrick, G. G., 1968, Ground-water resources of the Appalachian region: U. S. Geological Survey Hydrologic Investigations Atlas 295.

Youngquist, C. V., and Langbein, W. B., 1941, Flood of August 1935 in the Muskingum River Basin, Ohio: U. S. Geological Survey Water-Supply Paper 869. 

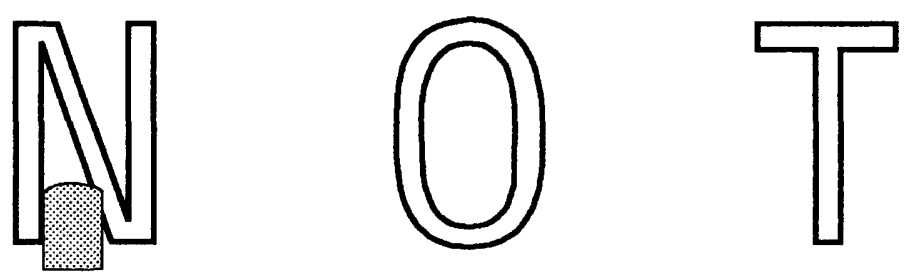
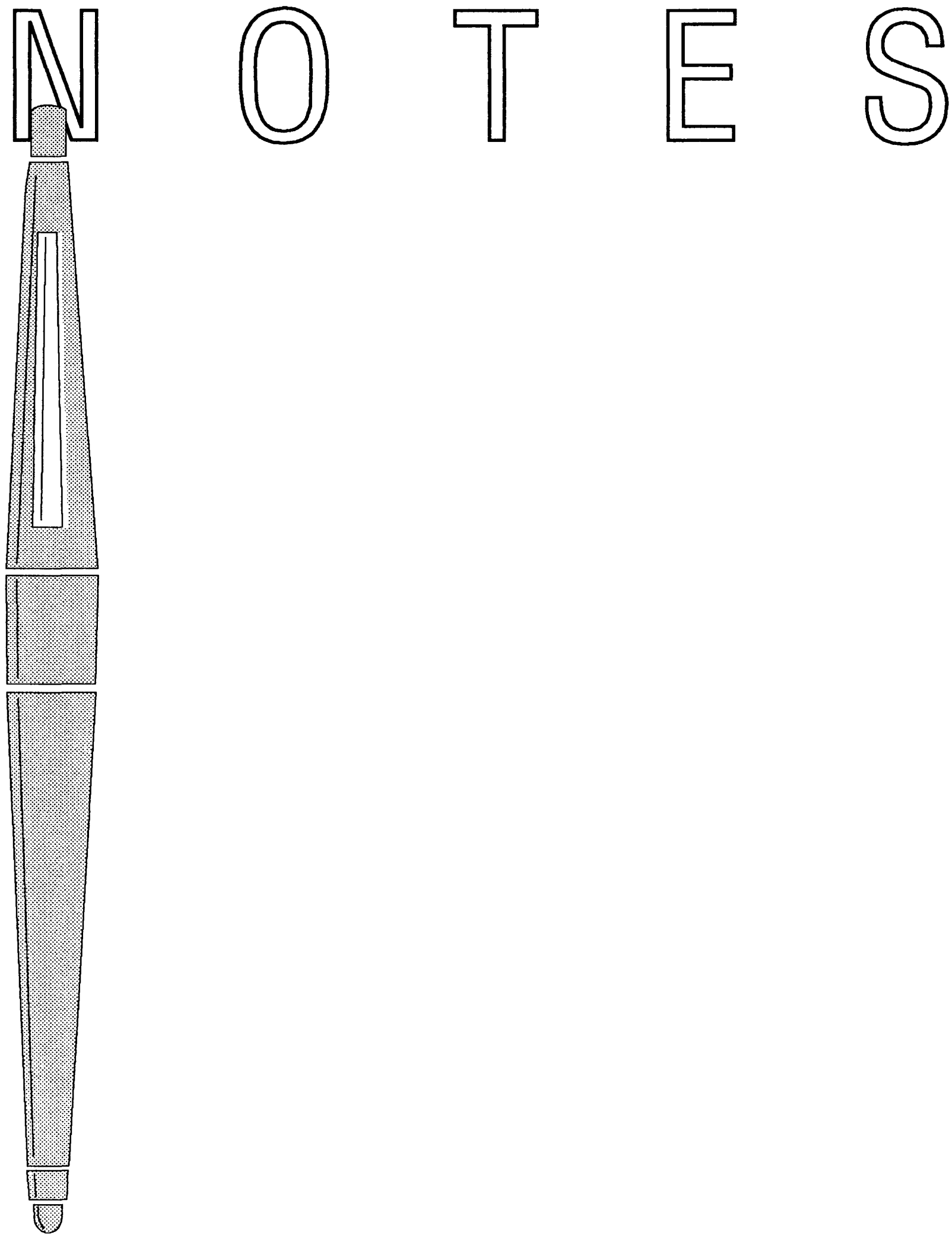

Current Water-Resources Activities in Ohio, 1993-94 - Page 80 

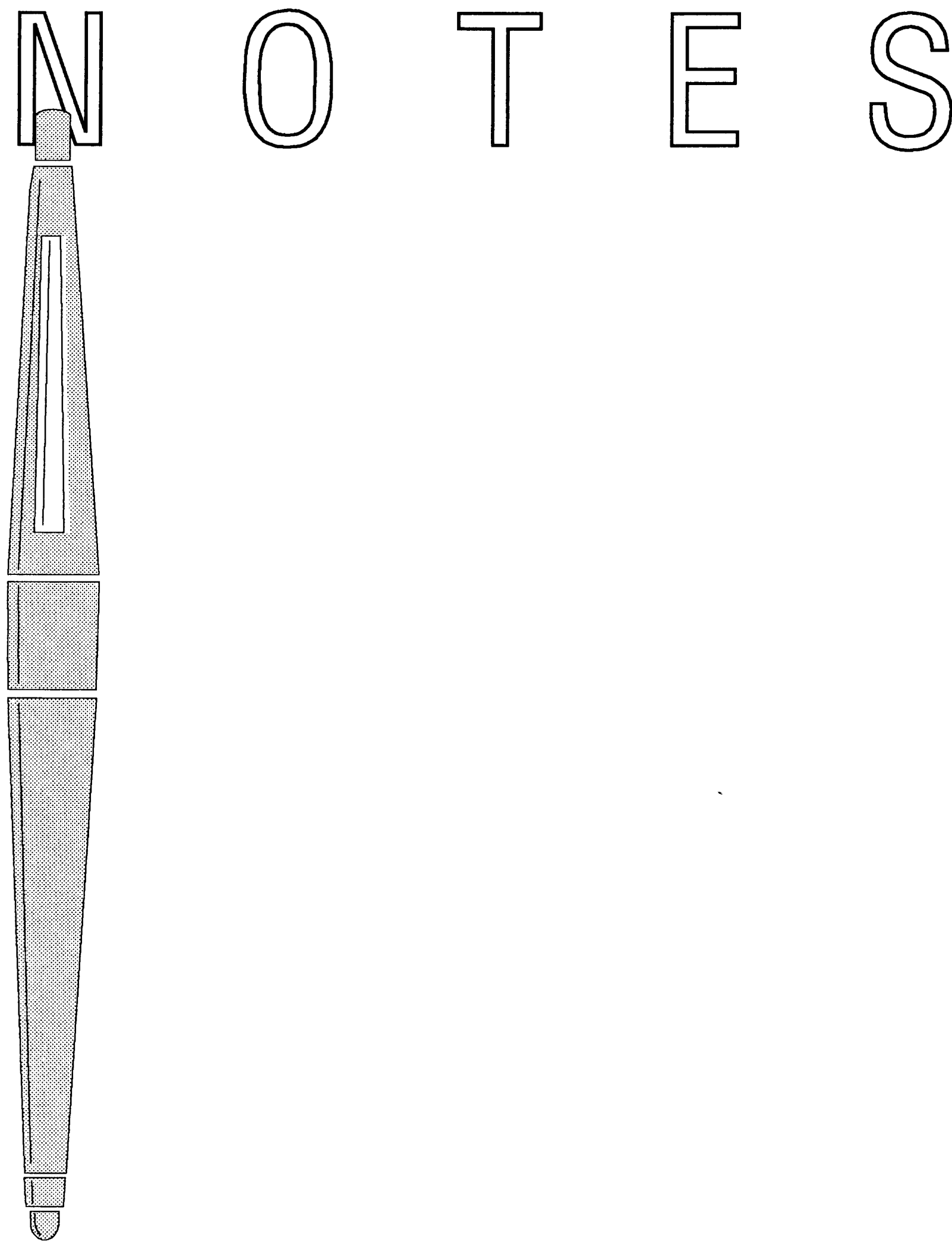

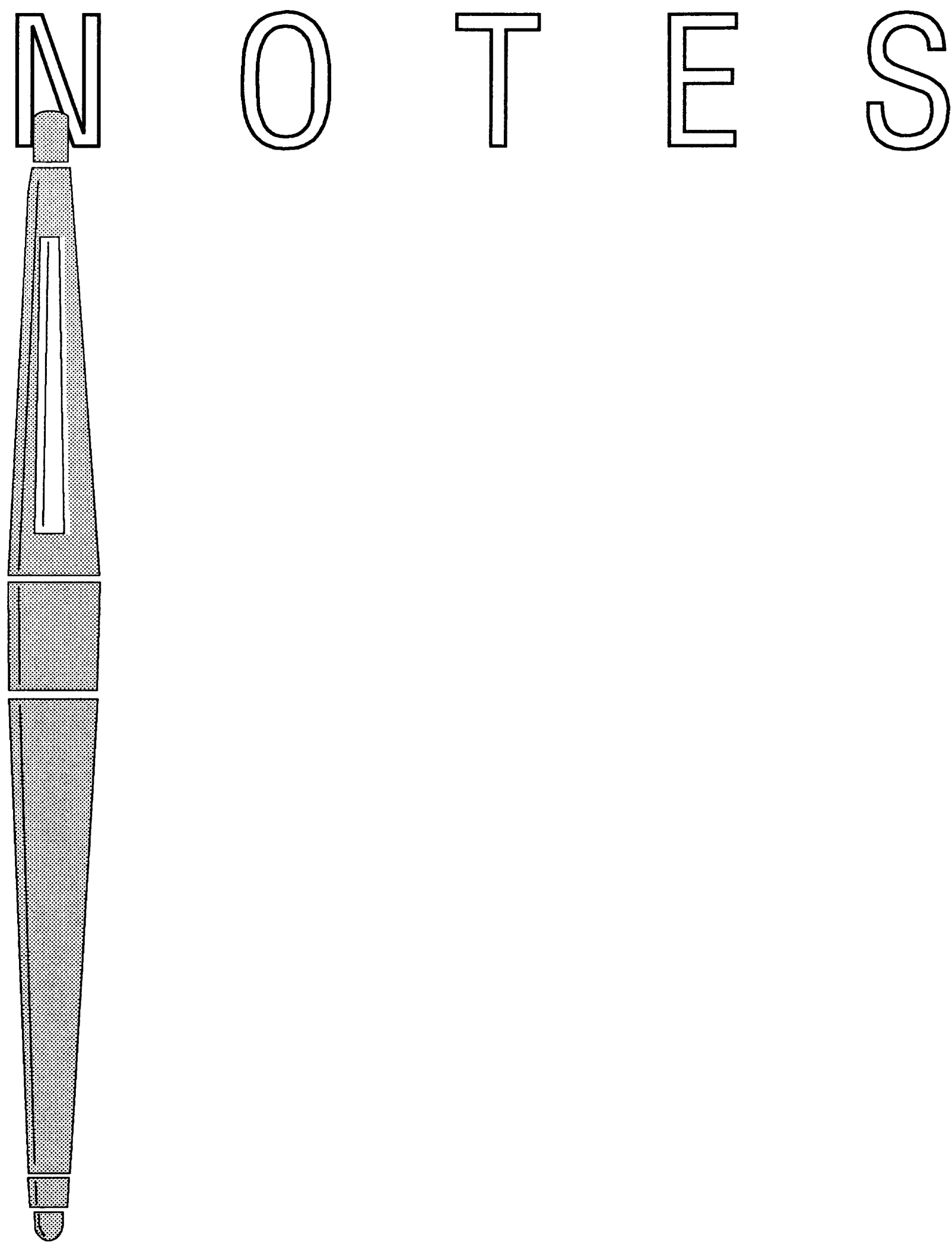